\author{
Universidade de Brasília \\ Instituto de Ciências Biológicas \\ Programa de Pós-graduação em Nanociência e Nanobiotecnologia
}

Mateus Candeia Gianizeli

Eficácia da Alumínio-Cloro-Ftalocianina associada a nanopartículas de magnetita na Terapia Fotodinâmica: um estudo in vitro

Brasília, DF

2015 


\author{
Universidade de Brasília \\ Instituto de Ciências Biológicas \\ Programa de Pós-graduação em Nanociência e Nanobiotecnologia
}

Mateus Candeia Gianizeli

\title{
EFICÁCIA DA ALUMÍNIO-CLORO-FTALOCIANINA ASSOCIADA A NANOPARTÍCULAS DE MAGNETITA NA TERAPIA FOTODINÂMICA: UM ESTUDO IN VITRO
}

Dissertação apresentada ao programa de Pós-graduação em Nanociência e Nanobiotecnologia do Instituto de Ciências Biológicas da Universidade de Brasília, como parte integrante dos requisitos para a obtenção do título de Mestre em Nanociência e Nanobiotecnologia.

Orientador (a): Maria de Fátima Menezes Almeida Santos

Coorientador: Ricardo Bentes de Azevedo

$$
\text { Brasília - DF }
$$


Dissertação de Mestrado

Mateus Candeia Gianizeli

Título:

\section{${ }^{66}$ Eficácia do Alumínio-Cloro Ftalocianina associada à nanopartículas de magnetita na Terapia Fotodinâmica: Um estudo in vitro"}

Comissão Examinadora:

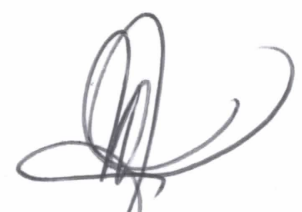

Prof. Dra. Maria de Fátina Menezes Almeida Santos

Presidente

UnB

Ana Paula Dios Riburg

Prof. Dra. Ana Paula Dias Ribeiro

Membro Titular Interno não vinculado ao

Programa

$U n B$

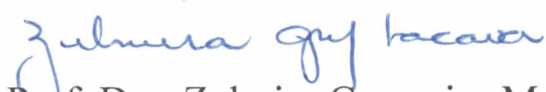

Prof. Dra .Zulmira Guerreiro Marques Lacava Titular Interno vinculado ao programa UnB 
Dedico esta dissertação aos pacientes e familiares vítimas do câncer. Aos pesquisadores e profissionais da saúde que passam ou passaram parte de suas vidas buscando o melhor tratamento para esses pacientes.

"É preciso amar as pessoas como se não houvesse amanhã. Porque se você parar pra pensar, na verdade não há." (Pais e filhos - Legião Urbana) 
À minha orientadora, Professora Dra Maria de Fátima Menezes Almeida Santos, pela orientação, exemplo de profissionalismo, que contribuíram não só na minha vida acadêmica, mas também na minha formação como pessoa. Obrigado por investir e confiar em mim.

Ao meu Coorientador, Professor Dr. Ricardo Bentes de Azevedo, pelo acolhimento, pela oportunidade de trabalhar em seu laboratório e por acreditar em meu potencial.

Ao Professor Dr. João Paulo Figueiró Longo, pelo tempo e dedicação ajudando nas analises estatísticas.

À Bióloga Karen R. Py-Daniel, que me acolheu no Laboratório de Nanobiotecnologia, com você aprendi muito. Você foi uma mãe acadêmica.

À Ana Lygia D.S. Câmara, pela ajuda na parte experimental desse estudo, pelo companheirismo dentro e fora do Laboratório de Nanobiotecnologia. Trabalhamos, mas também rimos muito. Uma amiga mais que especial. Amigos por varias afinidades, principalmente gostos musicais, meu "nanoamor".

À Laise R. D. Andrade, pela amizade, logo de cara gostei de estar perto de você, compartilhar segredos. $E$ sempre me animou nos momentos difíceis.

Aos professores membros da banca examinadora, por terem aceitado o convite para a avaliação do presente trabalho.

À todos os professores do Programa de Pós-Graduação em Nanociência e Nanobiotecnologia da Universidade de Brasília, que tive a oportunidade de conhecer, em especial àqueles com quem realizei disciplinas: Dra. Jaqueline R. da Silva, Dr. 
Sacha B. Chaves, Dr. Luis A. Muehlmann, Dra. Graziela Joanitti, Dr. Marcelo H. Sousa, Dr. Sebastião W. da Silva e Dr. José A. H. Coaquira.

À todos os amigos e colegas do Laboratório de Nanobiotecnologia do Departamento de Genética e Morfologia da UnB,em especial à Raphael S. Bonadio, Henrique Loback, Rayane Ganassin, Ana Paula Bastos, Barbara M. Rodrigues, Débora S.Santos, Paolin R. C.Vélez, Nayara John, Paula Q. Alvim, Maria Luiza Fascineli, Mayara Simonelly, Edejan H. D.Paula, Mario Junior, Cesar Romero, Daniela Moraes, Antônio Djalma Santos, Frederico H. Horst, Sarah R. Py-Daniel, Ludmilla David, Luiza Lima, Marina C. Sampaio, Jaqueline R. da Silva, Palloma, Janaína G.Penteado, Sebastian L. Biswaro, Willian M. Junior, José de Souza Filho ${ }^{\dagger}$ pela colaboração, incentivo, discussões acadêmicas, amizade e principalmente pelas boas risadas.

À Dona Zélia por todo auxílio no Laboratório de Nanobiotecnologia.

Aos meus amigos, Fisioterapeutas, Dr. Hélio Gustavo Santos, Dra. Luíza C. Machado e Dra. Natália Grancieri que sempre apoiam e incentivam as minhas decisões profissionais. E aos amigos Carla Santana, Mayara M. G. da Silva, Douglas de Souza, Ruanna Moura, Flávia Lima, Netto Barcelos, Marcello V.C.L. Mororó que fizeram de Brasília um lugar mais agradável.

Aos meus familiares (Tios, Tias, Primos, Primas, Avó, Avô) que estão sempre presentes em minha vida. A minha irmã, Mayara Candeia Gianizeli, e meu cunhado Rewerton $H$. Lovatte pela amizade e carinho sem limite. A você mãe, Rosa Candeia Gianizeli, pelo amor incondicional e companheirismo em todos os momentos da minha vida, mesmo quando pedia para eu largar tudo e voltar para casa. Ao meu Pai: Valchimar Vianna Gianizeli, mesmo que eu não Ihe veja, posso sentir sua presença, sei que você esteve comigo, me guiando e compartilho esta realização, pois mais que minha, ela é sua.

À Universidade de Brasília pelo fornecimento da estrutura para realização deste estudo. 
À CAPES e ao INCT de Nanobiotecnologia pelo apoio financeiro.

À Deus, pela vida e por ter posto estas pessoas maravilhosas em meu caminho.

MUITO OBRIGADO!!! 
A prevenção e o diagnóstico precoce, associado ao tratamento eficaz de qualquer tipo de câncer, são fundamentais para que os índices de incidência e mortalidade por câncer possam ser reduzidos. A busca pelo tratamento eficaztem inspirado o desenvolvimento de novas plataformas terapêuticas, como a utilizaçãode fármacos associados ànanossistemas. Nesse contexto, realizou-seo presente estudoque teve como objetivo avaliar,in vitro,a eficácia deum material nanoestruturado, $\mathrm{Fe}_{2} \mathrm{O}_{3} / \mathrm{AO} / \mathrm{P}-\mathrm{F} 127-\mathrm{AlClFt}$, na terapia fotodinâmica, TFD. Para tal, utilizou-se células daslinhagensNIH-3T3, MCF-7, A431 eHeLa. Os resultados mostram que o fotossensibilizante AICIFt, livre ou adsorvido a $\mathrm{Fe}_{2} \mathrm{O}_{3} / \mathrm{AO} / \mathrm{P}-\mathrm{F} 127$,quando irradiado, induz a produção de oxigênio singleto eao ser incorporado pelas células sealoja no seu citoplasma. A análise dos resultados mostra também que a TFD mediada por esse nanomaterial, em diferentes concentrações de AICIFt,écitotóxica, induzindo as células das quatro linhagens à necrose, embora induza despolarização somente das membranas mitocondriaisdas células da linhagem NIH-3T3. Além disso, a TFD mediada por $\mathrm{Fe}_{2} \mathrm{O}_{3} / \mathrm{AO} / \mathrm{P}-\mathrm{F} 127$, com AlClFt na concentração de $0,04 \mu \mathrm{g} / \mathrm{mL}$ induziu fragmentação no DNA de células das linhagens NIH-3T3 e MCF-7, e com AlCIFt na concentração de $0,09 \mu \mathrm{g} / \mathrm{mL}$ induziu também fragmentação no DNA de células das linhagens A431.Após duas sessões de TFD mediada pela $\mathrm{Fe}_{2} \mathrm{O}_{3} / \mathrm{AO} / \mathrm{P}-\mathrm{F} 127-\mathrm{AICIFt}$, com AICIFt na concentração de $0,09 \mu \mathrm{g} / \mathrm{mL}$, as células das quatro linhagensforam praticamente eliminadas em menos de cinco dias, o que evidencia opotencial da $\mathrm{Fe}_{2} \mathrm{O}_{3} / \mathrm{AO} / \mathrm{P}-\mathrm{F} 127-\mathrm{AlClFt}$ a ser utilizado na TFD.

Palavras-chave: nanobiotecnologia, terapia fotodinâmica; Alumínio-CloroFtalocianina, nanopartículas magnéticas. 
Cancer prevention, early diagnosis, andtreatment are essential to reduce the cancer incidence and mortality rates. The ideal cancer treatment involves effective therapies with minimal side effects. Aiming to better cancer treatment, therapeutic solutions, such as the use of drugsdelivery, is being developing. Here we evaluate the efficacy of $\mathrm{Fe}_{2} \mathrm{O}_{3} / \mathrm{AO} / \mathrm{P}-\mathrm{F} 127-\mathrm{AlClFt}$, a nanostructure, in the photodynamic therapy, PDT, using NIH-3T3, MCF-7, A431 andHeLacells lines. According to our results, photosensitizing AICIFt adsorbed to the $\mathrm{Fe}_{2} \mathrm{O}_{3} / \mathrm{AO} / \mathrm{P}-\mathrm{F} 127$ induces the production of singlet oxygen when irradiated. When the nanostructures enter the cells, theyremain in their cytoplasm.In addition, PDT mediated by $\mathrm{Fe}_{2} \mathrm{O}_{3} / \mathrm{AO} / \mathrm{P}-\mathrm{F} 127-\mathrm{AlClFt}$ at different drug concentrations is cytotoxic, and, although induces depolarization only of mitochondrial membranes of $\mathrm{NIH}-3 \mathrm{~T} 3$ cells, it induces necrosis in the cells ofthe four cell lines. The PDTmediated by $\mathrm{Fe}_{2} \mathrm{O}_{3} / \mathrm{AO} / \mathrm{P}-\mathrm{F} 127$ with $0.04 \mu \mathrm{g} / \mathrm{mlof} \mathrm{AICIFt}$ induced DNA fragmentation of NIH-3T3 and MCF-7cells and with $0.09 \mu \mathrm{g} / \mathrm{ml}$ of AICIFt also induced DNA fragmentation in A431 cells. After two sessions of PDT mediated by $\mathrm{Fe}_{2} \mathrm{O}_{3} / \mathrm{AO} / \mathrm{P}-\mathrm{F} 127-\mathrm{AlClFt}$ with $0.09 \mu \mathrm{g} / \mathrm{mL}$ AlCIFt, cells of all the four lines were eliminated in less than five days, which shows the potential of $\mathrm{Fe}_{2} \mathrm{O}_{3} / \mathrm{AO} / \mathrm{P}-\mathrm{F} 127-\mathrm{AlClFt}$ to be used in the photodynamic therapy.

Keywords: nanobiotecnology; photodynamic therapy; magnetic nanoparticles aluminium phthalocyanine chloride; 
Figura 1. Diagrama de Jablonsky simplificado. Mecanismo geral de geração de espécies reativas de oxigênio mediadas ela luz. Fonte: Oliveira e colaboradores, 2015.

Figura 2. Desenho experimental para determinar a dose de energia $\left(\mathrm{J} / \mathrm{cm}^{2}\right)$ que as células suportariam sem comprometer a sua viabilidade na ausência da $\mathrm{Fe}_{2} \mathrm{O}_{3} / \mathrm{AO} / \mathrm{P}-\mathrm{F} 127-\mathrm{AlClFt}$

Figura 3. Equipamento de análise da dinâmica de proliferação celular em tempo real (Real Time Cell Analysis - RTCA), acessado de http://www.aceabio.com, em maio de 2015

Figura 4. Viabilidade, determinada por meio do ensaio de metabolização de brometo de 3 (4,5 dimetiltiazol-2il)-2,5difenil-tetrazólio), das diferentes linhagens celulares após irradiação com diferentes densidades de energia na ausência da $\mathrm{Fe}_{2} \mathrm{O}_{3} / \mathrm{AO} / \mathrm{P}-\mathrm{F} 127-\mathrm{AlCIFt}$.

Figura 5 Espectros de absorbância da AICIFt, adsorvida ou não a um fluido magnético constituído de nanopartículas de magnetita revestidas com uma monocamada de ácido oleico associado ao polímero Pluronic F-127 ( $\left.\mathrm{Fe}_{2} \mathrm{O}_{3} / \mathrm{AO} / \mathrm{P}-\mathrm{F} 127-\mathrm{AlCIFt}\right)$, mensurada pela degradação do Benzofurano após irradiação por fonte diodo emissor de luz $(\lambda=660 \mathrm{~nm})$ com diferentes densidades de energia $\left(\mathrm{J} / \mathrm{cm}^{2}\right)$, na presença de oxigênio 
Figura 6 Citotoxicidade induzida pela terapia fotodinâmica mediada pela $\mathrm{AlClFt}$ adsorvida $\mathrm{aFe}_{2} \mathrm{O}_{3} / \mathrm{AO} / \mathrm{P}-\mathrm{F} 127$ com diferentes concentrações de AlCIFt adsorvida, em células da linhagem $\mathrm{NIH}-3$ T3 irradiadas com densidade de energia de $23,70 \mathrm{~J} / \mathrm{cm}^{2}$, determinada por meio do ensaio de metabolização de brometo de 3 (4,5 dimetiltiazol-2il)-2,5-difenil-tetrazólio)............

Figura 7 Citotoxicidade induzida pela terapia fotodinâmica mediada pela $\mathrm{AlClFt}$ adsorvida $\mathrm{aFe}_{2} \mathrm{O}_{3} / \mathrm{AO} / \mathrm{P}-\mathrm{F} 127$ com diferentes concentrações de AICIFt adsorvida, em células da linhagem MCF-7 irradiadas com densidade de energia de $23,70 \mathrm{~J} / \mathrm{cm}^{2}$, determinada por meio do ensaio de metabolização de brometo de 3 (4,5 dimetiltiazol-2il)-2,5-difenil-tetrazólio)............

Figura 8 Citotoxicidade induzida pela terapia fotodinâmica mediada pela $\mathrm{AlClFt}$ adsorvida $\mathrm{aFe}_{2} \mathrm{O}_{3} / \mathrm{AO} / \mathrm{P}-\mathrm{F} 127$ com diferentes concentrações de AlCIFt adsorvida, em células da linhagem A431 irradiadas com densidade de energia de $23,70 \mathrm{~J} / \mathrm{cm}^{2}$, determinada por meio do ensaio de metabolização de brometo de 3 (4,5 dimetiltiazol-2il)-2,5-difenil-tetrazólio)..........

Figura 9 Citotoxicidade induzida pela terapia fotodinâmica mediada pela $\mathrm{AlClFt}$ adsorvida $\mathrm{aFe}_{2} \mathrm{O}_{3} / \mathrm{AO} / \mathrm{P}-\mathrm{F} 127$ com diferentes concentrações de AICIFt adsorvida, em células da linhagem HeLa irradiadas sob densidade de energia de $23,70 \mathrm{~J} / \mathrm{cm}^{2}$, determinada por meio do ensaio de metabolização de brometo de 3 (4,5 dimetiltiazol-2il)-2,5-difenil-tetrazólio)...........

Figura 10 Concentração de $\mathrm{AlClFt}$ adsorvida $\mathrm{aFe} \mathrm{O}_{3} / \mathrm{AO} / \mathrm{P}-\mathrm{F} 127$ capaz de eliminar $50 \%$ das células de uma população das linhagens celulares NIH-3T3, A431, HeLa e MCF-7 submetidas à terapia fotodinâmica e irradiadas com densidade de energia igual a 
$23,70 \mathrm{~J} / \mathrm{cm}^{2}$

Figura 11 Taxa de incorporação de AICIFt livre ou adsorvida a $\mathrm{Fe}_{2} \mathrm{O}_{3} / \mathrm{AO} / \mathrm{P}-\mathrm{F} 127$ nas células das linhagens NIH-3T3, MCF-7, A431 e HeLa, por meio do método de cromatografia líquida de alta eficiência. $\left({ }^{*}\right)$ denota diferença significativa entre as linhagens células. Dados estão representados como média \pm EPM para duplicata.

Figura 12 Fotomicrografia confocal de células da linhagem MCF-7 (I) e A431 (II), 15 minutos após serem submetidas àAICIFt livre (I) $\mathrm{Fe}_{2} \mathrm{O}_{3} / \mathrm{AO} / \mathrm{P}-\mathrm{F} 127-\mathrm{AICIFt}$ (II) na concentração de 0,09 $\mu \mathrm{g} / \mathrm{mL}$. ( $A$ e $D$ ) coloração azul mostra o núcleo das células corado com DAPI; (B e E) coloração vermelha é o resultado da florescência da AICIFt livre e adsorvida a $\mathrm{Y}-\mathrm{Fe}_{2} \mathrm{O}_{3} / \mathrm{AO} / \mathrm{P}$ F127, respectivamente, no citoplasma (setas); (C) sobreposição das imagens $A-B ;(F)$ sobreposição das imagens D-E.

Figura 13 Histogramas representativos obtidos em citômetro de fluxo de células da linhagem A431 coradas com Anexina-V-FITC e lodeto de propídio. (A) Células controle (B) células tratadas com $\mathrm{Fe}_{2} \mathrm{O}_{3} / \mathrm{AO} / \mathrm{P}-\mathrm{F} 127-\mathrm{AlClFt}$, cuja concentração de AICIFt é $0,04 \mu \mathrm{g} / \mathrm{mL}$ e irradiadas com Luz LED sob densidade de energia de $23,70 \mathrm{~J} / \mathrm{cm}^{2}$; (C) células tratadas com $\mathrm{Fe}_{2} \mathrm{O}_{3} / \mathrm{AO} / \mathrm{P}$ F127-AICIFt, cuja concentração de AICIFt é $0,09 \mu \mathrm{g} / \mathrm{mL}$, e irradiadas com Luz LED com densidade de energia de $23,70 \mathrm{~J} / \mathrm{cm}^{2}$ 
Figura 14 Ensaio de Anexina-V/FITC. Frequência de morte celular por necrose (cinza) e apoptose (preto) em células da NIH-3T3, MCF-7, A431 e HeLa submetidas à terapia fotodinâmica, mediada por $\mathrm{Fe}_{2} \mathrm{O}_{3} / \mathrm{AO} / \mathrm{P}-\mathrm{F} 127-\mathrm{AlClFt}$ com concentrações de AlCIFt iguais a $0,04 \mu \mathrm{g} / \mathrm{mL}$ e $0,09 \mu \mathrm{g} / \mathrm{mL}$ e irradiadas com densidade de energia igual a $23,70 \mathrm{~J} / \mathrm{cm}^{2}$. Dados estão representados como média \pm EPM para duplicata.

Figura 15 Histogramas representativos do potencial elétrico de membranas mitocondriais de células da linhagem MCF-7 coradas com Rodamina-123. (A) células controle (B) células submetidas à terapia fotodinâmica mediada $\mathrm{Fe}_{2} \mathrm{O}_{3} / \mathrm{AO} / \mathrm{P}$ F127-AICIFt, cuja concentração de AICIFt é $0,04 \mu \mathrm{g} / \mathrm{mL}$ e irradiadas com Luz LED com densidades de energia de $23,70 \mathrm{~J} / \mathrm{cm}^{2} ;$ (C) células tratadas com $\mathrm{Fe}_{2} \mathrm{O}_{3} / \mathrm{AO} / \mathrm{P}-\mathrm{F} 127$ AICIFt, cuja concentração de AICIFt é $0,09 \mu \mathrm{g} / \mathrm{mL}$ e irradiadas com Luz LED com densidades de energia de $23,70 \mathrm{~J} / \mathrm{cm}^{2}$

Figura 16 Frequência de células NIH-3T3, MCF-7, A431 e HeLa com despolarização de membranas mitocondriais após serem submetidas à terapia fotodinâmica mediada pela $\mathrm{AlCIFt}$ adsorvida $\mathrm{aFe}_{2} \mathrm{O}_{3} / \mathrm{AO} / \mathrm{P}-\mathrm{F} 127$, nas concentrações de 0,04 $\mu \mathrm{g} / \mathrm{mL}$ e $0,09 \mu \mathrm{g} / \mathrm{mL}$ e irradiadas com densidade de energia igual a $23,70 \mathrm{~J} / \mathrm{cm}^{2}$. Dados estão representados como média \pm EPM para duplicata. Símbolos $\left({ }^{*}\right)$ denotam diferenças significativas dentro da mesma linhagem em relação ao controle. 
Figura 17 Frequência de fragmentação do DNA em células NIH-3T3, MCF-7, A431 e HeLa submetidas à terapia fotodinâmica, mediada por $\mathrm{AlClFt}$ adsorvida $\mathrm{aFe}_{2} \mathrm{O}_{3} / \mathrm{AO} / \mathrm{P}-\mathrm{F} 127$, nas concentrações de $0,04 \mu \mathrm{g} / \mathrm{mL}$ e $0,09 \mu \mathrm{g} / \mathrm{mL}$ e irradiadas com densidade de energia igual a $23,70 \mathrm{~J} / \mathrm{cm}^{2}$. Dados estão representados como média \pm EPM para duplicata. Letras distintas denotam diferenças significativas dentro da mesma linhagem

Figura 18 Dinâmica da proliferação celular da linhagem NIH-3T3, antes e após duas sessões de terapia fotodinâmica, mediada por AlCIFtadsorvida $\quad \mathrm{aFe}_{2} \mathrm{O}_{3} / \mathrm{AO} / \mathrm{P}-\mathrm{F} 127 \mathrm{com}$ diferentes concentrações de AICIFt e irradiadas com luz LED com densidade de energia igual a $23,70 \mathrm{~J} / \mathrm{cm}^{2}$. (A) Índice celular antes (negativo), após 48 horas da primeira sessão da terapia fotodinâmica (seta preta), 48 horas após a segunda sessão da terapia fotodinâmica (seta vermelha); (B) Área sob a curva do padrão de proliferação das células

Figura 19 Dinâmica da proliferação celular da linhagem MCF-7, antes e após duas sessões de terapia fotodinâmica, mediada por AlCIFt adsorvida $\mathrm{aFe}_{2} \mathrm{O}_{3} / \mathrm{AO} / \mathrm{P}-\mathrm{F} 127 \mathrm{com}$ diferentes concentrações de AICIFt e irradiadas com luz LED com densidade de energia igual a $23,70 \mathrm{~J} / \mathrm{cm}^{2}$. (A) Índice celular antes (negativo), após 48 horas da primeira sessão da terapia fotodinâmica (seta preta), 48 horas após a segunda sessão da terapia fotodinâmica (seta vermelha); (B) Área sob a curva do padrão de proliferação das células 
Figura 20 Dinâmica da proliferação celular da linhagem A431, antes e após duas sessões de terapia fotodinâmica, mediada por AlCIFt adsorvida $\mathrm{aFe}_{2} \mathrm{O}_{3} / \mathrm{AO} / \mathrm{P}-\mathrm{F} 127 \mathrm{com}$ diferentes concentrações de AICIFt e irradiadas com luz LED sob com densidade de energia igual a $23,70 \mathrm{~J} / \mathrm{cm}^{2}$. (A) Índice celular antes (negativo), após 48 horas da primeira sessão da terapia fotodinâmica (seta preta), 48 horas após a segunda sessão da terapia fotodinâmica (seta vermelha); (B) Área sob a curva do padrão de proliferação das células

Figura 21 Dinâmica da proliferação celular da linhagem HeLa, antes e após duas sessões de terapia fotodinâmica, mediada por AICIFt adsorvida $\mathrm{aFe}_{2} \mathrm{O}_{3} / \mathrm{AO} / \mathrm{P}-\mathrm{F} 127 \mathrm{com}$ diferentes concentrações de AICIFt e irradiadas com luz LED com densidade de energia igual a $23,70 \mathrm{~J} / \mathrm{cm}^{2}$. (A) Índice celular antes (negativo), após 48 horas da primeira sessão da terapia fotodinâmica (seta preta), 48 horas após a segunda sessão da terapia fotodinâmica (seta vermelha); (B) Área sob a curva do padrão de proliferação das células 
Tabela 1 Linhagens celulares utilizadas no presente estudo.

Tabela 2 Grupos experimentais utilizados para determinar a taxa de incorporação e o padrão de distribuição intracelular do fotossensibilizante Alumínio-Cloro-Ftalocianina em células,in vitro,determinados, respectivamente, por meio de um sistema de cromatografia líquida de alta eficiência epormicroscopia confocal.

Tabela 3 Grupos experimentais utilizados para determinar o perfil de morte celular induzido pela terapia fotodinâmica, mediada pelo nanomaterialFe $\mathrm{O}_{3} / \mathrm{AO} / \mathrm{P}-\mathrm{F} 127-\mathrm{AICIFt}$ irradiadocom densidade de energia igual $23,70 \mathrm{~J} / \mathrm{cm}^{2}$, por meio do ensaio de AnexinaV/FITC

Tabela 4 Grupos experimentais utilizados para avaliar o potencial de membranas mitocondriais de células submetidas à terapia fotodinâmica mediada pelo nanomaterial $\mathrm{Fe}_{2} \mathrm{O}_{3} / \mathrm{AO} / \mathrm{P}-\mathrm{F} 127-$ AICIFtirradiadocom densidade de energia igual $23,70 \mathrm{~J} / \mathrm{cm}^{2}$, por meio do ensaio de Rodamina

Tabela 5 Grupos experimentais utilizados para analisar a fragmentação do DNA em células submetidas à terapia fotodinâmica mediada pelo nanomaterial $\mathrm{Fe}_{2} \mathrm{O}_{3} / \mathrm{AO} / \mathrm{P}-\mathrm{F} 127-\mathrm{AICIFt}$ irradiado com densidade de energia igual $23,70 \mathrm{~J} / \mathrm{cm}^{2}$, por meio de citometria de fluxo.

Tabela 6 Grupos experimentais utilizados para analisar a dinâmica de proliferação das células submetidas à terapia fotodinâmica mediada pelo nanomaterialFe${ }_{2} \mathrm{O}_{3} / \mathrm{AO} / \mathrm{P}-\mathrm{F} 127-\mathrm{AICIFt}$ irradiado com densidade de energia igual $23,70 \mathrm{~J} / \mathrm{cm}^{2}$. 


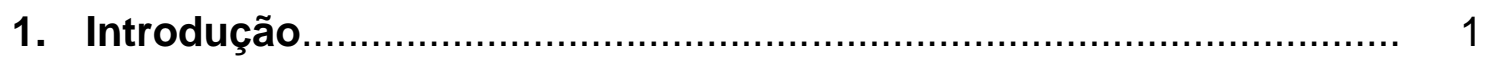

2. Justificativa

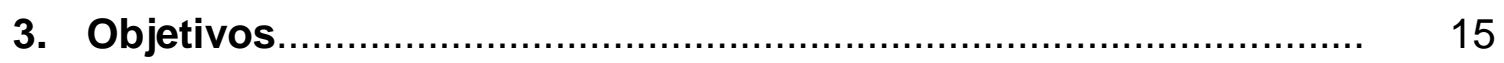

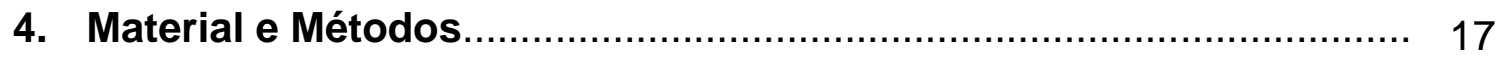

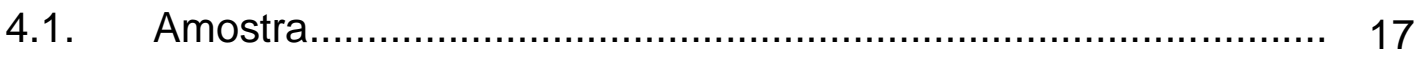

4.2. Fonte de Diodo Emissor de Luz ............................................. 17

4.3. Linhagens celulares........................................................ 18

4.3.1. Manutenção e propagação das células........................... 20

4.4. Determinação da dose de energia a ser aplicada na Terapia Fotodinâmica

4.5. Determinação da capacidade de $\mathrm{Fe}_{2} \mathrm{O}_{3} / \mathrm{AO} / \mathrm{P}-\mathrm{F} 127-\mathrm{AlClFt}$ em gerar oxigênio singleto.

4.6. Determinação da eficácia da Terapia Fotodinâmica mediada peloFe $\mathrm{O}_{3} / \mathrm{AO} / \mathrm{P}-\mathrm{F} 127-\mathrm{AIClFt}$

4.7. Determinação do perfil de incorporação do fotossensibilizante Alumínio-Cloro Ftalocianina por células in vitro.

4.7.1. Determinação da taxa de incorporação do fotossensibilizante Alumínio-Cloro-Ftalocianina por células in vitro, em sistema de cromatografia líquida de alta eficiência.

4.7.2. Análise do padrão de distribuição intracelular do fotossensibilizante Alumínio-Cloro-Ftalocianina por células in vitro, por meio de microscopia confocal. 
4.8. Determinação do perfil de morte celular induzido pela terapia fotodinâmica mediada peloFe2 $\mathrm{O}_{3} / \mathrm{AO} / \mathrm{P}-\mathrm{F} 127-\mathrm{AICIFt}$.

4.9. Análise do potencial elétrico de membranas mitocondriais de células submetidas à terapia fotodinâmica mediada pela $\mathrm{Fe}_{2} \mathrm{O}_{3} / \mathrm{AO} / \mathrm{P}-\mathrm{F} 127-\mathrm{AICIFt}$

4.10. Análise da fragmentação do DNA de células submetidas à terapia fotodinâmica mediada peloFe ${ }_{2} \mathrm{O}_{3} / \mathrm{AO} / \mathrm{P}-\mathrm{F} 127-$ AlCIFt.

4.11. Dinâmica da proliferação celular das células sobreviventes a terapia fotodinâmica mediada peloFe2 $\mathrm{O}_{3} / \mathrm{AO} / \mathrm{P}-\mathrm{F} 127-$ $\mathrm{AlClFt}$

4.12 Análises estatísticas

5. Resultados.

6. Discussão

7. Conclusões.

8. Referências Bibliográficas. 
Câncer é o nome utilizado para designar um grupo de doenças, mais de 100, que podem afetar qualquer parte do corpo (WHO, 2015). Essas doenças em geral constituem organizações morfofuncionais que têm em comum, devido a alterações genéticas, a proliferação desordenada de células (WEINBERG, 2014). Cabe enfatizar que essas organizações morfofuncionais denominadas de câncer, não constituem somente um conjunto de células em proliferação desordenada, mas sim um tecido complexo composto por tipos distintos de células que interagem entre si. Isso porque para as células se tornarem neoplásicas, elas devem, durante as diversas divisões celulares desordenadas, adquirir outras alterações genéticas e/ou epignéticas que Ihes conferem características que são essenciais para o processo carcinogênico, tais como: insensibilidade a fatores antiproliferativos; evasão à morte e aos mecanismos de defesa imune; potencial infinito de replicação; modulação da resposta inflamatória; indução persistente da angiogênese; instabilidade genética e alterações metabólicas adaptativas (HANAHAN \& WEINBERG, 2011). A necessidade da aquisição dessas características explica o fato de a tumorigênese ser um processo complexo que ocorre em várias etapas e envolve alterações em diversas vias metabólicas, que se traduzem no desenvolvimento de novos fenótipos que são continuamente gerados, tanto por alterações na expressão, como na função de determinados genes (GATENBY \& GILLIES, 2007).

Como as células tumorais recrutam outras células para constituir o seu estroma e essas células recrutadas tornam-se participantes ativos na tumorigênese, em vez de espectadores passivos, as células neoplásicas podem, com contribuições do microambiente tumoral, invadir tecidos 
adjacentes e ao atingir vasos sanguíneos podem ser transportadas para outro órgão do corpo, aumentando a probabilidade do desenvolvimento de tumores secundários, em um processo denominado de metástase. Vale lembrar que a metástase tumoral é a principal causa de morte em decorrência de câncer; os tumores primários são responsáveis por apenas 10\% das mortes por câncer, enquanto que os $90 \%$ restantes são devidos aqueles descobertos em locais distantes onde o tumor primário surgiu (Weinberg, 2014). Assim, quando o tumor primário não é eliminado precocemente, o câncer pode se tornar uma doença fatal (GUO et alli, 2014); a chance de pacientes com câncer em estádio avançado se recuperarem da doença ainda permanece pequena (ANG et alli, 2014).

De acordo com a Organização Mundial da Saúde (OMS), em 2012, ocorreram 14 milhões de novos casos de câncer e 8,2 milhões de mortes por câncer em todo o mundo; esse número de óbitos corresponde a $20 \%$ da mortalidade total (WEINBERG, 2014). No Brasil, segundo o Instituto Nacional de Câncer José Alencar Gomes da Silva, INCA, a estimativa para o ano de 2015 aponta para a ocorrência de 576 mil casos novos de câncer. Ainda de acordo com o INCA, em 2030, a carga global de câncer será de mais de 21 milhões de novos casos e 13,2 milhões de mortes por câncer, em consequência não só do crescimento da população mundial, mas principalmente, devido ao envelhecimento desta e à redução da mortalidade por doenças infecciosas em países em desenvolvimento.

Para que os índices de incidência e mortalidade por câncer possam ser reduzidos é fundamental sua prevenção e detecção precoce. Isso porque, apesar da escolha do tratamento anticâncer a ser aplicado depender 
basicamente do estágio clínico da doença, da história do paciente, da localização e do tamanho do tumor, o tratamento anticâncer padrão, que consiste na remoção da massa tumoral, associada ou não à radioterapia e/ou quimioterapia (EBLEN, 2012; ACS, 2013), muitas vezes não consegue erradicar completamente as células tumorais. Um exemplo disso é o fato de a taxa de sobrevivência de pacientes com câncer submetidos à quimioterapia, terapêutica importante para o tratamento oncológico (ZHANG et alli, 2011), não ter aumentado significativamente nas últimas três décadas (GUO et alli, 2014); talvez porque, apesar da diversidade de quimioterápicos utilizados no tratamento de câncer, a maioria deles não diferencia células tumorais de células não tumorais, o que limita a dose máxima admissível, pois leva à toxicidade sistêmica e a efeitos colaterais adversos (MAJl et alli, 2014).

Entretanto, a maior falha da quimioterapia antineoplásica deve-se à resistência das células a drogas. Populações celulares podem sofrer alterações genéticas e por meio da síntese de novas enzimas, metabolizar e/ou neutralizar quimioterápicos (EBLEN, 2012). Também devido a alterações genéticas, populações de células tumorais podem superexpressar a glicoproteína-P (gpP), uma proteína de membrana plasmática que funciona como uma bomba de efluxo, o que leva à diminuição da concentração intracelular do quimioterápico, fenômeno esse denominado de resistência a múltiplas drogas (YHEE et alli, 2015).

Outro método capaz de destruir as células tumorais é a radioterapia, que emprega feixe de radiações ionizantes para erradicar as células tumorais, mas que também promove efeitos colaterais os quais podem ser potencializados pela administração simultânea com quimioterápicos. Entre os efeitos colaterais 
induzidos pela radioterapia e pela quimioterapia pode-se citar a infertilidade, alterações cardíacas, gastrintestinais, endócrinas e renais, além de perda capilar, entre outros (GLENNYA et alli, 2004). Assim, apesar de muitos utilizados, esses métodos, como citado anteriormente, oferecem riscos de dano a tecidos sadios e a erradicação incompleta das células malignas, o que tem inspirado o desenvolvimento de novos métodos para tratar efetivamente 0 câncer. Nesse sentido, o desenvolvimento de propostas de inovação tecnológica com fins de suplantar as dificuldades atuais encontradas no tratamento dos diferentes tipos de câncer constitui um dos objetivos da nanotecnologia.

A nanotecnologia envolve a criação e a manipulação de materiais e dispositivos em escala nonométrica, normalmente, mas não exclusivamente, abaixo de 100 nanômetros. Nessas dimensões manométricas as nanoestruturas apresentam propriedades físicas, químicas e biológicas, diferentes das existentes dos materiais em escalas micro ou macroscópicas, (ISO/TC 229 Nanotechnologies, acessado em março de 2015) que Ihes permitem ser utilizados nas mais diversas áreas, tais como: eletrônica, engenharia de alimentos, biomedicina entre outras (ISO/TC 229 Nanotechnologies, acessado em março de 2015).

$\mathrm{Na}$ área biomédica a aplicação da nanotecnologia vem se mostrando promissora no desenvolvimento de sistemas de carreamento e liberação de drogas para melhorar a eficácia terapêutica de velhos e novos fármacos. Após ajuste das suas características, esses nanossistemas podem passar mais facilmente por barreiras celulares e serem capazes de interagir com células, influenciando processos fisiológicos (SUGANYA et alli, 2015). Além disso, 
podem ser criados nanossistemas capazes de detectar células neoplásicas no corpo e como, em geral, esses nanossistemas são 100 a 10 mil vezes menores do que as células neoplásicas, eles podem facilmente passar por barreiras celulares e se acumular nas células tumorais. Além do tamanho favorável, as nanopartículas apresentam diversas outras vantagens que permitem que sejam utilizadas em um organismo vivo: podem ser biodegradáveis; ter suas superfícies modificadas para criar grupos funcionais contendo diversas propriedades bioquímicas; serem projetadas de modo a não sofrer efeitos enzimáticos, dando total proteção aos fármacos encapsulados e podem também ser modificadas para não ativar o sistema imunitário. Mas como um dos principais problemas associados aos tratamentos convencionais do câncer é a incapacidade dos fármacos antineoplásicos chegarem ao tecido tumoral sem causar toxicidade a tecidos não tumorais, a veiculação de quimioterápicos em nanoestruturas é vantajosa para o tratamento do câncer, pois, além de tornar os quimioterápicos mais estáveis e mais solúveis (GUO et alli, 2014), aumentar a sua meia vida, e de os tornar mais eficazes para superar a resistência a drogas apresentada por células tumorais, permite 0 direcionamento do princípio ativo para seu alvo específico, contribuindo assim para a superação das limitações do tratamento padrão do câncer.

Dentre os nanossistemas que podem ser utilizados para carreamento de fármacos destacam-se os lipossomas, vesículas esféricas produzidas com fosfolipídios naturais e colesterol, onde fármacos hidrossolúveis ficam encapsulados no interior da cavidade lipossomal, enquanto que os fármacos lipossolúveis são incorporados na bicamada lipídica. Essa bicamada pode se fundir com outras bicamadas lipídicas, como as das células, liberando o 
conteúdo lipossomal (ROSSI-BERGMANN, 2008). Outro tipo de nanossistema utilizado para carreamento de drogas são aqueles constituídos de nanopartículas poliméricas, às quais o fármaco é agregado, encapsulado ou adsorvido. Outra possibilidade de vetorização de um fármaco é a sua associação a nanopartículas magnéticas que, por meio da aplicação externa de um campo magnético sobre o tumor, permite que elas sejam levadas até a massa tumoral, liberando aí o fármaco (BOLFARINI et alli, 2012 ).

Nanopartículas magnéticas podem ser constituídas de diferentes ferritas, como as de cobalto, manganês, zinco e ferro, sendo as de óxidos de ferro as mais comuns, as quais apresentam comportamento superparamagnético e respondem a um campo magnético. Por isso é que elas podem ser guiadas até ao tecido tumoral por campos magnéticos externos e ali acumularem-se. Desse modo, além de poderem ser utilizadas como carreadoras de drogas, como citado anteriormente, elas podem também ser utilizadas como contrataste em ressonância magnética nuclear (BAI LY et alli, 2015) para produzir imagens de estruturas internas do organismo. Vale lembrar que as nanopartículas magnéticas podem também ser aplicadas diretamente no alvo desejado.

Qualquer que seja a forma como as nanopartículas magnéticas tenham chegado ao sitio alvo, no contexto do câncer, quando acumuladas no tumor, carreando ou não fármacos, as nanopartículas magnéticas ao serem submetidas a um campo magnético externo de frequência alternada promovem aumento da temperatura no local que pode eliminar células neoplásicas, em um processo de hipertermia, ou mais precisamente de magnetohipertermia. $\mathrm{O}$ principio da magnetohipertermia está relacionado à dissipação de energia por um material ferromagnético quando Ihe é aplicado um campo magnético 
externo de frequência alternada. O interessante é que se as nanopartículas magnéticas estiverem associadas às células tumorais, o calor dissipado pode matar essas células e eliminar o tumor sem prejudicar as demais células do organismo. Isso ocorre porque a toxicidade dos tecidos biológicos somente ocorre quando os limites de tolerância à hipertermia são excedidos, ou seja, quando a temperatura intracelular for maior do que $44 \stackrel{\circ}{ } \mathrm{C}$. Entretanto, a morte de células tumorais pode ocorrer a temperaturas entre 41 e $44^{\circ} \mathrm{C}$, temperatura essa promovida pela magnetohipertermia. Essa maior sensibilidade das células tumorais à hipertermia deve-se, muito provavelmente, porque tumores sólidos têm a arquitetura do sistema vascular caótica, o que resulta, devido à perfusão sanguínea insuficiente, em regiões de hipóxia e baixo pH, condições essas que tornam temperaturas entre $40-44{ }^{\circ} \mathrm{C}$ citotóxicas (ZEE, 2002). A citotoxicidade induzida pela magnetohipertermia envolve a desnaturação de proteínas, inclusive as que constituem os complexos enzimáticos envolvidos na síntese e no reparo de DNA (ZEE, 2002), além de modificações no citoesqueleto, tumefação citoplasmática e rompimento das membranas celulares.

Devido ao tamanho nanométrico, as nanopartículas magnéticas apresentam alta relação de área de superfície/volume, o que as torna muito reativas, sendo necessário estabilizá-las, pois quando não são estabilizadas elas tendem a se aglomerar, formando uma estrutura com dimensões que excedem os limites nanométricos. A estabilização das nanopartículas magnéticas pode ser obtida revestindo-as com moléculas biodegradáveis tal como o ácido oleico, e assim poderem ser aplicadas em organismos vivos.

Dentre os fármacos que podem ser acoplados a nanopartículas magnéticas estão os fotossensibilizantes, moléculas que após serem 
fotoativadas são reconhecidamente capazes de induzir as células neoplásicas à morte, em uma modalidade terapêutica denominada de terapia fotodinâmica, TFD, modalidade terapêutica inovadora, minimamente invasiva (WOJTONISZAK et alli, 2013; MAJUMDAR et alli, 2014), aprovada para utilização no tratamento de determinados tipos de câncer, bem como em outras doenças não oncológicas (HUANG et alli, 2011).

A TFD, além de um fotossensibilizante, envolve luz, em determinado comprimento de onda, e oxigênio molecular. A combinação desses componentes leva à transferência de energia da molécula fotossensível para o oxigênio molecular, gerando espécies reativas capazes de destruir células tumorais.

A cadeia de reações que ocorrem na TFD inicia quando o fármaco fotossensibilizante, FS, administrado tópica ou sistemicamente, é irradiado. Nessa situação, como ilustrado na Figura 1, o FS absorve fótons da luz e as suas moléculas saem do estado fundamental (SO), de mais baixa energia, e passam para um estado singleto excitado (Sn). O FS no estado Sn pode retornar ao estado fundamental dispersando a energia adquirida na forma de luz fluorescente, ou passar por um processo denominado de cruzamento intersistema em que as moléculas excitadas são conduzidas a um estado eletronicamente de maior energia, porém mais estável que o estado singleto, ou seja, para um estado tripleto excitado (S1); o FS no estado S1 é mais estável, tende a ter mais tempo de vida disponível quando comparado com o FS no estado Sn (MAJUMDAR et alli, 2014). A energia do FS nesse estado S1, por meio de um mecanismo denominado de reação do Tipo I, pode ser transferida para um substrato celular formando íons radicais. Estes íons 
radicais podem interagir com o oxigênio do meio, gerando espécies reativas de

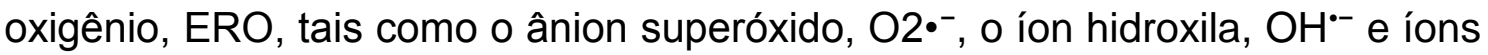
peróxidos, $\mathrm{H}_{2} \mathrm{O}_{2}$. Essas ERO por sua vez podem interagir com biomoléculas.

Em outro tipo de mecanismo, reação do Tipo II, o fotossensibilizante em seu estado tripleto (S1) pode interagir com o oxigênio molecular $\left(\mathrm{O}_{2}\right)$, que normalmente também se encontra no estado de excitação tripleto, e formar oxigênio singleto $\left({ }^{1} \mathrm{O}_{2}\right)$. Esta forma reativa do oxigênio $\left({ }^{1} \mathrm{O}_{2}\right)$ é centenas de vezes mais reativa que a forma molecular, $\mathrm{O} \mathrm{O}_{2}$, sendo referida como a grande responsável pelos efeitos oxidantes da TFD, pois, por meio de ligações covalentes, ela oxida as biomoléculas próximas ao sítio de acúmulo do FS (MAJUMDAR et alli, 2014). Ao oxidar biomoléculas, as espécies reativas de oxigênio podem ocasionar a morte celular, por meio de apoptose, necrose e/ou autofagia.

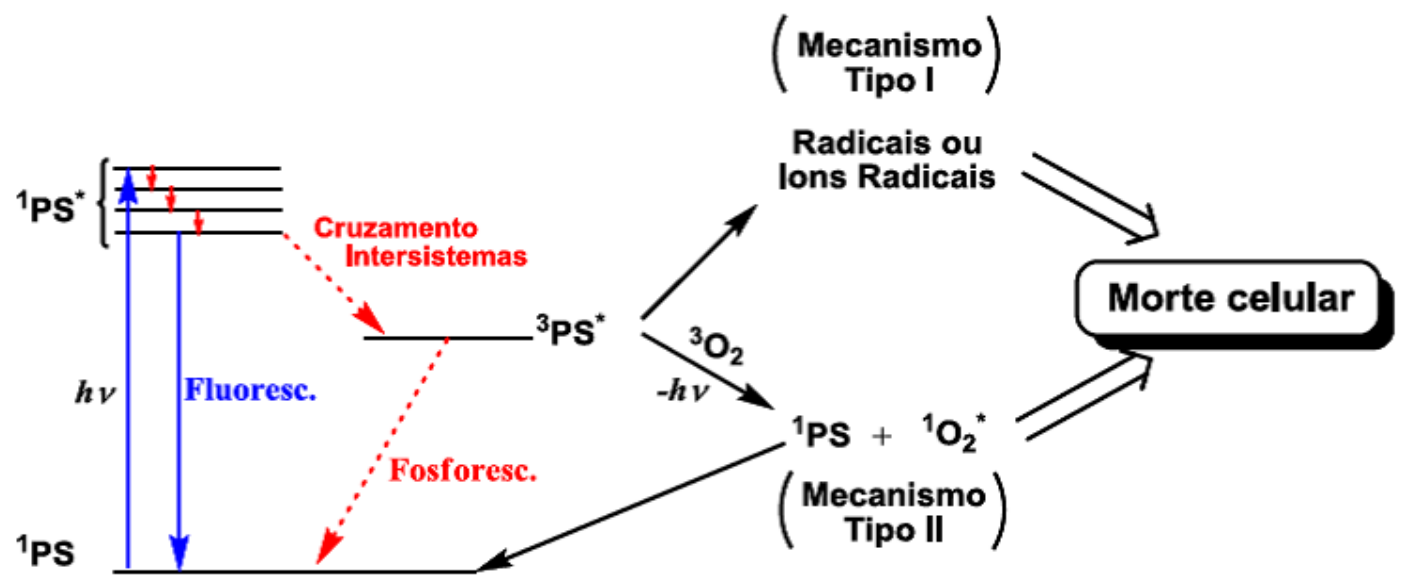

Figura 1. Diagrama de Jablonsky simplificado. Mecanismo geral de geração de espécies reativas de oxigênio mediadas ela luz. Fonte: Oliveira e colaboradores, 2015.

Esses dois tipos de reações podem ocorrer simultaneamente, e a frequência de cada processo depende da concentração intracelular do FS. Como as células tumorais normalmente apresentam maior concentração de 
receptores de lipoproteínas de baixa densidade, LDL, do que as células não tumorais (FAVERO \& BYDLOWSKI, 2008), proteínas essas com as quais os FS apresentam alta afinidade (JORI \& REDDI, 1993), acaba ocorrendo, preferencialmente, maior acúmulo do fotossensibilizante no tecido tumoral. Desse modo a concentração de ${ }^{1} \mathrm{O}_{2}$ gerado após a irradiação do FS danifica biomoléculas em quantidade suficiente para promover morte celular no tecido tumoral (AIBANI et alli, 2014).

Além da concentração intracelular do FS, o sucesso da TFD depende também das características do fotossensibilizante, pois é a partir deles que ocorre a transição da energia fotoelétrica para a energia química. Um FS ideal deve apresentar diversas características tais quais: alta pureza química, alto coeficiente de absorção de luz, baixa tendência à agregação no meio aquoso, alto rendimento de produção de ${ }^{1} \mathrm{O}_{2}$, mínima toxicidade no escuro, ou seja, citotoxicidade apenas quando irradiado, eliminação rápida do organismo, além disso, não deve apresentar potencial mutagênico ou carcinogênico.

Os primeiros FS a serem utilizados na TFD, ou seja, a primeira geração de FS foram os derivados de hematoporfirinas, sendo o primeiro deles 0 Photofrin $\AA^{\circledR}$. Embora esses FS represente um progresso na pesquisa de terapias oncológicas, eles apresentam algumas limitações, como baixa absorção no comprimento de onda de 600-800nm e, portanto, necessidade de doses altas de luz, o que gera danos não específicos (KOLAROVA et alli, 2007). Além disso, esses FS são excretados muito lentamente pelo organismo, o que leva a sua retenção prolongada na pele, exigindo assim que o paciente permaneça ao abrigo da luz por vários dias para evitar o surgimento de lesões cutâneas (KOLAROVA et alli, 2007). Em razão disso, elaboraram-se pesquisas 
de modo a desenvolver FS mais eficientes, o que originou a chamada segunda geração de FS. De maneira geral, essa nova geração de FS possui propriedades fotoquímicas e fotofísicas mais adequadas para serem utilizados na TFD; eles são ativados com comprimentos de onda entre 600-800nm e, assim, conseguem ser excitados em planos mais profundos dos tecidos biológicos, apresentam elevado rendimento quântico na geração de ${ }^{1} \mathrm{O}_{2}$, maior seletividade tumoral e período de fotossensibilidade mais curto, além de serem tóxicos somente na presença da luz.

Dentre esses FS de segunda geração destacam-se as ftalocianinas. Este grupo de compostos possui propriedades interessantes, tais quais: grande variedade de estruturas químicas, penetração efetiva nos tecidos, absorbância em várias regiões, principalmente na janela fototerapêutica (ZIELICHOWSKA et alli. 2015), ou seja, dentro da faixa de comprimento de onda (600-800 nm) na qual a penetração da luz nos tecidos biológicos é aumentada, sem sofrer interferência dos cromóforos endógenos, presentes nos sistemas biológicos, que fazem com que a penetração de luz nos tecidos biológicos seja menor do que a luz incidente. Além disso, as ftalocianinas podem ter as suas propriedades fotofísicas e fotoquímicas moduladas ao serem associadas a metais como o zinco, silício, o alumínio e o cloro, de modo a melhorar a sua eficácia durante a sua fotossensibilização (TOMAZINI et alli, 2007 ).

Entretanto, esses fotossensibilizantes, principalmente os derivados de ftalocianinas, são altamente hidrofóbicos, o que gera entraves que comprometem a sua atuação como FS. Devido a esse caráter hidrofóbico, estas moléculas tendem a formar agregados moleculares que reduzem significativamente a eficiência na geração de espécies reativas. Para solucionar 
esse problema, os FS hidrofóbicos podem ser dispersos em carreadores de drogas, como as nanopartículas, que criam ambientes apolares que favorecem a dispersão destes FS e, por conseguinte, a geração de agentes oxidantes após a fotoativação dos fármacos. Ademais, a associação a nanocarreadores permite que os FS sejam administrados em indivíduos por via endovenosa. $\mathrm{O}$ encapsulamento de um FS não só permite aumentar a sua solubilidade em soluções aquosas, como também melhora a entrega do fármaco às células tumorais, reduzindo assim, os efeitos colaterais induzidos por ele, o número de doses a serem administradas, além de prolongar os intervalos entre elas (WOJTONISZAK et alli. 2013). Por isso, os fotossensibilizantes começaram a ser ligados a diferentes nanomateriais, constituindo assim os denominados fotossensibilizantes de terceira geração. Esses nanomateriais podem ser, entre outros, polímeros surfactantes. Desses, os copolímeros com porção hidrofílica de polioxietileno e porção hidrofóbica de polioxialquilenos ou de poliésteres têm atraído grande interesse como matrizes de liberação controlada de fármacos, sendo o copolímero Pluronic F127 interessante, pois é capaz de interagir com membranas biológicas e superfícies hidrofóbicas, e moléculas anfifílicas, além de poder inibir algumas bombas de efluxo de fármacos, em particular a glicoproteína-P, gpP, (WEl et alli, 2013).

Considerando que o fotossensibilizante Alumínio-Cloro-Ftalocianina é um fármaco que tem se mostrado eficaz na eliminação de células neoplásicas (TAPAJÓS et alli, 2008; BICALHO et alli, 2013; MUEHLMANN et alli, 2014) e que nanopartículas magnéticas podem ser utilizadas, na magnetohipertermia, em sistemas de contraste de imagem, e também como carreador de fármaco, é plausível acreditar que a associação desses compostos possa direcionar a 
Alumínio-Cloro-Ftalocianina até o tecido alvo e assim melhorar a eficácia da TFD mediada por esse fármaco no tratamento do câncer. Assim pesquisadores do INCT - Nanobiotecnologia, no qual este estudo está inserido, desenvolveram um nanossistema composto de nanopartículas magnéticas, majoritariamente de magnetita $\left(\mathrm{Fe}_{2} \mathrm{O}_{3}\right)$ e as revestiram com ácido oleico associado ao polímero Pluronic F-127 (PF-127) e com o fotossensibilizante Alumínio-Cloro Ftalocianina (AICIPC) adsorvido para ser utilizado na magnetohipertermia, na TFD e como agente de contraste de imagem em exames de ressonância magnética. 
Para que os índices de incidência e mortalidade por câncer possam ser reduzidos é fundamental a prevenção e detecção precoce da doença, além do desenvolvimento de terapias mais efetivas com o mínimo de efeitos adversos. Considerando isso, o Laboratório de Nanobiotecnologia da Universidade de Brasília, juntamente com os demais membros da Rede de Nanobiotecnologia, tem desenvolvido estudos visando o desenvolvimento de nanoestruturas biocompatíveis e eficientes em tratamentos do câncer. A possibilidade de se desenvolver terapias mais efetivas no tratamento do câncer por meio de novos materiais nanoestruturados justifica esta pesquisa. 
Considerando a necessidade de se desenvolver novos materiais que possam ser utilizados no tratamento do câncer de modo mais efetivo e com menos efeitos adversos, este estudo tem como objetivo geral analisar a eficácia de um novo material nanoestruturado constituído de nanopartículas de magnetita revestidas com uma monocamada de ácido oleico a qual está associado o polímero Pluronic F-127 com o fotossensibilizante Alumínio-CloroFtalocianina adsorvido, a ser utilizado na TFD.

Para tal foram estabelecidos os seguintes objetivos específicos:

- determinar a capacidade do fotossensibilizante Alumínio-CloroFtalocianina adsorvido ao novo nanomaterial em gerar oxigênio singleto, por meio do método de decaimento do Benzofurano;

- verificar a eficácia da TFD mediada pelo mediada pelo nanomaterial $\mathrm{Fe}_{2} \mathrm{O}_{3} / \mathrm{AO} / \mathrm{P}-\mathrm{F} 127-\mathrm{AlClFt}$ em linhagens celulares, tumorais ou não, por meio do ensaio de metabolização de brometo de 3 (4,5 dimetiltiazol-2il)-2,5-difenil-tetrazólio), denominado de ensaio do MTT;

- avaliar a incorporação do fotossensibilizante Alumínio-CloroFtalocianina adsorvido ao novo nanomaterial, por células tumorais ou não, por meio de um sistema de cromatografia líquida de alta eficiência e microscopia confocal;

- determinar o perfil de morte celular induzido pela TFD mediada pelo nanomaterial $\mathrm{Fe}_{2} \mathrm{O}_{3} / \mathrm{AO} / \mathrm{P}-\mathrm{F} 127-\mathrm{AlClFt}$ em linhagens celulares tumorais ou não, por meio de citometria de fluxo; 
- analisar o potencial elétrico de membranas mitocondriais de células submetidas à TFD mediada pelo nanomaterial $\mathrm{Fe}_{2} \mathrm{O}_{3} / \mathrm{AO} / \mathrm{P}-\mathrm{F} 127-$ AICIFt em linhagens celulares tumorais ou não, por meio de citometria de fluxo;

- determinar a fragmentação do DNA induzido pela TFD mediada pelo nanomaterial $\mathrm{Fe}_{2} \mathrm{O}_{3} / \mathrm{AO} / \mathrm{P}-\mathrm{F} 127-\mathrm{AlClFt}$ em linhagens celulares tumorais ou não, por meio de citometria de fluxo;

- avaliar em tempo real a dinâmica da proliferação celular das células sobreviventes à TFD mediada pelo nanomaterial $\mathrm{Fe}_{2} \mathrm{O}_{3} / \mathrm{AO} / \mathrm{P}-\mathrm{F} 127-$ AICIFt e de suas descendentes. 


\subsection{Amostra}

No presente estudo utilizou-se uma amostra composta por um fluído magnético constituído de nanopartículas de magnetita $\left(\mathrm{Fe}_{2} \mathrm{O}_{3}\right)$ revestidas com uma camada de ácido oleico ( $\mathrm{AO})$ a qual está associado o polímero Pluronic F127 (PF127) e com o fotossensibilizante Alumínio-Cloro Ftalocianina (AICIFt) adsorvido. Essa amostra, $\mathrm{Fe}_{2} \mathrm{O}_{3} / \mathrm{AO} / \mathrm{P}-\mathrm{F} 127-\mathrm{AlClFt}$, a qual foi denominada de NOP-AICIFt, foi sintetizada pelos professores Leonardo Giordano Paterno e Maria Aparecida Godoy Soler, respectivamente, dos Institutos de Química e Física, da Universidade de Brasília, utilizando-se para obtenção do núcleo magnético o método de decomposição térmica.

A caracterização física do nanossistema foi realizada por dispersão dinâmica de luz e microscopia de eletrônica de transmissão. A NOP, cuja concentração de ferro é igual 35, 6 mg/L, mostrou, por dispersão dinâmica de luz, diâmetro hidrodinâmico de $280,40 \pm 3,24 \mathrm{~nm}$ e por microscopia de eletrônica de transmissão diâmetro de 11,66 $\pm 1,78 \mathrm{~nm}$.

\subsection{Fonte de Diodo Emissor de Luz}

Para a irradiação da NOP-AICIFt foram utilizados bancos de 20 diodos emissores de luz LED modelo XL001WP01NRC660 (Shenzhen Sealand Optoelectronics Co. Ltd., China). O circuito de alimentação foi montado pelo professor Dr. Paulo Souza do Instituto de Física da Universidade de Brasília. O controle da corrente de alimentação capaz de garantir a estabilidade da iluminação foi realizado por um controlador RCD-24-0.35/W, Constant Current LED Driver (Recom Power, Inc., Alemanha). 


\subsection{Linhagens celulares}

Para determinar a eficácia da NOP-AICIFt na terapia fotodinâmica foram utilizadas, conforme ilustrado na Tabela 1, quatro linhagens celulares imortalizadas: (1) linhagem celular de fibroblastos não tumorais isolados de pele, células $\mathrm{NIH} / 3 \mathrm{~T} 3\left(\right.$ ATCC ${ }^{8} \mathrm{CRL}-1658^{\mathrm{TM}}$ ); (2) linhagem celular isolada de um adenocarcinoma de mama, células MCF-7 (Michigan Cancer Foundation-7, ATCC $\AA$, HTB-22 ${ }^{\text {TM }}$ ); (3) linhagem celular isolada de um carcinoma de pele, células A431, (A431 ATCC $\AA$ CRL-2592 ${ }^{\mathrm{TM}}$ ); (4) linhagem celular isolada de um carcinoma de útero, células HeLa NR1, (Hela Cells Transfected With Plasmid Psv2neonr101, ATCC $\AA$ CRL-13011 ${ }^{\mathrm{TM}}$ ).

Tabela 1. Linhagens celulares utilizadas no presente estudo.

\begin{tabular}{ll}
\hline Linhagem celular & Descrição \\
\hline NIH-3T3 & Fibroblastos não tumorais de derme \\
MCF-7 & Adenocarcinoma mamário \\
A431 & Carcinoma de pele \\
HeLa & Carcinoma cervical \\
\hline
\end{tabular}

A linhagem NIH-3T3, linhagem não tumoral, foi estabelecida a partir de fibroblastos de embriões de camundongo NIH Swiss. As células dessa linhagem, assim como a maioria das células não tumorais, apresentam inibição de contato; o contato físico entre elas dispara sinais químicos que inibem a mitose. Essa linhagem é muito utilizada em estudos de transfecção e transformação de DNA, pois as células incorporam DNA exógeno com alta eficiência (ATCC, 2015).

A linhagem MCF-7 é constituída de células de um adenocarcinoma mamário; essas células possuem cariótipo com número modal de 82 
cromossomos, apresentam receptores de estrógenos citoplasmáticos e resposta proliferativa a esses hormônios e apresentam também receptores de progesterona. Elas expressam o oncogene Wnt7B, gene que codifica uma proteína que participa da ativação da $\beta$-catenina. Uma vez ativada, a $\beta$ catenina entra no núcleo da célula e forma um complexo ativador da transcrição de genes envolvidos na proliferação celular. Além disso, essas células produzem receptores dos fatores de crescimento semelhante à insulina, IGFBP, (ATCC, 2015), que é um regulador do crescimento e da proliferação celular.

A linhagem A431 é constituída de células de um carcinoma de epiderme, essas células possuem número modal de cromossomos igual a 74 , não possuem o gene p53 funcional, mas expressam altos níveis do receptor do factor de crescimento epidérmico, EGFR, e por isso são muito sensíveis a estímulos mitogênicos, sendo assim muito utilizadas em estudos do ciclo celular e de vias de sinalização celular associadas ao câncer (ATCC, 2015).

A linhagem HeLa é constituída de células de um adenocarcinoma uterino, cujo número modal de cromossomos é 82 . Essas células contêm integradas ao seu genoma sequências gênicas do vírus do papiloma humano 18 (HPV-18); nelas a expressão do gene p53 é baixa, mas expressam Lisofosfatidilcolina, um lipídio envolvido na modulação da expressão de genes de proliferação e diferenciação celular (ATCC, 2015).

Todas essas linhagens celulares estão sendo mantidas no Laboratório de cultivo de células do Departamento de Genética e Morfologia do Instituto de Ciências Biológicas da Universidade de Brasília, UnB. 


\subsubsection{Manutenção e propagação das células}

Alíquotas de células das diferentes linhagens celulares, em concentração de $2 \times 10^{6}$ células $/ \mathrm{mL}$ eram retiradas do estoque de nitrogênio líquido. Quando descongeladas, as células eram transferidas para frascos de cultura de $25 \mathrm{~cm}^{2}$ (TPP, CHE) contendo meio de cultura Dulbecco's modified Eagle`s medium - DMEM (GIBCO, Auckland, NZ), suplementado com 10\% de soro fetal bovino (GIBCO, Auckland, NZ ou Gibco, USA) e 1\% de antibiótico PenStrep, composto por penicilina, $100 \mathrm{U} / \mathrm{ml}$, e estreptomicina, $100 \mu \mathrm{g} / \mathrm{ml}$ (GIBCO, Auckland, NZ ou Gibco, USA), e tamponado com bicarbonato de sódio (NaHCO3) (Sigma-Aldrich Co., USA), sendo o pH 7,4, ajustado pela adição de $\mathrm{HCL}$ e mantidas em incubadora, cuja atmosfera era de $5 \%$ de $\mathrm{CO}_{2}$, a umidade $80 \%$ e a temperatura de $37^{\circ} \mathrm{C}$.

Para o estabelecimento de subculturas, uma vez atingida $80-90 \%$ de confluência, as células eram desprendidas do fundo dos frascos de cultura por tratamento com solução de tripsina de 0,125\%/EDTA 0,02\% (Gibco, USA, ou GIBCO, Auckland, NZ), por três minutos a $37{ }^{\circ} \mathrm{C}$. Em seguida, de modo a inativar a enzima tripsina, eram acrescentados aos frascos de cultura contendo as células, três mililitros de meio de cultura. Essa solução era centrifugada (Excelsa baby/Fabricante Fanem, BRA) a $175 \mathrm{~g}$, por cinco minutos. Após o descarte do sobrenadante, as células eram então lavadas em um (1) $\mathrm{mL}$ de meio de cultura.

Antes de se repassar as células para novos frascos de cultura, fazia-se a contagem das células viáveis. Para tal, dez microlitros da suspensão celular eram adicionados a $90 \mu \mathrm{L}$ de solução de Azul Trypano (Sigma-Aldrich Co., USA), um corante capaz de penetrar em células que apresentam a membrana 
plasmática intacta, ou seja, em células viáveis. Dez microlitros desse preparado, suspensão celular e corante, eram então aplicados em um hemocitômetro de Neubauer (1/10 mm, Bright-line, Boeco Germany) para a contagem das células viáveis. A concentração de células viáveis era determinada considerando-se os quadrantes laterais e de acordo com a equação a seguir:

Número de células $/ \mathrm{mL}=$ Número de células contadas $\times$ Fator de diluição $\times 10^{4}$ Número de quadrantes contados

Após a contagem, $10^{4}$ células eram transferidas para novos frascos de cultura (TRP, Trasadingen, SUI) de $75 \mathrm{~cm}^{2}$ e incubadas nas mesmas condições descritas anteriormente.

\subsection{Determinação da dose de energia a ser aplicada na Terapia}

\section{Fotodinâmica}

$\mathrm{Na}$ terapia fotodinâmica a fonte de luz deve ser aplicada em potência adequada e com dose total de energia suficiente para excitar 0 fotossensibilizante. Por isso, fez-se necessário a realização de ensaios cujos resultados determinassem, não somente o tempo de irradiação, o que definiria a quantidade de energia luminosa a ser aplicada às células, mas também a distância em que a luz incidiria nas células.

Para esse ensaio, $5 \times 10^{3}$ células $/ \mathrm{mL}$ de cada uma das linhagens eram transferidas para microplacas de cultura com 96 poços e incubadas nas condições descritas no item 4.3.1. Após $24 \mathrm{~h}$ de incubação, o meio de cultura inicial era descartado e as células então submetidas a duas lavagens com 
$100 \mu \mathrm{L}$ de tampão fosfato salino (PBS). Em seguida, as células eram expostas novamente ao PBS e irradiadas com luz LED no comprimento de onde de 660nm: (1) com potência de $6,89 \mathrm{~mW} / \mathrm{cm}^{2}$, por 10,15 e 20 minutos o que corresponde, respectivamente, a doses de energia iguais a $4,13 \mathrm{~J} / \mathrm{cm}^{2}$, $6,20 \mathrm{~J} / \mathrm{cm}^{2}$ e $8,27 \mathrm{~J} / \mathrm{cm}^{2}$; (2) com potência de $13,71 \mathrm{~mW} / \mathrm{cm}^{2}$, por 10,15 e 20 minutos o que corresponde, respectivamente, a doses de energia iguais a $8,22 \mathrm{~J} / \mathrm{cm}^{2}, 12,34 \mathrm{~J} / \mathrm{cm}^{2}$ e $16,46 \mathrm{~J} / \mathrm{cm}^{2}$; (3) com potência de $39,48 \mathrm{~mW} / \mathrm{cm}^{2}$, por 10, 15 e 20 minutos o que corresponde, respectivamente, a doses de energia iguais a $23,70 \mathrm{~J} / \mathrm{cm}^{2}, 35,54 \mathrm{~J} / \mathrm{cm}^{2}$ e $47,38 \mathrm{~J} / \mathrm{cm}^{2}$, conforme ilustrado na Figura 2 .

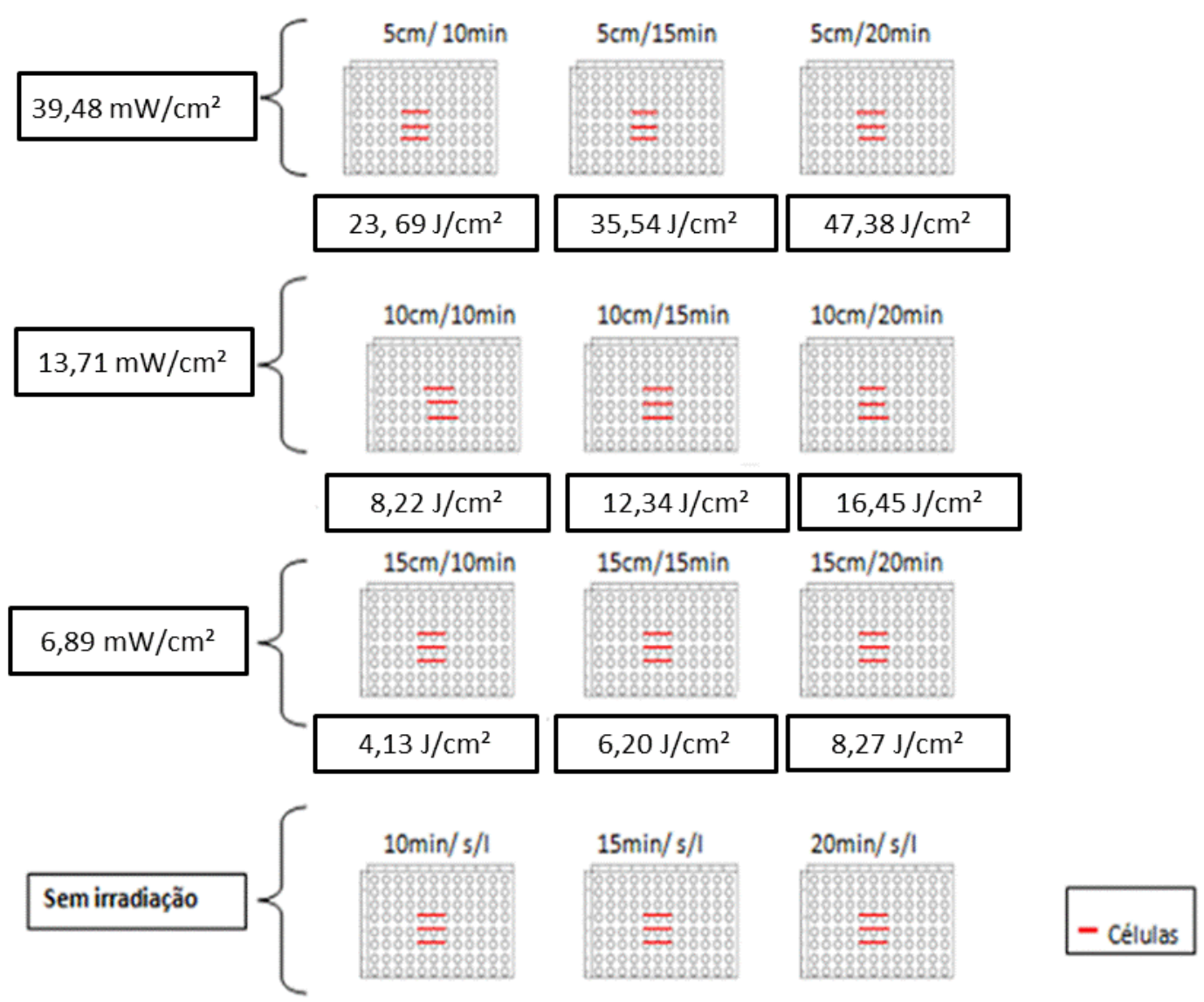

Figura 2. Desenho experimental para determinar a dose de energia $\left(\mathrm{J} / \mathrm{cm}^{2}\right)$ que as células suportariam sem comprometer a sua viabilidade na ausência da $\mathrm{Fe}_{2} \mathrm{O}_{3} / \mathrm{AO} / \mathrm{P}$. F127-AICIFt. 
Logo após a irradiação, o PBS era removido e as células, $5 \times 10^{3}$ células/poço, eram incubadas em microplacas de 96 poços, conforme descrito no item 4.3.1, para depois serem submetidas ao ensaio de metabolização de brometo de 3 (4,5 dimetiltiazol-2il)-2,5-difenil-tetrazólio), ensaio do MTT, com base no trabalho de Mosmann (1983).

O ensaio do MTT é um método colorimétrico sensível e quantitativo que avalia a metabolização celular e assim, a viabilidade e a proliferação celular (MOSMANN, 1983). Esse ensaio tem como base a capacidade das enzimas desidrogenases, presentes nas mitocôndrias, em converter o brometo de 3 (4,5 dimetiltiazol-2il)-2,5-difenil-tetrazólio), MTT, em um composto conhecido como formazan. Como a produção de formazan pode ser correlacionada à presença dessas desidrogenases ativas, esse ensaio é frequentemente utilizado para avaliar a citotoxicidade induzida por diferentes estímulos.

Assim, depois de 24 horas de incubação das células, o meio de cultura era substituído por $150 \mu \mathrm{L}$ de uma solução constituída de $15 \mu \mathrm{L}$ MTT e $135 \mu \mathrm{L}$ de meio de cultura e as células eram novamente incubadas a $37^{\circ} \mathrm{C}$, por duas horas. Após esse tempo, a solução contendo MTT era removida e $100 \mu \mathrm{L}$ de dimetil sulfóxido (DMSO, Mallinckrodt Chemicals, USA) eram adicionados para solubilizar os cristais de formazan. A quantificação do formazan era realizada pela medida do espectro de absorbância, com comprimento de onda de $595 \mathrm{~nm}$ em espectrofotômetro SpectraMax M2 (Molecular Devices, USA) conjugado à leitora de microplacas. Este ensaio foi realizado três vezes de forma independente, cada uma delas em triplicata. A quantidade de células vivas no grupo sem tratamento foi considerada como $100 \%$ de viabilidade. 


\subsection{Determinação da capacidade de Fe2O3/AO/P-F127-AICIFt em} gerar oxigênio singleto.

Este ensaio foi realizado de modo a determinar se o fotossensibilizante AICIFt adsorvido à NOP, quando irradiado com luz LED, mantinha a capacidade de induzir a produção de espécies reativas de oxigênio, o que é essencial para a terapia fotodinâmica. Essa produção de espécies reativas de oxigênio em consequência da reação fotodinâmica foi determinada por meio do método de degradação do benzofurano- ${ }^{-1} \mathrm{O}_{2}$-dependente. Segundo a metodologia adaptada por Spiller e colaboradoes (1998), o 1,3-difenilisobenzofurano (DBF) é uma molécula que reage pronta e irreversivelmente com $0{ }^{1} \mathrm{O}_{2}$, reduzindo a sua absorbância, cujo pico ocorre em 410nm. Assim, à medida que o benzofurano é decomposto pela geração de ${ }^{1} \mathrm{O}_{2}$, a sua absorbância é reduzida, sendo essa redução proporcional à quantidade de moléculas de ${ }^{1} \mathrm{O}_{2}$ geradas, o que permite a quantificação percentual desses compostos.

Para verificar a capacidade de geração de ${ }^{1} \mathrm{O}_{2}$ de NP-AICIFt, foi preparada uma solução de DBF (Sigma-Aldrich, Ltda., Alemanha) diluído em etanol, em uma concentração de $0,225 \mathrm{mg} / \mathrm{mL}$. Em seguida, a solução foi agitada em vórtex por dois minutos e levada ao banho ultrassônico até completa homogeneização da solução, que foi utilizada no máximo duas horas após seu preparo, devido à rápida degradação de DBF quando em solução.

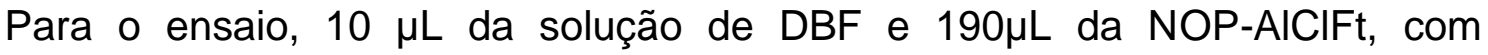
diferentes concentrações de AlCIFt $(0,02 \mu \mathrm{g} / \mathrm{mL} ; 0,04 \mu \mathrm{g} / \mathrm{mL} ; 0,09 \mu \mathrm{g} / \mathrm{mL})$ foram adicionados à placa de 96 poços e a degradação de DBF foi acompanhada após 30 ciclos de irradiação de 10 segundos, resultando na 
fluência de energia de $0,04 \mathrm{~J} / \mathrm{cm}^{2}$ por ciclo de irradiação. Após dez irradiações, a fluência total recebida pela amostra foi de $12 \mathrm{~J} / \mathrm{cm}^{2}$. A luz LED tinha comprimento de onda de 660 nm (MMOptics, São Carlos, SP), potência de $39,48 \mathrm{~mW} / \mathrm{cm}^{2}$.

Em seguida, a absorbância do benzofurano era mensurada em espectrofotômetro Endpoint, no comprimento de onda de 410nm. Como controles negativos eram realizadas leituras da absorbância da AICIFt dissolvida em PBS e em água, na concentração era de $0,09 \mu \mathrm{g} / \mathrm{mL}$, com e sem adição de benzofurano, antes e após a irradiação com o LED. Este ensaio foi realizado duas vezes de forma independente, cada uma delas em triplicata, à temperatura de $25{ }^{\circ} \mathrm{C}$, na presença de $\mathrm{O}_{2}$ atmosférico e na ausência de luz ambiente.

4.6. Determinação da eficácia da Terapia Fotodinâmica mediada pelo nanomaterial $\mathrm{Fe}_{2} \mathrm{O}_{3} / \mathrm{AO} / \mathrm{P}-\mathrm{F} 127-\mathrm{AICIFt}$

Este ensaio foi realizado com o intuito de avaliar a eficácia da amostra $\mathrm{Fe}_{2} \mathrm{O}_{3} / \mathrm{AO} / \mathrm{P}-\mathrm{F} 127-\mathrm{AICIFt}$ na terapia fotodinâmica. Para tal, $5 \times 10^{3}$ células eram plaqueadas em microplacas de 96 poços e incubadas nas condições descritas no item 4.3.1. Após 24 horas, o meio de cultura era descartado e às suspensões celulares era adicionado a NOP-AICIFt em diferentes concentrações de AICIFt: 0,000326 $\mu \mathrm{g} / \mathrm{mL}, 0,000732 \mu \mathrm{g} / \mathrm{mL}, 0,001465 \mu \mathrm{g} / \mathrm{mL}$, $0,00293 \mu \mathrm{g} / \mathrm{mL}, 0,005859 \mu \mathrm{g} / \mathrm{mL}, 0,011719 \mu \mathrm{g} / \mathrm{mL}, 0,023438 \mu \mathrm{g} / \mathrm{mL}, 0,046875$ $\mu \mathrm{g} / \mathrm{mL}, 0,09375 \mu \mathrm{g} / \mathrm{mL}, 0,18755 \mu \mathrm{g} / \mathrm{mL}, 0,375 \mu \mathrm{g} / \mathrm{mL}, 0,75 \mu \mathrm{g} / \mathrm{mL}$ e $1,5 \mu \mathrm{g} / \mathrm{mL}$. As microplacas eram então recobertas com folhas de alumínio, de modo a inibir a ação de qualquer tipo de irradiação, e incubadas nas condições descritas 
anteriormente. Depois de 15 minutos, o meio de cultura era descartado, $100 \mu \mathrm{L}$ de PBB eram adicionados às microplacas e as células eram então irradiadas, por 10 minutos, com luz LED com potência de $39,48 \mathrm{~mW} / \mathrm{cm}^{2}$, o que corresponde a dose total de energia igual a $23,70 \mathrm{~J} / \mathrm{cm}^{2}$. Em seguida, as células eram incubadas por mais 24 horas, quando eram então submetidas ao ensaio do MTT, conforme descrito no item 4.4. Como controles utilizaram-se células sem NOP-AICIFt irradiadas, e células com NOP-AICIFt, nas concentrações descritas acima, mas não irradiadas. Estes ensaios foram realizados três vezes de forma independente, cada uma delas em triplicata.

\subsection{Determinação do perfil de incorporação do fotossensibilizante}

\section{Alumínio-Cloro-Ftalocianina por células in vitro}

Considerando que na TFD as concentrações de NOP-AICIFt que reduziram a viabilidade das diversas linhagens estudadas foram diferentes decidiu-se verificar se essas diferenças estariam relacionadas ao padrão de incorporação da AICIFt pelas células. Para tal, realizaram-se dois ensaios, um para determinar a taxa de incorporação de AICIFt pelas células, por meio do método de cromatografia líquida de alta eficiência (CLAE), e outro para determinar a localização celular da AICIFt, por meio de microscopia confocal.

4.7.1 Determinação da taxa de incorporação do fotossensibilizante Alumínio-Cloro-Ftalocianina por células in vitro, em sistema de cromatografia líquida de alta eficiência

Para este ensaio foram plaqueadas, aproximadamente, $7 \times 10^{4}$ células/poço em microplacas de 12 poços e incubadas nas mesmas condições que as descritas no item 4.3.1. Depois de 24 horas, o meio de cultura era 
descartado e substituído por um (1) mL de PBS contendo NOP-AICIFt, cujas concentrações AlCIFt eram de $0,02 \mu \mathrm{g} / \mathrm{mL} ; 0,04 \mu \mathrm{g} / \mathrm{mL}$ e $0,09 \mu \mathrm{g} / \mathrm{mL}$. Como controle eram utilizadas células submetidas à AICIFt livre na concentração de $0,09 \mu \mathrm{g} / \mathrm{mL}$. A Tabela 2 ilustra os grupos experimentais utilizados neste ensaio, ensaio esse que foi realizado duas vezes, de forma independente, cada uma delas em triplicata. Depois de quinze minutos, as células eram lavadas com um (1) $\mathrm{mL}$ de PBS e, em seguida lisadas com $800 \mu \mathrm{L}$ de solução de extração, constituída de $89 \%$ etanol, $10 \%$ de DMSO e $1 \%$ de ácido acético.

Tabela 2. Grupos experimentais utilizados para determinar a taxa de incorporação e o padrão de distribuição intracelular do fotossensibilizante Alumínio-Cloro-Ftalocianina em células, in vitro, determinados, respectivamente, por meio de um sistema de cromatografia líquida de alta eficiência e por microscopia confocal.

\begin{tabular}{ll}
\hline Grupo & AICIFt $(\mu \mathrm{g} / \mathrm{mL})$ \\
\hline NOP-AICIFt/0,02 & 0,02 \\
NOP- AICIFt/0,04 & 0,04 \\
NOP- AICIFt/0,09 & 0,09 \\
AICIFt - livre & 0,09
\end{tabular}

As amostras eram filtradas e levadas para análise em um equipamento cromatográfico (Shimadzu-Prominence) constituído por desgaseificador em linha (Modelo DGU 20A5), módulo de distribuição de solvente (modelo LC20AT), injetor automático (modelo SIL-20AHT), forno de coluna (Modelo CTO20A), detector de fluorescência (modelo RF-10AXL) e controlador do sistema CBM-20A. A coluna utilizada foi a de fase reversa C8 Vydac $(25 \times 0,4 \mathrm{~cm}, 5 \mu \mathrm{m}$ de tamanho de partícula) (Separations Group, Ltd., Deeside, Inglaterra) com pré-coluna (0,4 cm, 5,0 $\mu \mathrm{m}$ de tamanho de partícula) (Separations Group, Ltd., 
Deeside, Inglaterra). A fase móvel foi obtida a partir da mistura de $0,12 \%$ de TFA em água Milli-Q (bomba A) e metanol (bomba B) com proporção 40:60 (v:v), rendendo uma fase móvel isocrática. Medições fluorimétricas foram realizadas em célula de fluxo de $12 \mu \mathrm{L}$ com os comprimentos de onda de 600 675 nm de excitação e emissão, respectivamente. O volume de injeção foi de 5 $\mu \mathrm{L}$ e a taxa de fluxo durante os ensaios foi de $1 \mathrm{~mL} / \mathrm{min}$ a uma pressão de trabalho de $120 \mathrm{kgf} / \mathrm{cm}^{2}$. A análise foi realizada com o forno de coluna a $30 \stackrel{\circ}{\circ}$.

Para o processamento dos dados e identificação de parâmetros cromatográficos utilizou-se o software LCsolution (Shimadzu, Tóquio, Japão).

4.7.2 Análise do padrão de distribuição intracelular do fotossensibilizante Alumínio-Cloro Ftalocianina por células in vitro, por meio de microscopia confocal

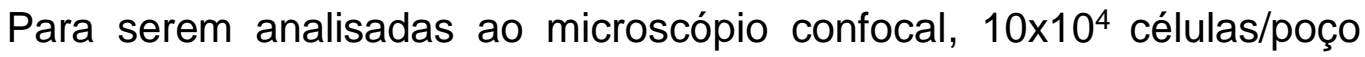
foram plaqueadas em microplacas de 12 poços, contendo cada um deles uma lamínula de microscopia $(15 \times 15 \mathrm{~mm})$ e incubadas nas mesmas condições descritas anteriormente. Após 24 horas, o meio de cultura era descartado e substituído por um (1) mL de PBS contendo NOP-AICIFt, cujas concentrações de AICIFt eram iguais a 0,02 $\mu \mathrm{g} / \mathrm{mL} ; 0,04 \mu \mathrm{g} / \mathrm{mL}$ e $0,09 \mu \mathrm{g} / \mathrm{mL}$. Depois de quinze minutos, as células eram lavadas duas vezes com um (1) $\mathrm{mL}$ de PBS e fixadas com paraformaldeído a 4,0\%, durante 15 minutos. Depois desse tempo as células eram lavadas com um (1) $\mathrm{mL}$ de PBS, sendo essa lavagem repetida por três vezes. Em seguida, adicionava-se $500 \mu \mathrm{L}$ de uma solução constituída de DAPI (4'6'-diamidino-2-fenilindol) e PBS $(1 \mathrm{mg} / \mathrm{mL})$, onde as células permaneciam por cinco minutos, quando então eram lavadas com PBS. Depois 
disso, as lamínulas eram retiradas das microplacas e dispostas em lâminas de microscopia (18 x $18 \mathrm{~mm}$ ), às quais se adicionava $5 \mu \mathrm{L}$ de antifade, uma substância que oferece maior resistência à fotodegradação e causa pouca ou nenhuma extinção do sinal fluorescente. As células eram visualizadas ao microscópio confocal (Leica, TCS SP5). Como controle eram utilizadas células submetidas à AICIFt livre na concentração de $0,09 \mu \mathrm{g} / \mathrm{mL}$. Os grupos experimentais utilizados neste ensaio são os mesmo que estão na Tabela 2. Este ensaio foi realizado duas vezes de forma independente, cada uma delas em triplicata.

\subsection{Determinação do perfil de morte celular induzido pela terapia} fotodinâmica mediada pelo nanomaterial $\mathrm{Fe}_{2} \mathrm{O}_{3} / \mathrm{AO} / \mathrm{P}-\mathrm{F} 127-\mathrm{AICIFt}$

Para determinar o perfil de morte celular induzido pela terapia fotodinâmica mediada pelo nanomaterial Fe2O3/AO/P-F127-AlCIFt as células foram submetidas ao ensaio de Anexina-V/FITC que permite, dentro de uma população, determinar a porcentagem de células em apoptose. Durante apoptose as células modificam a estrutura de suas membranas plasmáticas, deslocando o fosfolipídeo fosfatidilserina (PS) do interior da membrana plasmática para o ambiente externo. Desse modo, a Anexina $\mathrm{V}$, uma proteína dependente de cálcio que tem uma grande afinidade por PS, pode se ligar seletivamente a PS e assim servir para identificar células apoptóticas. A conjugação do corante Isotiocianato de Fluoresceína (FITC) à Anexina V permite identificar e quantificar as células apoptóticas por meio da citometria de fluxo. A utilização concomitante com o marcador nuclear fluorescente iodeto de 
propídio (PI), por sua vez, torna possível verificar as alterações características do processo de necrose.

Para a realização deste ensaio, células das quatro linhagens eram cultivadas em microplacas de cultura de 12 poços, na concentração de $5 \times 10^{5}$ célula/poço, nas mesmas condições descritas no item 4.3.1. Após 24 horas, o meio de cultura era descartado e substituído por um (1) mL de PBS contendo NOP-AICIFt, cujas concentrações de AICIFt eram 0,04 e 0,09 $\mu \mathrm{g} / \mathrm{mL}$. Depois de 15 minutos, o meio de cultura era descartado, $100 \mu \mathrm{L}$ de PBS eram adicionados às microplacas e as células eram então irradiadas, por dez minutos, com luz LED, com potencia $39,48 \mathrm{~mW} / \mathrm{cm}^{2}$ o que corresponde- a dose total de energia igual a $23,70 \mathrm{~J} / \mathrm{cm}^{2}$ e novamente incubadas.

Vinte e quatro horas depois, as células eram retiradas da incubadora, o sobrenadante era coletado e armazenado, as células lavadas com um (1) mL de PBS e então desprendidas do fundo do frasco por tratamento com $300 \mu \mathrm{L}$ de uma solução de tripsina de 0,125\%/EDTA 0,02\% (Gibco, USA, ou GIBCO, Auckland, NZ), por três minutos a $37^{\circ} \mathrm{C}$. Para inativar a enzima tripsina, eram adicionados à suspensão celular $700 \mu \mathrm{L}$ do sobrenadante previamente coletado e armazenado. Essa solução era centrifugada (Excelsa baby/Fabricante Fanem, BRA) a $175 \mathrm{~g}$ por três minutos e deixada à temperatura ambiente, mas ao abrigo da luz, por 15 minutos. Após a inativação da tripsina, as células eram centrifugadas a $175 \mathrm{~g}$ (Excelsa baby/Fabricante Fanem, BRA), por três minutos e então ressuspensas em $400 \mu \mathrm{L}$ de tampão de ligação de Anexina fornecido pelo Kit Apotarget® (Invitrogen, Carsbad, CA, USA). A essas suspensões de células foram adicionados cinco microlitros de Anexina-V conjugada com isotiocianato de fluoresceína - Anexina-V/FITC - e 
$10 \mu \mathrm{L}$ de iodeto de propídeo, ou somente $5 \mu \mathrm{L}$ de Anexina- $\mathrm{V}$ conjugada com isotiocianato de fluoresceína - Anexina-V/FITC, ou ainda $10 \mu \mathrm{L}$ de iodeto de propídeo. A Tabela 3 ilustra os grupos experimentais utilizados neste ensaio. Em seguida, as células eram levadas ao citômetro de fluxo Cyflow Space (Partec, Germany), em que a fluorescência dos compostos era capturada nos canais FITC-PI (515-530nm) Esse ensaio foi realizado em duplicata. Os dados foram capturados pelo software FloMax 2.4 e analisados utilizando-se o software FlowJo® 7.6.3.

Tabela 3. Grupos experimentais utilizados para determinar o perfil de morte celular induzido pela terapia fotodinâmica mediada pelo nanomaterial $\mathrm{Fe}_{2} \mathrm{O}_{3} / \mathrm{AO} / \mathrm{P}-\mathrm{F} 127-\mathrm{AlClFt}$ e irradiadas com densidade de energia igual 23,70 $\mathrm{J} / \mathrm{cm}^{2}$, por meio do ensaio de Anexina-V/FITC

\begin{tabular}{lll}
\hline Grupo & AlClFt $(\mu \mathrm{g} / \mathrm{mL})$ & Corante \\
\hline Controle & - & - \\
Controle/ Anexina-V/FITC & - & Anexina-V/FITC \\
Controle/PI & - & $\mathrm{PI}$ \\
Controle/Anexina-V/FITC e PI & - & Anexina-V/FITC e PI \\
NOP-AICIFt/0,04 & 0,04 & - \\
NOP-AICIFt/0,04/ Anexina-V/FITC e PI & 0,04 & Anexina-V/FITC e PI \\
NOP-AICIFt/0,09 & 0,09 & - \\
NOP-AICIFt/0,09/ Anexina-V/FITC e PI & 0,09 & Anexina-V/FITC e PI \\
\hline
\end{tabular}

4.9 Análise do potencial elétrico de membranas mitocondriais de células submetidas à terapia fotodinâmica mediada pelo nanomaterial $\mathrm{Fe}_{2} \mathrm{O}_{3} / \mathrm{AO} / \mathrm{P}-\mathrm{F} 127-\mathrm{AICIFt}$

O potencial elétrico de membranas mitocondriais de células submetidas à terapia fotodinâmica mediada pelo nanomaterial $\mathrm{Fe}_{2} \mathrm{O}_{3} / \mathrm{AO} / \mathrm{P}-\mathrm{F} 127-\mathrm{AlCIFt}$ foi avaliado pelo monitoramento da captação da sonda fluorescente Rodamina 123 (Sigma-Aldrich), um fluorocromo catiônico que é atraído pelo elevado potencial 
elétrico negativo presente na membrana mitocondrial, incorporando-se no interior destas organelas. Alterações na integridade mitocondrial podem ser detectadas através do aumento da florescência verde citosólica, indicando uma difusão da Rh-123 da mitocôndria para o citosol (JOHNSON et alli, 1980).

Para esse ensaio, as células foram cultivadas em microplacas de cultura de 12 poços, na concentração de $5 \times 10^{5}$ célula/poço, e depois de 24 horas submetidas à terapia fotodinâmica, conforme descrito no item anterior.

Vinte e quatro horas depois da terapia fotodinâmica, o sobrenadante era coletado e armazenado, as células lavadas com um (1) mL de PBS e então desprendidas do fundo do frasco por tratamento com $300 \mu \mathrm{L}$ de uma solução de tripsina de 0,125\% / EDTA 0,02\% (Gibco, USA, ou GIBCO, Auckland, NZ), por três minutos a $37^{\circ} \mathrm{C}$. Para inativar a enzima tripsina, eram adicionados à suspensão celular $700 \mu \mathrm{L}$ do sobrenadante previamente coletado e armazenado. Essa solução era centrifugada (Excelsa baby/Fabricante Fanem, BRA) a $175 \mathrm{~g}$ por três minutos e deixadas à temperatura ambiente, mas ao abrigo da luz, por 15 minutos. Após a inativação da tripsina, as células eram centrifugadas a $175 \mathrm{~g}$ (Excelsa baby/Fabricante Fanem, BRA), por três minutos e então ressuspensas em $500 \mu \mathrm{L}$ de uma solução Rodamina 123 (Rho123) e deixadas à temperatura ambiente, mas ao abrigo da luz, por 15 minutos. Depois desse tempo, esse preparado era novamente centrifugado a $175 \mathrm{~g}$, por três minutos quando depois se descartava o sobrenadante. As células eram então ressuspensas em $500 \mu \mathrm{L}$ de PBS e levadas ao citômetro de fluxo Cyflow Space (Partec, Germany), FlowMax para avaliação da fluorescência. A Tabela 4 demonstra os grupos experimentais utilizados neste ensaio. 
Tabela 4. Grupos experimentais utilizados para avaliar o potencial de membranas mitocondriais de células submetidas à terapia fotodinâmica mediada pelo nanomaterial $\mathrm{y}$-Fe2O3/AO/P-F127-AICIFt e irradiadas com densidade de energia igual $23,70 \mathrm{~J} / \mathrm{cm}^{2}$, por meio do ensaio de Rodamina

\begin{tabular}{lll}
\hline Grupo & AlCIFt $(\mu \mathrm{g} / \mathrm{mL})$ & Corante \\
\hline Controle & - & - \\
Controle/Rho123 & - & Rodamina \\
NOP-AICIFt/0,04 & 0,04 & - \\
NOP-AICIFt/0,04/Rho123 & 0,04 & Rodamina \\
NOP-AICIFt/0,09 & 0,09 & - \\
NOP-AICIFt/0,09/Rho123 & 0,09 & Rodamina \\
\hline
\end{tabular}

Esse ensaio foi realizado em duplicata. Os dados foram capturados pelo software FloMax 2.4 e analisados utilizando-se o software FlowJo® 7.6.3.

\subsection{Análise da fragmentação do DNA de células submetidas à terapia fotodinâmica mediada pela $\mathrm{Fe}_{2} \mathrm{O}_{3} / \mathrm{AO} / \mathrm{P}-\mathrm{F} 127-\mathrm{AICIFt}$}

Para a análise da fragmentação do DNA, células das quatro linhagens eram cultivadas em microplacas de cultura de 12 poços, na concentração de $5 \times 10^{5}$ célula/poço, nas mesmas condições descritas no item 4.3.1. Após 24 horas, o meio de cultura era descartado e substituído por um (1) mL de PBS contendo NOP-AICIFt, cujas concentrações de AICIFt eram 0,04 e 0,09 $\mu \mathrm{g} / \mathrm{mL}$. Depois de 15 minutos, o meio de cultura era descartado, $100 \mu \mathrm{L}$ de PBS eram adicionados às microplacas e as células eram então irradiadas, por 10 minutos, com luz LED, com potencia $39,48 \mathrm{~mW} / \mathrm{cm} 2$ o que corresponde a dose total de energia igual a $23,70 \mathrm{~J} / \mathrm{cm}^{2}$ e novamente incubadas.

Vinte e quatro horas depois, o sobrenadante era coletado e armazenado, as células lavadas com um (1) $\mathrm{mL}$ de PBS e então desprendidas do fundo do frasco por tratamento com $300 \mu \mathrm{L}$ de uma solução de tripsina, 0,125\%, EDTA 
0,02\% (Gibco, USA, ou GIBCO, Auckland, NZ), conforme descrito anteriormente.

Após a inativação da tripsina, as células eram centrifugadas a $175 \mathrm{~g}$ (Excelsa baby/Fabricante Fanem, BRA), por três minutos e então ressuspensas em $200 \mu \mathrm{L}$ de uma solução tamponada de lise $(0,1 \%$ citrato de sódio, $0,1 \%$ Triton X-100, $20 \mu \mathrm{g} / \mathrm{mL}$ iodeto de propídio, $50 \mu \mathrm{g} / \mathrm{mL}$ RNase A, pH 7,4), a $37^{\circ} \mathrm{C}$ e em ambiente ausente de luminosidade. Uma vez expostas ao tampão de lise, as células tem as suas membranas rompidas e o núcleo exposto, o que facilita a ligação do iodeto de propídeo ao DNA e consequentemente a detecção e a quantificação desta estrutura em cada célula, pois as moléculas de DNA íntegras emitem maior fluorescência do que as moléculas de DNA fragmentado.

Após trinta minutos no tampão de lise, as células eram levadas ao citômetro de fluxo Cyflow Space (Partec, Germany) para a leitura no comprimento de onda de 560 a 580nm (canal FL-2). A Tabela 5 demonstra os grupos experimentais utilizados para analisar a fragmentação do DNA de células submetidas à terapia fotodinâmica. Esse ensaio foi realizado em duplicata.

Tabela 5: Grupos experimentais utilizados para analisar a fragmentação do DNA em células submetidas à terapia fotodinâmica mediada pela $\mathrm{Fe}_{2} \mathrm{O}_{3} / \mathrm{AO} / \mathrm{P}$ F127- e irradiadas sob densidade de energia igual $23,70 \mathrm{~J} / \mathrm{cm}^{2}$, por meio de citometria de fluxo.

\begin{tabular}{ll}
\hline Grupos & AlClFt $(\mu \mathrm{g} / \mathrm{ml})$ \\
\hline Controle & - \\
NOP $/ 0,04$ sem células & 0,04 \\
NOP $/ 0,09$ sem células & 0,09 \\
NOP $/ 0,04$ com células & 0,04 \\
NOP $/ 0,09$ com células & 0,09
\end{tabular}




\subsection{Dinâmica da proliferação celular das células sobreviventes a} terapia fotodinâmica mediada pela $\mathrm{Fe}_{2} \mathrm{O}_{3} / \mathrm{AO} / \mathrm{P}-\mathrm{F} 127-\mathrm{AICIFt}$.

Este ensaio foi realizado de modo a avaliar se as células que sobreviveram à terapia fotodinâmica mantinham a capacidade proliferativa. Para isso, utilizou-se o sistema $x$ CELLigence ${ }^{\mathrm{TM}}$ (Roche/ACEA). Esse sistema abrange três estações integradas, um instrumento de RTCA que é utilizado dentro de uma incubadora de cultura de células e que utiliza placas com microelétrodos de ouro para monitorar a proliferação celular em tempo real, por meio da detecção automatizada do índice de biomassa celular.

Para esse ensaio, primeiramente eram colocados $100 \mu \mathrm{L}$ de meio de cultura em placas E-Plate16 (Roche/ACEA) para obter os valores basais. Uma vez estabilizado o sistema, $5 \times 10^{3}$ células de cada uma das linhagens celulares, sem tratamento algum, foram colocadas em placas E-Plate16 (Roche/ACEA), às quais se adicionou $100 \mu \mathrm{L}$ de meio de cultura. As placas foram mantidas por 30 minutos no fluxo laminar, para a decantação das células e depois no equipamento de RTCA (ver Figura 3). O conjunto era levado à incubadora, cuja atmosfera era de $5 \%$ de $\mathrm{CO}_{2}$, a umidade $80 \%$ e a temperatura de $37^{\circ} \mathrm{C}$.

A proliferação celular era analisada durante $24 \mathrm{~h}$. Depois desse tempo o sistema de detecção era interrompido, o meio de cultura desprezado e $100 \mu \mathrm{L}$ de NOP-AICIFt, cujas concentrações de AICIFt eram de 0,02 $\mu \mathrm{g} / \mathrm{mL}, 0,04$ $\mu \mathrm{g} / \mathrm{mL}$ e $0,09 \mu \mathrm{g} / \mathrm{mL}$, eram adicionados às placas que foram novamente incubadas por 15 minutos. Depois disso, as células eram submetidas à terapia fotodinâmica, conforme descrito anteriormente. 

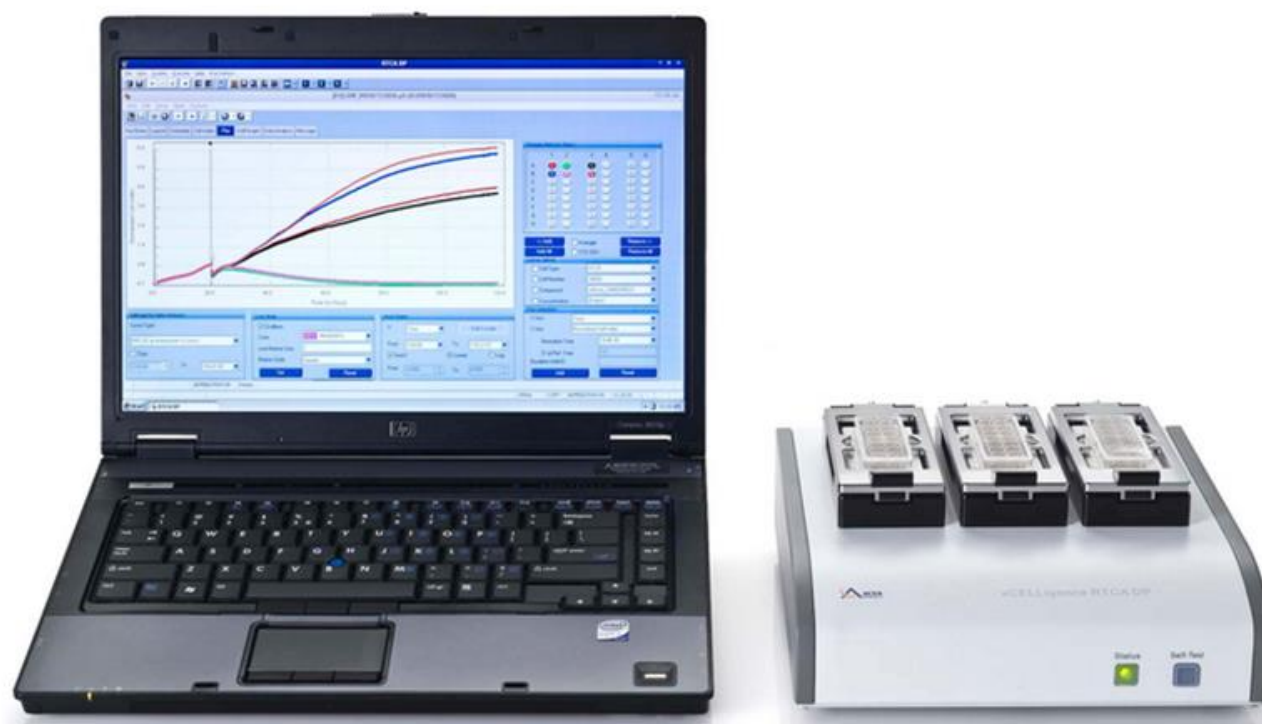

Figura 3. Equipamento de análise da dinâmica de proliferação celular em tempo real (Real Time Cell Analysis - RTCA), acessado de http://www.aceabio.com, em maio de 2015.

Após a terapia fotodinâmica, o PBS era descartado e adicionado $200 \mu \mathrm{L}$ de meio de cultivo. As placas foram colocadas novamente no instrumento de RTCA que foi levado à estufa. A dinâmica da proliferação celular foi analisada por 120 horas, ou seja, por cinco dias. Como controle utilizaram-se células sem NOP-AICIFt. Os grupos experimentais utilizados neste ensaio são os mesmos que foram utilizados no ensaio de fragmentação do DNA, ou seja, os descritos na Tabela 6. Este ensaio foi realizado em triplicata. Os dados de proliferação celular foram analisados utilizando-se o software RTCA (Roche/ACEA). 
Tabela 6: Grupos experimentais utilizados para analisar a dinâmica de proliferação das células submetidas à terapia fotodinâmica mediada pela $\mathrm{Fe} 2 \mathrm{O} / \mathrm{AO} / \mathrm{P}-\mathrm{F} 127-\mathrm{AlClFt}$ e irradiadas sob densidade de energia igual 23,70 $\mathrm{J} / \mathrm{cm}^{2}$.

\begin{tabular}{ll}
\hline Grupos & AlCIFt $(\mu \mathrm{g} / \mathrm{ml})$ \\
\hline Controle & - \\
NOP-AlCIFt /0,02 & 0,02 \\
NOP-AICIFt /0,04 & 0,04 \\
NOP-AICIFt /0,09 & 0,09
\end{tabular}

\subsection{2 - Análises estatísticas}

Os dados obtidos nos diferentes ensaios foram submetidos à análise de variância (ANOVA). Nos casos em que foram detectadas diferenças entre os grupos, foi aplicado o teste de Tukey com nível de significância de $p<0,01$. A análise a tabulação dos dados foi realizado por meio do software GraphPad Prism® 5. 
No presente estudo,com o intuito de avaliar a efetividade do nanossistema $\mathrm{Fe}_{2} \mathrm{O}_{3} / \mathrm{AO} / \mathrm{P}-\mathrm{F} 127-\mathrm{AlClFt}$,NOP-AICIFt, na terapia fotodinâmica, foram realizados diferentes ensaios cujos resultados estão descritos a seguir.

Uma das abordagens experimentais inicialmente planejadas foi determinar a densidade de energia,na ausência da NOP-AICIFt,a ser aplicada às células das quatro linhagens. Para tal, células das linhagens NIH-3T3, MCF7, A431 e HeLa foram irradiadas com diferentes densidades de energia: $4,13 \mathrm{~J} / \mathrm{cm}^{2} ; 6,20 \mathrm{~J} / \mathrm{cm}^{2} ; 8,22 \mathrm{~J} / \mathrm{cm}^{2} ; 8,27 \mathrm{~J} / \mathrm{cm}^{2} ; 12,34 \mathrm{~J} / \mathrm{cm}^{2} ; 23,70 \mathrm{~J} / \mathrm{cm}^{2}, 16,45$ $\mathrm{J} / \mathrm{cm}^{2} ; 35,54 \mathrm{~J} / \mathrm{cm}^{2}$ e 47,38 J/cm². Os resultados estão ilustrados na Figura 4.

Como ilustradona Figura $4 \mathrm{~A}$, as células da linhagem NIH-3T3 apresentaram redução da viabilidade quando irradiadas com densidades de energia iguais a $23,70 \mathrm{~J} / \mathrm{cm}^{2}$ e $35,54 \mathrm{~J} / \mathrm{cm}^{2}$.

Já as células da linhagem MCF7 (Figura 4B) apresentaram redução da viabilidade quando a irradiação era com densidades de energia iguais a4,13J/ $\mathrm{cm}^{2}, \quad 6,20 \mathrm{~J} / \mathrm{cm}^{2}$ e $35,54 \mathrm{~J} / \mathrm{cm}^{2}$, mas apresentaram aumento da viabilidade quando irradiadas com densidade de energia igual a12,34J/ $/ \mathrm{cm}^{2}$.

As células da linhagem A431(Figura 4C) apresentaram aumentoda viabilidade quando irradiadas com dose de energias iguais a $4,13 \mathrm{~J} / \mathrm{cm}^{2}$, $6,20 \mathrm{~J} / \mathrm{cm}^{2}, 8,27 \mathrm{~J} / \mathrm{cm}^{2} \mathrm{e} 23,70 \mathrm{~J} / \mathrm{cm}^{2}$.

Entretanto, nenhuma das densidades de energia aplicadas às células da linhagem HeLa afetou-lhes a viabilidade (Figura 4D). 
A

Linhagem Celular - NIH-3T3

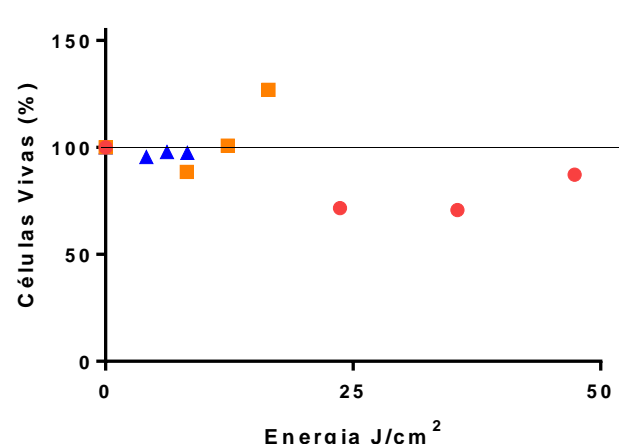

C

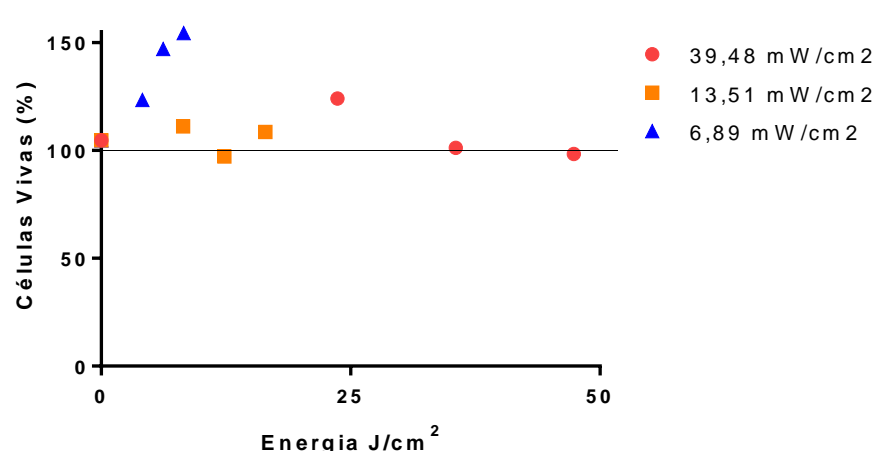

B

- $39,48 \mathrm{~mW} / \mathrm{cm} 2$

- $13,51 \mathrm{~mW} / \mathrm{cm}^{2}$

- $6,89 \mathrm{~mW} / \mathrm{cm} 2$

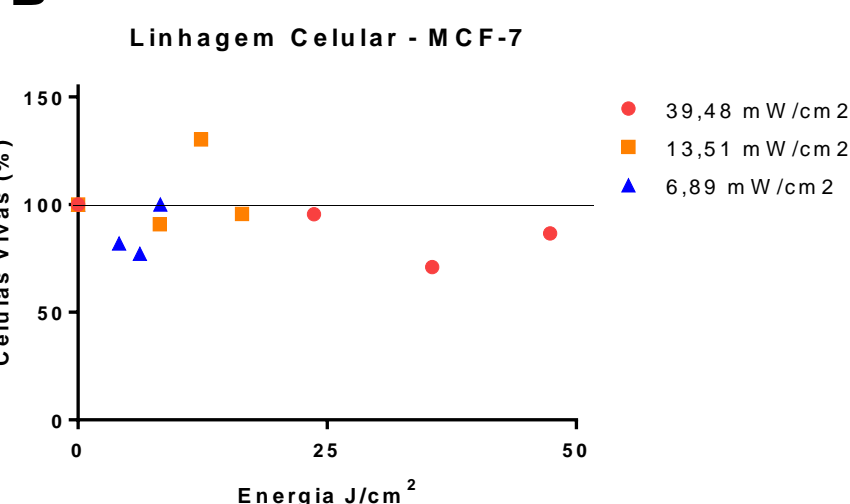

D

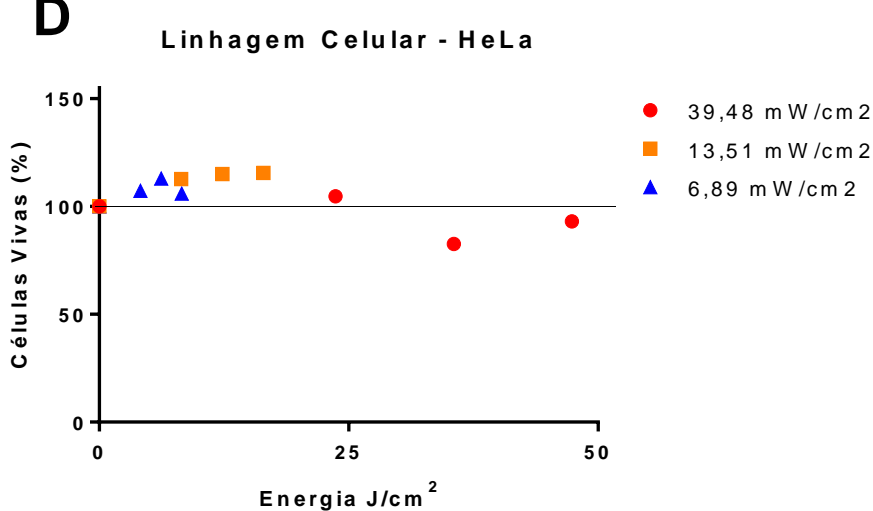

Figura 4. Viabilidade, determinada por meio do ensaio de metabolização de brometo de 3 (4,5 dimetiltiazol-2il)-2,5-difenil-tetrazólio), das diferentes linhagens celulares após irradiação comdiferentes densidades de energia na ausência da $\mathrm{Fe}_{2} \mathrm{O}_{3} / \mathrm{AO} / \mathrm{P}-\mathrm{F} 127-\mathrm{AlClFt}$. 
A etapa seguinte do trabalho consistiu em determinar a capacidade do fotossensibilizante AICIFtem induzir a produção de oxigênio singleto, ${ }^{1} \mathrm{O}_{2}$, quando adsorvido a NOP. Isso foi feito por meio do método de degradação do Benzofurano dependente de oxigênio. Os resultados estão expressos na Figura 5.Nessa figura pode-se observar que ocorre decaimentoda absorbância do Benzofurano ao longo do tempo, o que indica que o mesmo foi oxidado como consequência do aumento de $^{1} \mathrm{O}_{2}$, gerado a partir da reação fotodinâmica, sendo que quando a AICIFt está adsorvida a NOP e é irradiada ela transfere mais energia do que quando não associada a NOP.

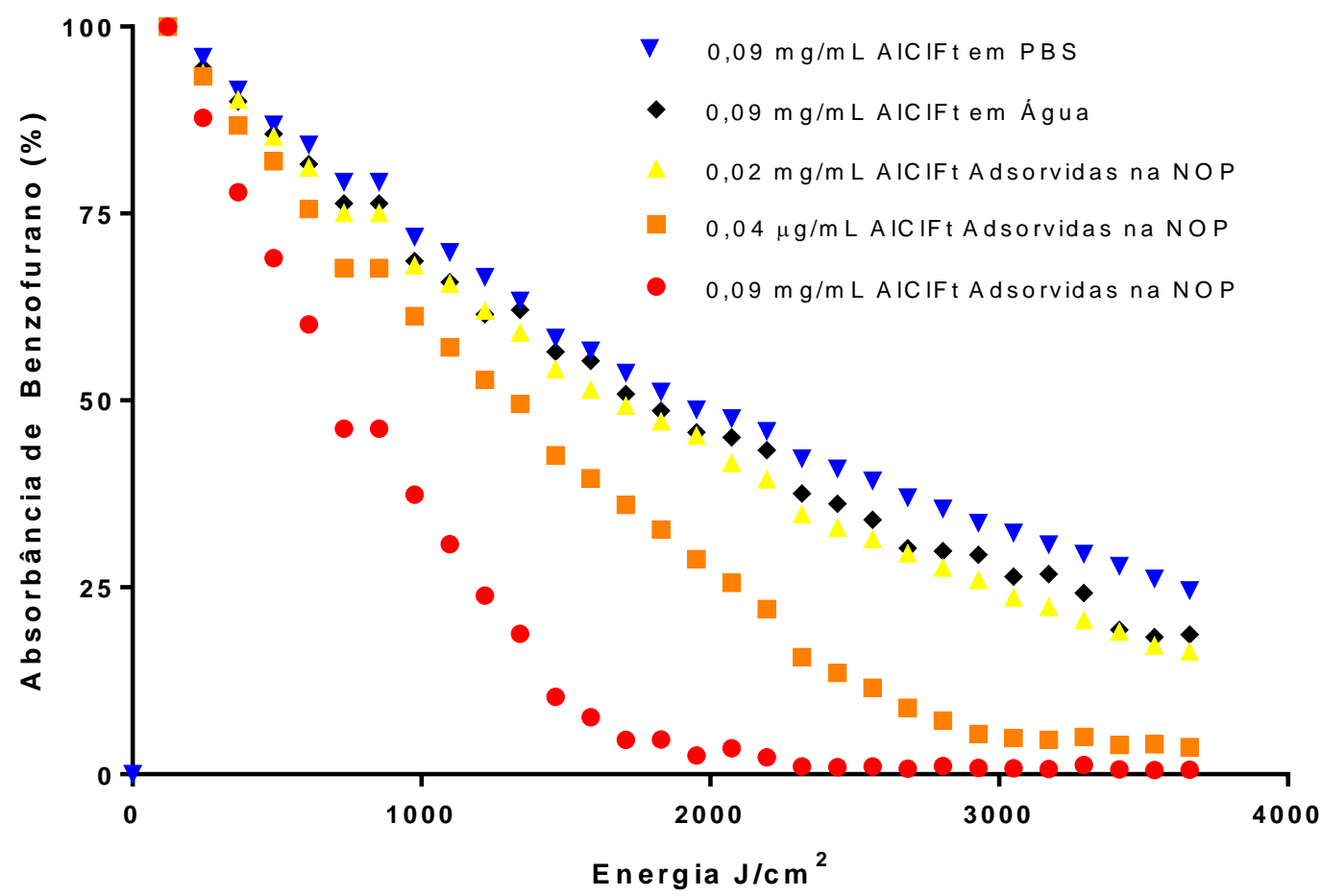

Figura 5. Espectros de absorbância da AICIFt, adsorvida ou não a um fluido magnético constituído de nanopartículas de magnetita revestidas com uma monocamada de ácido oleico associado ao polímero Pluronic F-127 ( $\left.\mathrm{Fe}_{2} \mathrm{O}_{3} / \mathrm{AO} / \mathrm{P}-\mathrm{F} 127-\mathrm{AICIFt}\right)$, mensurada pela degradação do Benzofurano após irradiação por fonte diodo emissor de luz $(\lambda=660 \mathrm{~nm})$ comdiferentes densidades de energia $\left(\mathrm{J} / \mathrm{cm}^{2}\right)$, na presença de oxigênio.

Uma vez que o fotossensibilizante AICIFtquando adsorvido a NOP mantinha a capacidade de induzir a produção de ${ }^{1} \mathrm{O}_{2}$, realizou-se então um ensaio do MTTpara avaliar a sua eficácia na terapia fotodinâmica. Para a 
análise dos dados, a média de células vivas no grupo sem tratamento algum, ou seja, sem NOP-AICIFt e sem irradiação foi considerada 100\%. Os resultados estão expressos nas Figuras 6, 7, 8 e 9.

Nessas figuras observa-se que a NOP-AlCIFtquando não irradiada (colunas pretas) não é tóxica para as células das linhagens NIH-3T3(Figura 6) quando as concentrações deAICIFtsão iguais a: $0,011719 \mu \mathrm{g} / \mathrm{mL}(99,29 \%$ de células vivas), $0,375 \mu \mathrm{g} / \mathrm{mL}$ (90,97\% de células vivas), $0,75 \mu \mathrm{g} / \mathrm{mL}$ (97,84\% de células vivas) e $1,5 \mu \mathrm{g} / \mathrm{mL}$ (104,08\% de células vivas),nem para as da linhagem MCF-7 (Figura 7) quando as concentrações deAICIFtsão iguais a: 0,000732 $\mu \mathrm{g} / \mathrm{mL}$ (95,57\% de células vivas), 0,0014648 $5 \mu \mathrm{g} / \mathrm{mL}(94,41 \%$ de células vivas), $0,00293 \mu \mathrm{g} / \mathrm{mL}$ (96,09\% de células vivas), $0,005859 \mu \mathrm{g} / \mathrm{mL}(95,40 \%$ de células vivas).Entretanto, para as células das linhagens A431(Figura 8) e HeLa (Figura 9), qualquer que seja a concentração deAICIFt adsorvida, a viabilidade não foi reduzida por NOP-AICIFt.

Vale ressaltar que, em determinadas concentrações de AICIFt, a NOPAICIFt induziu proliferação celularnas linhagens MCF-7 e A431.A linhagem MCF-7(Figura 6) apresentou aumento de 12,15\%, 11,50\%, 8,88\%, 14,81\%, $13,29 \%$, e $12,14 \%$ de proliferação celular quando submetida àNOP-AICIFt cujas concentrações deAICIFt adsorvidaeram,respectivamente, $0,023438 \mu \mathrm{g} / \mathrm{mL}, 0,046875 \mu \mathrm{g} / \mathrm{mL}, 0,09375 \mu \mathrm{g} / \mathrm{mL}, 0,18755 \mu \mathrm{g} / \mathrm{mL}, 0,375 \mu \mathrm{g} / \mathrm{mL}$ e $0,75 \mu \mathrm{g} / \mathrm{mL}$. A linhagemA431(Figura 7) apresentou aumento de $17,48 \%$, 20,55\%, 32,35\%e 26,60\% da proliferação celular quando submetidas à NOPAICIFt que continha concentrações deAICIFt adsorvida igual a0,18755 $\mu \mathrm{g} / \mathrm{mL}$, $0,375 \mu \mathrm{g} / \mathrm{mL}, 0,75 \mu \mathrm{g} / \mathrm{mL}$ e $1,5 \mu \mathrm{g} / \mathrm{mL}$, respectivamente. 


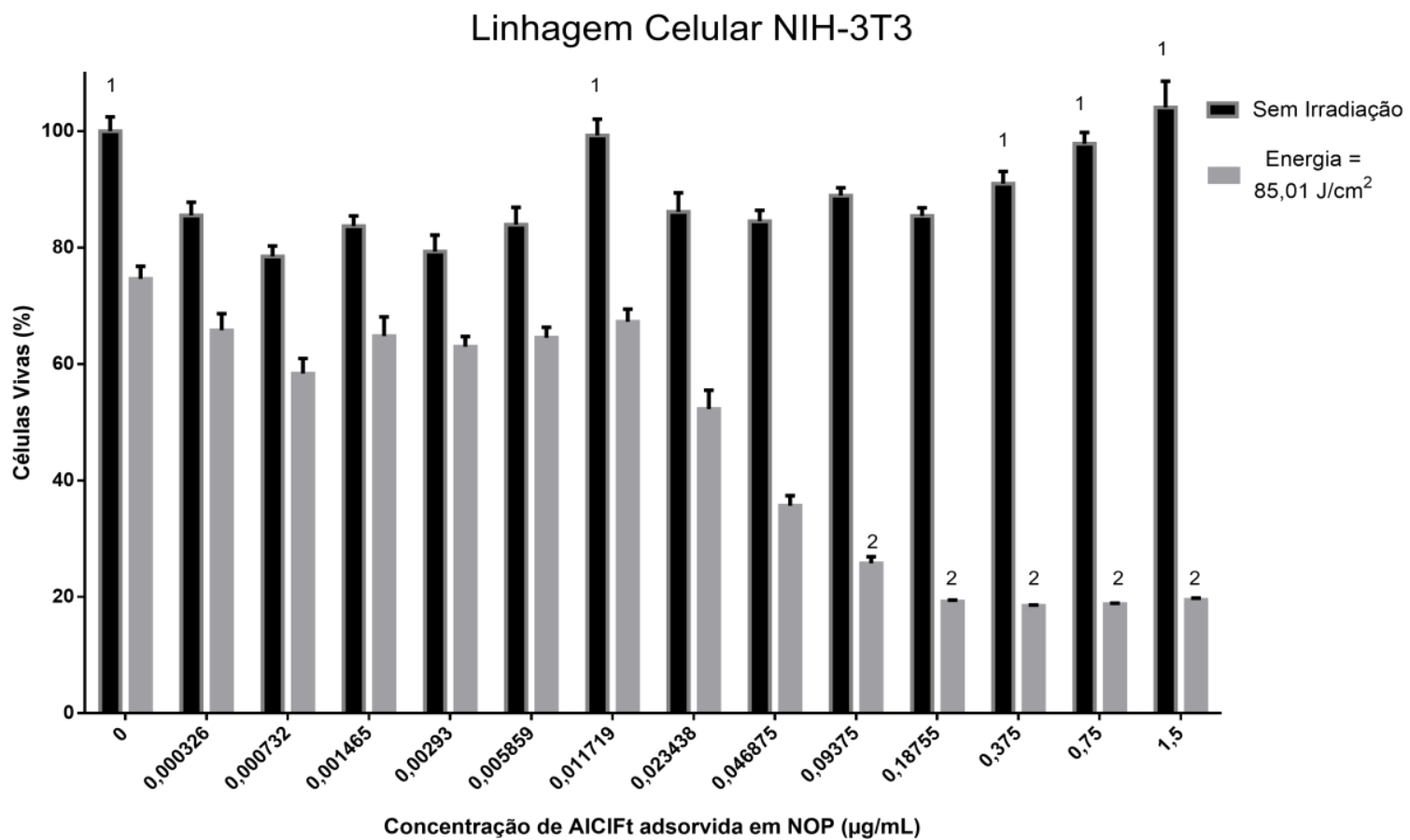

Figura 6. Citotoxicidade induzida pela terapia fotodinâmica mediada pela AICIFt adsorvida $\mathrm{aFe}_{2} \mathrm{O}_{3} / \mathrm{AO} / \mathrm{P}-\mathrm{F} 127$ com diferentes concentrações de AICIFt adsorvida, em células da linhagem $\mathrm{NIH}-3 \mathrm{~T} 3$ irradiadas com densidade de energia igual a23,70J/ $\mathrm{cm}^{2}$, determinada por meio do ensaio de metabolização de brometo de 3 (4,5 dimetiltiazol-2il)-2,5-difenil-tetrazólio).

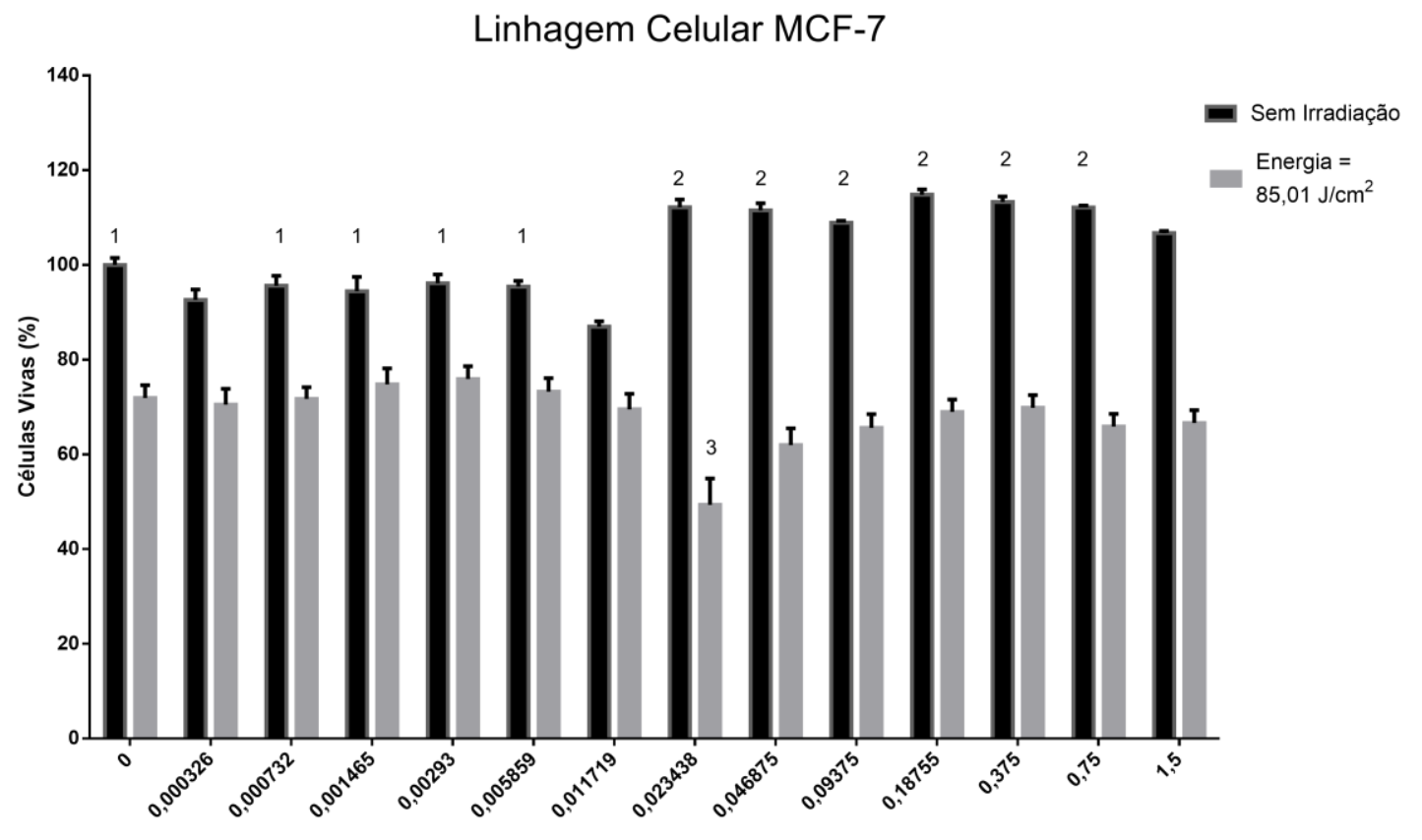

Figura 7. Citotoxicidade induzida pela terapia fotodinâmica mediada pela AICIFt adsorvida à $\mathrm{Fe}_{2} \mathrm{O}_{3} / \mathrm{AO} / \mathrm{P}-\mathrm{F} 127$ com diferentes concentrações de AICIFt adsorvida, em células da linhagem MCF-7 irradiadas com densidade de energia igual a23,70 $/ \mathrm{cm}^{2}$, determinada por meio do ensaio de metabolização de brometo de 3 (4,5 dimetiltiazol-2il)-2,5-difenil-tetrazólio). 


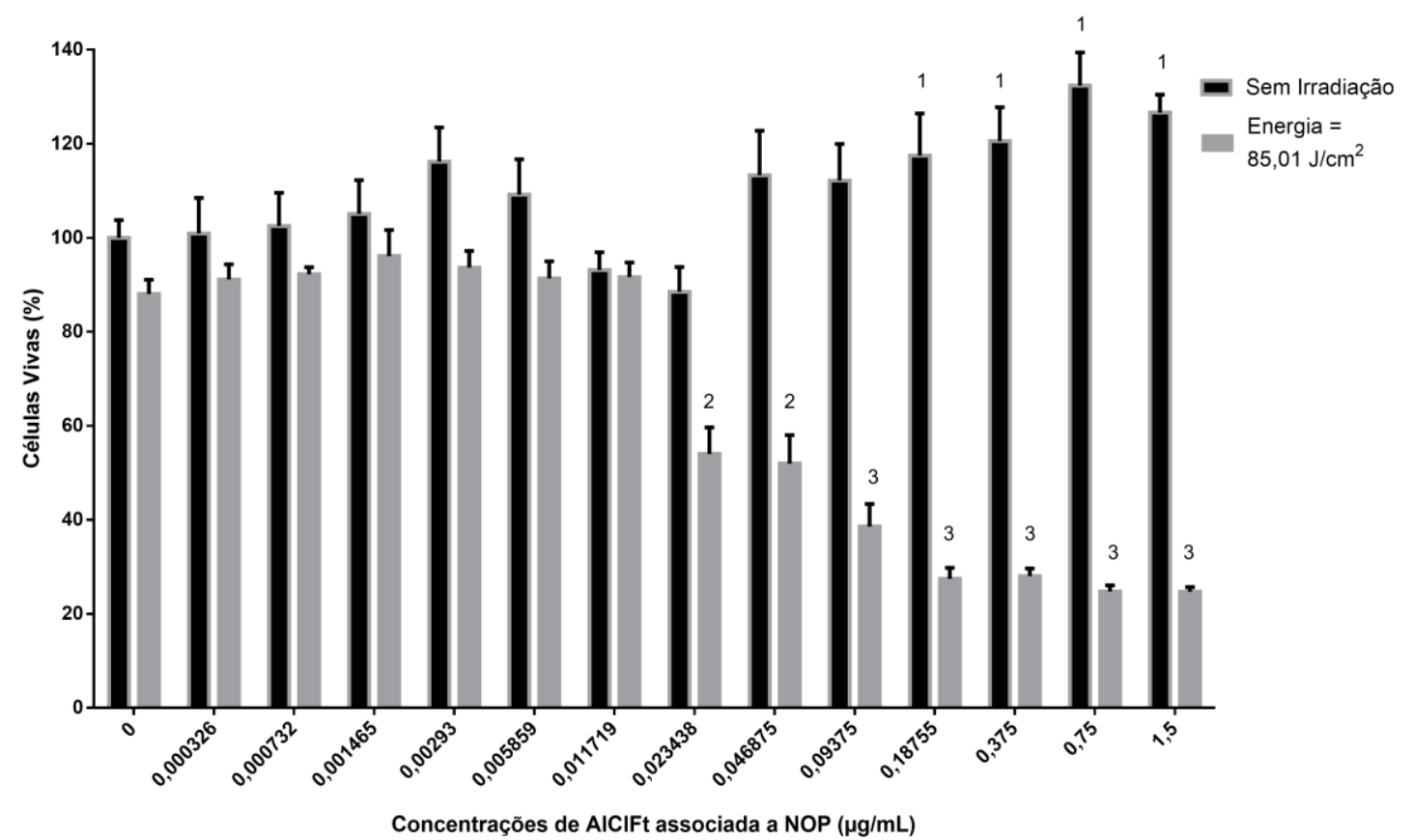

Figura 8. Citotoxicidade induzida pela terapia fotodinâmica mediada pela AICIFt adsorvida à $\mathrm{Fe}_{2} \mathrm{O}_{3} / \mathrm{AO} / \mathrm{P}-\mathrm{F} 127$ com diferentes concentrações de AICIFt adsorvida, em células da linhagem A431 irradiadas com densidade de energia igual a23,70J/ $\mathrm{cm}^{2}$, determinada por meio do ensaio de metabolização de brometo de 3 (4,5 dimetiltiazol-2il)-2,5-difenil-tetrazólio).

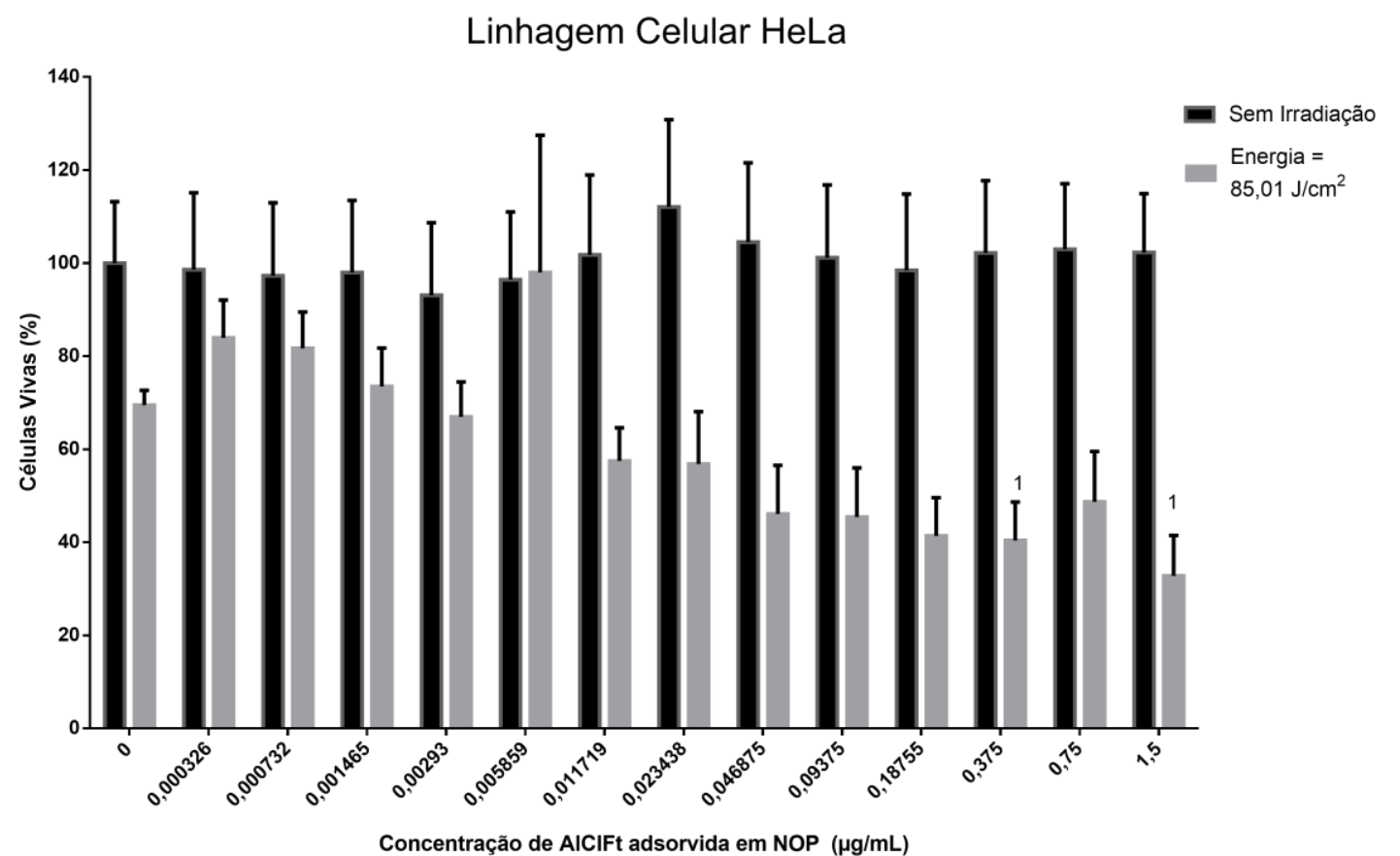

Figura 9. Citotoxicidade induzida pela terapia fotodinâmica mediada pela AICIFt adsorvida à $\mathrm{Fe}_{2} \mathrm{O}_{3} / \mathrm{AO} / \mathrm{P}-\mathrm{F} 127$ com diferentes concentrações de AICIFt adsorvida, em células da linhagem HeLa irradiadas com densidade de energia igual a23,70J/ $\mathrm{cm}^{2}$, determinada por meio do ensaio de metabolização de brometo de 3 (4,5 dimetiltiazol-2il)-2,5-difenil-tetrazólio). 
As mesmas figuras $(6,7,8$ e 9) mostram que quando a NOP-AlCIFt é irradiada,com densidade de energia de $23,70 \mathrm{~J} / \mathrm{cm}^{2}$, ou seja, quando se efetua a terapia fotodinâmica (colunas cinza), as célulasde todas as linhagensanalisadas apresentam redução da viabilidade, viabilidade essa que variadeacordo com a concentração de AICIFt e da linhagem celular.

Nas linhagensNIH-3T3(Figuras 6) e MCF-7 (Figura 7),a redução da viabilidade celular ocorreu quando as células foram submetidas à terapia fotodinâmica, qualquer que tenha sido a concentração de AICIFt adsorvida a NOP, sendo quepara as células NIH-3T3, a terapia fotodinâmica foi mais eficaz quando as concentrações de AlCIFteram iguais ou superiores $0,09375 \mu \mathrm{g} / \mathrm{mL}$. Nessas concentrações a taxa de redução da viabilidade das células nãoé significativamente diferente.Já para as células da linhagem MCF-7, a terapia fotodinâmica foi mais eficaz quando aNOP continha $0,0234375 \mu \mathrm{g} / \mathrm{mLAICIFt}$ adsorvida, concentração essa que levoua redução de $62,80 \%$ da viabilidade.

Com relação à linhagem A431, observa-se na Figura 8 que as células somente apresentaram redução da viabilidade quando submetidas à terapia fotodinâmicaem que a concentração de AICIFt adsorvida a NOPera igual ou superior $0,0234375 \mu \mathrm{g} / \mathrm{mL}$, sendo quequando a concentraçãode AICIFtera igual a $0,09375 \mu \mathrm{g} / \mathrm{mL}$,a taxa de viabilidade célula não difere daquela induzida pela maior concentração que é $1,5 \mu \mathrm{g} / \mathrm{mL}$.

Já as células da linhagem HeLa (Figura 9) apresentaram redução da viabilidade quando submetidas à terapia fotodinâmica mediada pela NOPAICIFt, cuja concentração de AICIFt adsorvida era igual a $0,0375 \mu \mathrm{g} / \mathrm{mL}$ e $1,5 \mu \mathrm{g} / \mathrm{mL}$. 
As diferenças apresentadas pelas quatro linhagens quanto à sensibilidade frente àterapia fotodinâmica podem ser elucidadasmelhor na Figura 10. Nela pode-seobservar a CL50, ou seja, a concentração de AICIFt capaz de eliminar $50 \%$ de células de cada uma das quatro populações de células. Assim sendo, alinhagem NIH-3T3 foia que mostrou maior sensibilidade ao tratamento, pois atingiu a redução de $50 \%$ da sua população antes que qualquer outra linhagem, sendo seguida pela linhagem A431, HeLa e finalmente pela linhagem MCF-7 linhagem. Nessa mesma figura, observa-se que as linhagens NIH-3T3, A431,HeLa e MCF-7apresentam, respectivamente, CL5oigual a 0,0108 $\mu \mathrm{g} / \mathrm{mL}, 0,0702 \mu \mathrm{g} / \mathrm{mL}, 0,1048 \mu \mathrm{g} / \mathrm{mL}$ e 2,474 $\mu \mathrm{g} / \mathrm{mL}$.

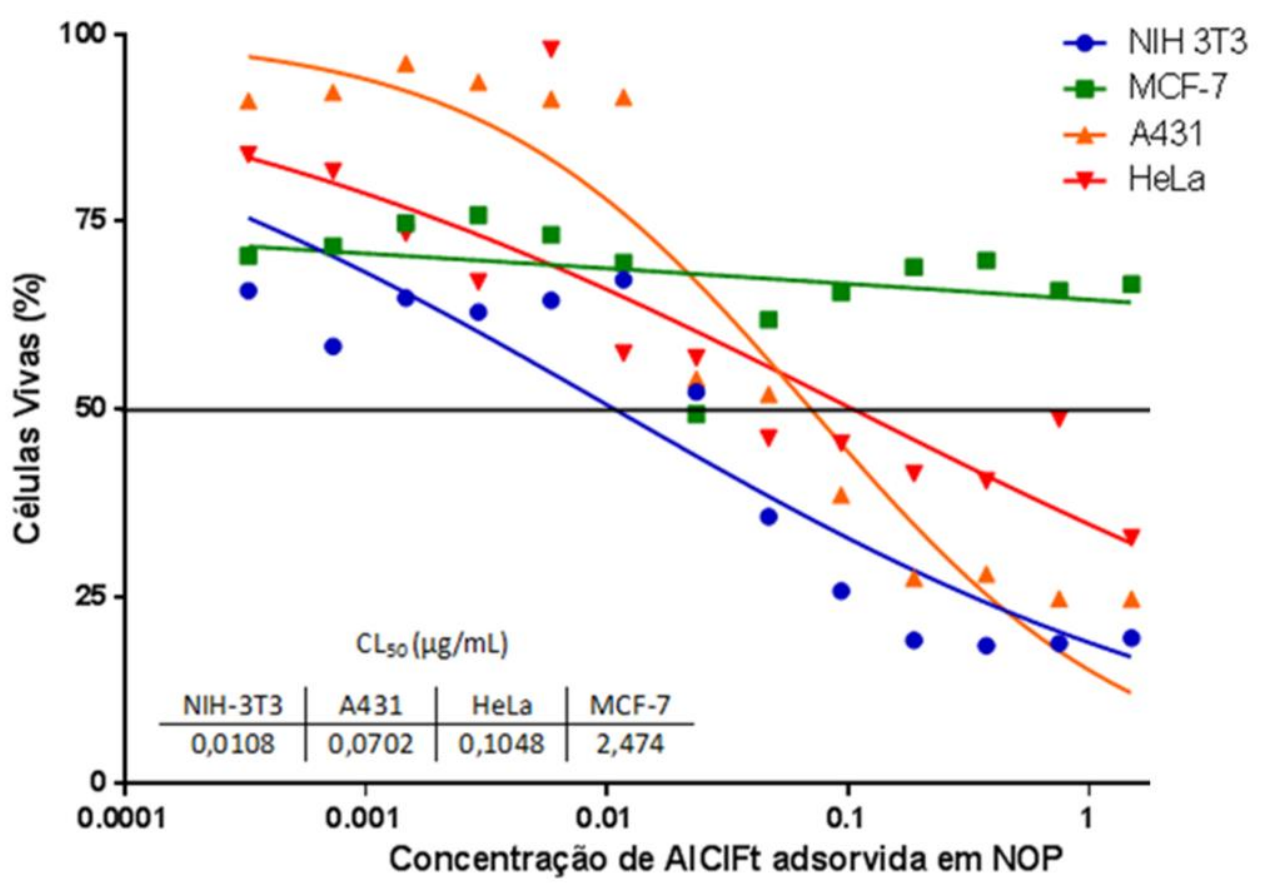

Figura 10. Concentração de AIClFtadsorvida $\mathrm{aFe}_{2} \mathrm{O}_{3} / \mathrm{AO} / \mathrm{P}-\mathrm{F} 127$ capaz de eliminar $50 \%$ das células de uma população das linhagens celulares NIH-3T3, A431, HeLa e MCF-7 submetidas à terapia fotodinâmica e irradiadas com densidade de energia igual a $23,70 \mathrm{~J} / \mathrm{cm}^{2}$ 
Considerando que a CL50 varia de linhagem para linhagem, decidiu-se verificar se essas diferenças estariam relacionadas à quantidade de $\mathrm{AICIFt}$ incorporada pelas células ou a sua localização dentro das células.Para tal, utilizou-se somente NOP cujas concentrações de AICIFt adsorvida eram iguais a $0,02 \mu \mathrm{g} / \mathrm{mL}, 0,04 \mu \mathrm{g} / \mathrm{mL}, 0,09 \mu \mathrm{g} / \mathrm{mL}$, isso porque com essas concentrações é que a terapia fotodinâmicamostrou-se mais eficaz. Os resultados estão expressos na Figura 11.

Nessa figura observa-se que quando se considera a mesma linhagem, a quantidade deAICIFt incorporada pelas célulasindepende da concentração de AlCIFt adicionada ao meio, esteja ela adsorvida ou não à NOP, e que as células da linhagem NIH-3T3 incorporaram mais AICIFt (44,37\%) do que as células HeLa $(21,10 \%)$ quando foram exportas a NOP com $0,02 \mu \mathrm{g} / \mathrm{ml}$ de AICIFt adsorvida.

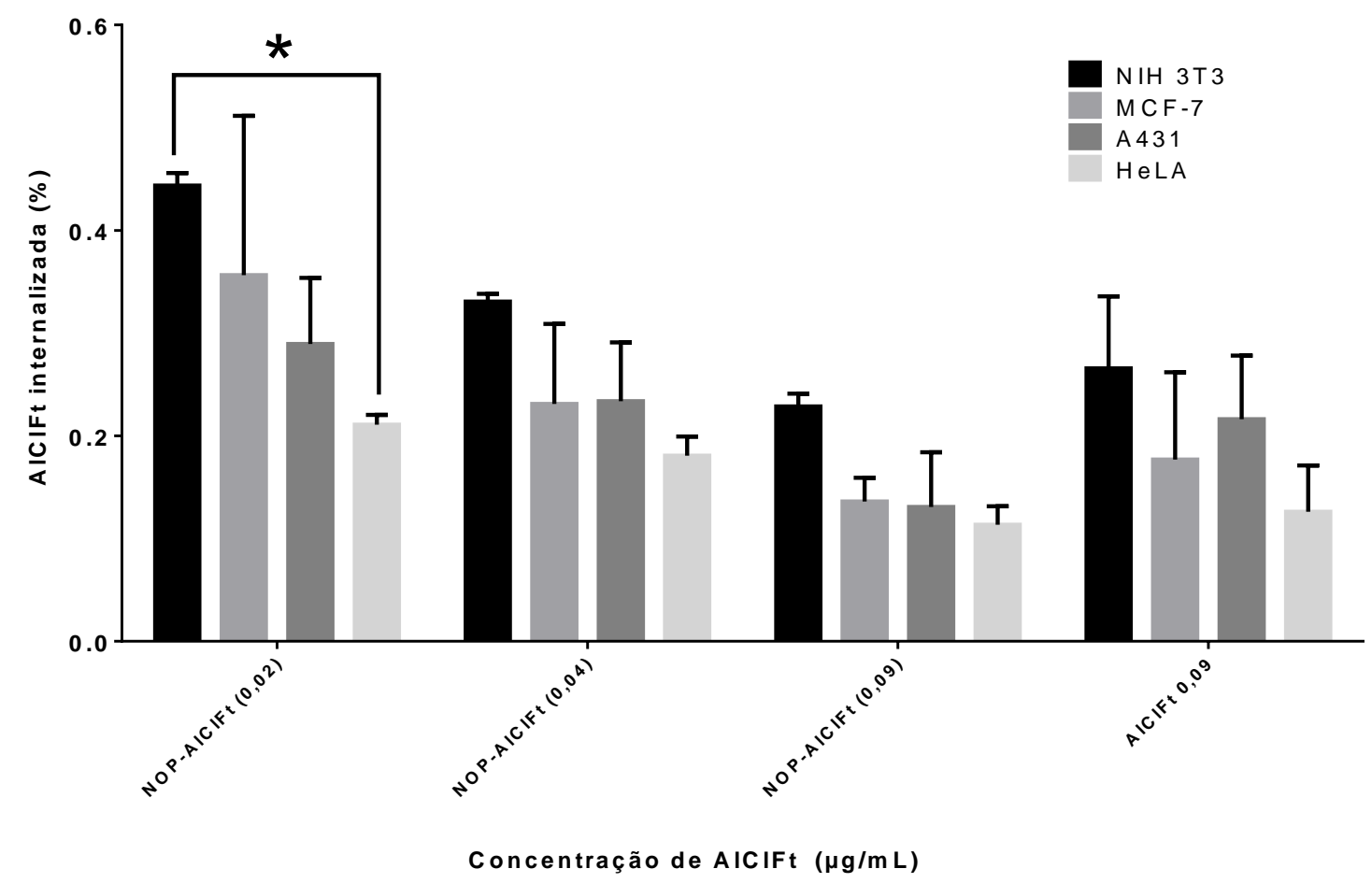

Figura 11.Taxa de incorporação de $\mathrm{AlClFt}$ livre ou adsorvida $\mathrm{aFe}_{2} \mathrm{O}_{3} / \mathrm{AO} / \mathrm{P}-\mathrm{F} 127$ nas células das linhagens NIH-3T3, MCF-7, A431 e HeLa, por meio do método de cromatografia líquida de alta eficiência. $\left(^{*}\right)$ denota diferença significativa entre as linhagens células.Dados estão representados como média \pm EPM para duplicata. 
A AICIFt livre ou adsorvida a NOP,quando incorporada pelas células das diferentes linhagens, é acumulada no citoplasma (Figura 12), qualquer que seja a linhagem celular.
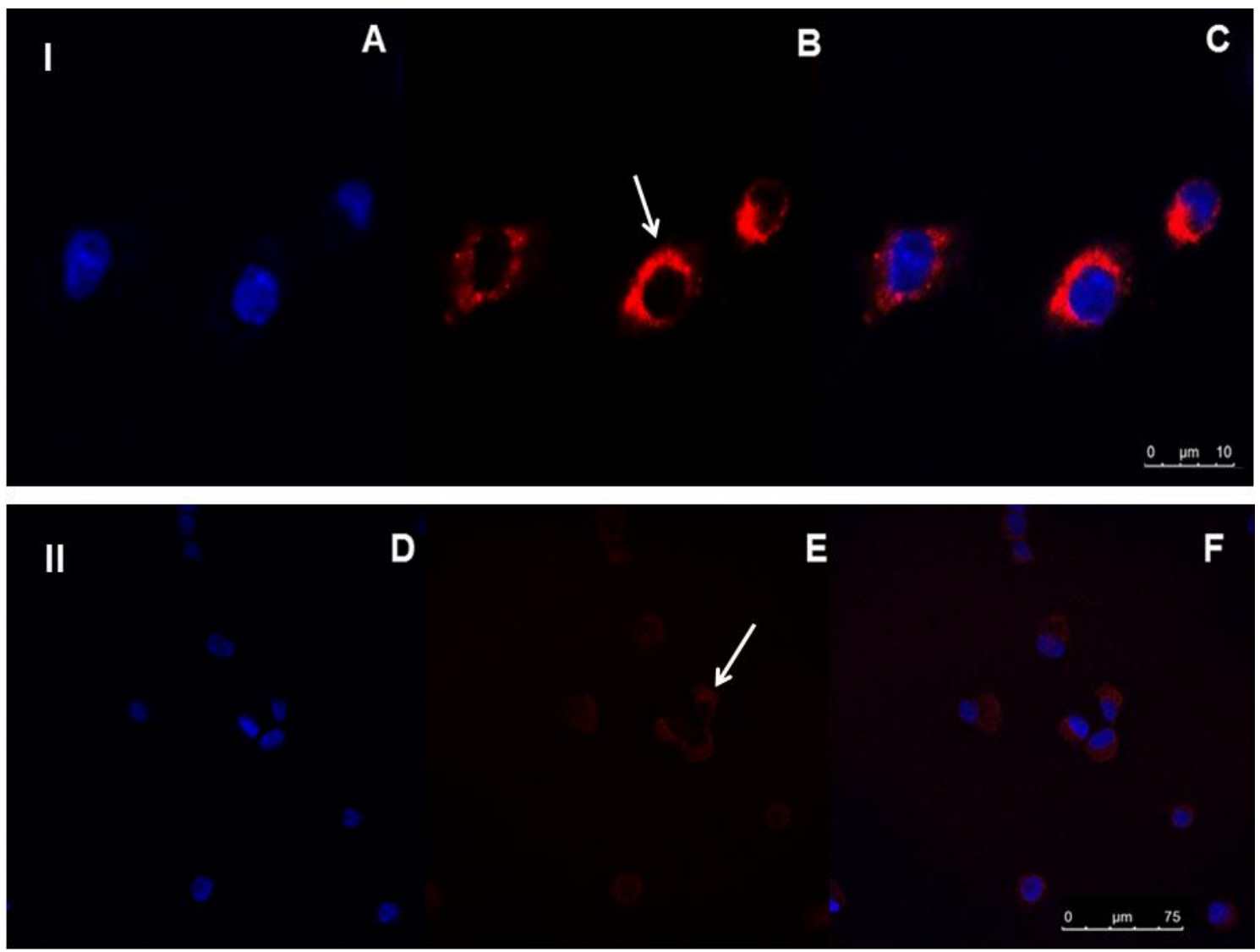

Figura 12. Fotomicrografia confocal de células da linhagem MCF-7 (I)e A431(II), 15 minutos após serem submetidas à $A I C I F t$ livre (I) ou $\mathrm{Fe}_{2} \mathrm{O}_{3} / \mathrm{AO} / \mathrm{P}-\mathrm{F} 127-\mathrm{AICIFt}$ (II) na concentração de $0,09 \mu \mathrm{g} / \mathrm{mL}$. (A e D) coloração azul mostra o núcleo das células corado com DAPI; ( $\mathrm{B}$ e E) coloração vermelha é o resultado da florescência da AICIFt livre e adsorvida à $\mathrm{Fe}_{2} \mathrm{O}_{3} / \mathrm{AO} / \mathrm{P}-\mathrm{F} 127$, respectivamente, no citoplasma (setas); (C) sobreposição das imagens $A-B ;(F)$ sobreposição das imagens $D-E$.

O perfil de morte celular induzido pela terapia fotodinâmica mediada por AICIFt adsorvida a NOP foi determinado por meio do ensaio de AnexinaV/FITC. Osresultados estãomostrados na Figura 13 e expressos na Figura 14.

A Figura 13 ilustra os histogramas, obtidos por meio de citometria de fluxo,demostrando células que incorporaram ou não o iodeto de propidio e/oua Anexina-V-FITC, sendo que no Quadrante 4 (Q4) - quadrante inferior esquerdo 
- estão as células que não incorporaram nem o iodeto de propídio nem a Anexina-V-FITC, ou seja, células viáveis. Nos Q1 (quadrante superior esquerdo) e Q2 (quadrante superior direito) estão as células que incorporaram o iodeto de propídio, mas não incorporaram a Anexina-V-FITC, células em necrose. Já o Q3(quadrante inferior direito) refere-se às células que incorporaram a Anexina-V-FITC, mas não incorporaram o iodeto de propídio, ou seja, células em apoptose.

(A)

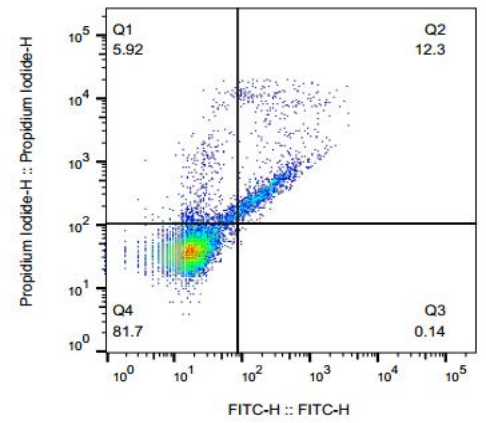

(B)

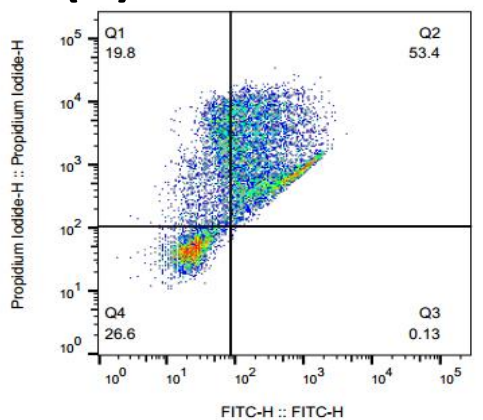

(C)

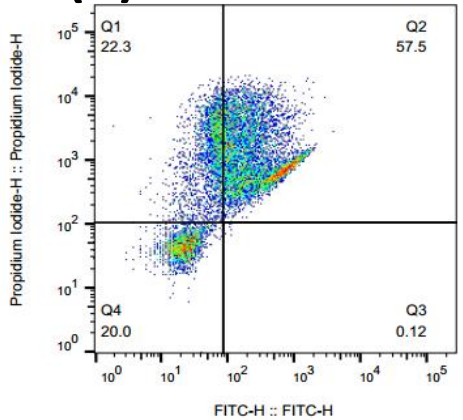

Figura 13: Histogramas representativosobtidos em citômetro de fluxo de células da linhagem A431 coradas com Anexina-V-FITC e lodeto de propídio. (A) Células controle (B) células tratadas com $\mathrm{Fe}_{2} \mathrm{O}_{3} / \mathrm{AO} / \mathrm{P}-\mathrm{F} 127-\mathrm{AlCIFt}$, cuja concentração de AICIFt é $0,04 \mu \mathrm{g} / \mathrm{mL}$ e irradiadas com Luz LEDcom densidade de energia de $23,70 \mathrm{~J} / \mathrm{cm}^{2} ;(\mathrm{C})$ células tratadas com $\mathrm{Fe}_{2} \mathrm{O}_{3} / \mathrm{AO} / \mathrm{P}-\mathrm{F} 127-\mathrm{AlClFt}$, cuja concentração de AICIFt é $0,09 \mu \mathrm{g} / \mathrm{mL}$, e irradiadas com Luz LED com densidade de energia de $23,70 \mathrm{~J} / \mathrm{cm}^{2}$.

A partir de histogramas como os ilustrados na Figura 13,obtidos para cada linhagem celular, quantificaram-se os dados, que estão apresentados na Figura 14.Nessa Figuraobserva-se que a morte celular induzida NOP-AICIFt após irradiação foi ocasionada,principalmente por necrose, pois dentre as células mortas, a frequência de células em necrose foi de $97,22 \%, 100 \%$ 44,31\% e 64,03\%, para as linhagens NIH-3T3; MCF-7, A431 e HeLa, respectivamente, quando a terapia fotodinâmica foi mediada pela NOP-AICIFt na concentração de $0,04 \mu \mathrm{g} / \mathrm{mL}$. A morte celular induzida pela terapia fotodinâmica mediada pela NOP-AICIFt na concentração de $0,09 \mu \mathrm{g} / \mathrm{mL}$ também 
foi predominantemente ocasiona por necrose;dentre as células mortas, a frequência de células em necrose foi superior a $90,00 \%$.

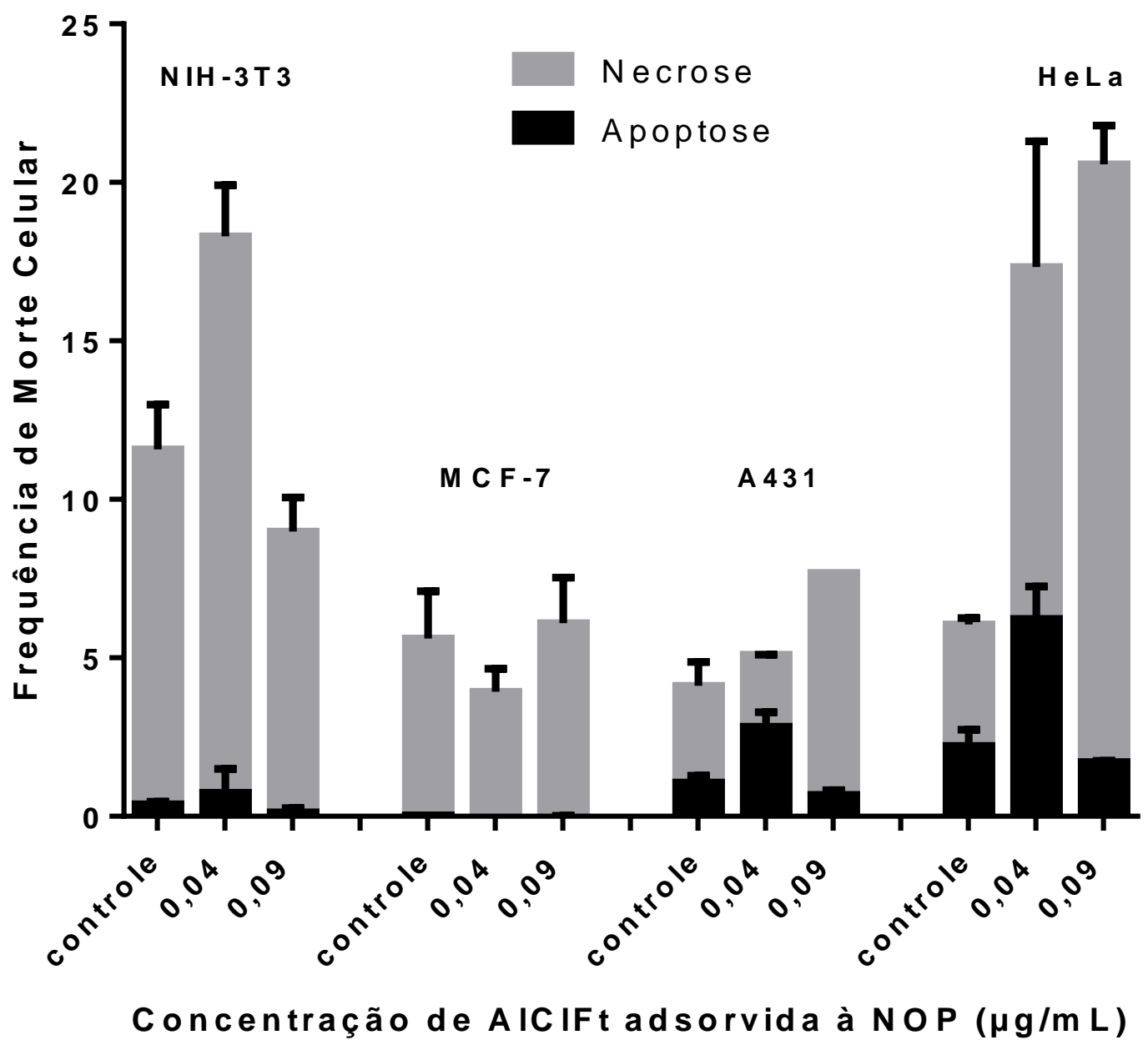

Figura 14. Ensaio de Anexina-V/FITC. Frequência de morte celular por necrose (cinza) e apoptose (preto) em células da NIH-3T3, MCF-7, A431 e HeLa submetidas à terapia fotodinâmica, mediada por $\mathrm{Fe}_{2} \mathrm{O}_{3} / \mathrm{AO} / \mathrm{P}-\mathrm{F} 127-\mathrm{AICIFtcom}$ concentrações de AICIFt iguais a $0,04 \mu \mathrm{g} / \mathrm{mL}$ e $0,09 \mu \mathrm{g} / \mathrm{mLe}$ irradiadas com densidade de energia igual a $23,70 \mathrm{~J} / \mathrm{cm}^{2}$.Dados estão representados como média \pm EPM para duplicata.

Para validar os resultados obtidos no ensaio de Anexina-V/FITC, avaliou-se o potencial elétrico de membranas mitocondriais. Os resultados estãodemonstrados na Figura 15 e expressos na Figura 16. 
$\mathrm{Na}$ Figura 15são mostradosos histogramasrepresentativos desse potencial elétrico obtido por meio de citometria de fluxo. Nele as áreas em cinza indicam células cujas mitocôndrias não apresentam alteração no potencial elétrico, à direita dele encontram-se as células com alteração no potencial elétrico, com membranas mitocondriais despolarizadas, e à esquerda do pico situam-se células também com alteração no potencial elétrico, mas hiperpolarizadas.

(A)

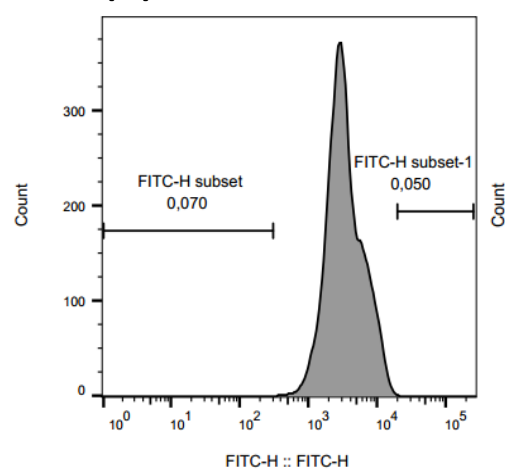

(B)

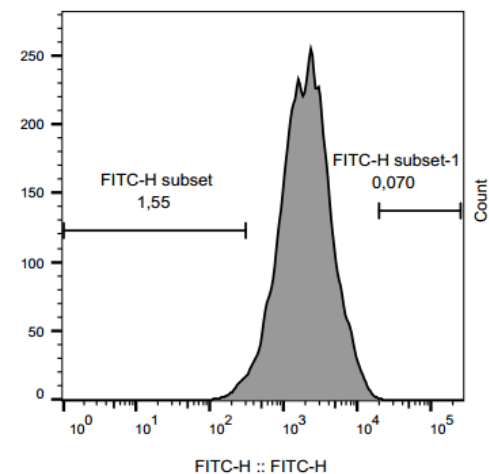

(C)

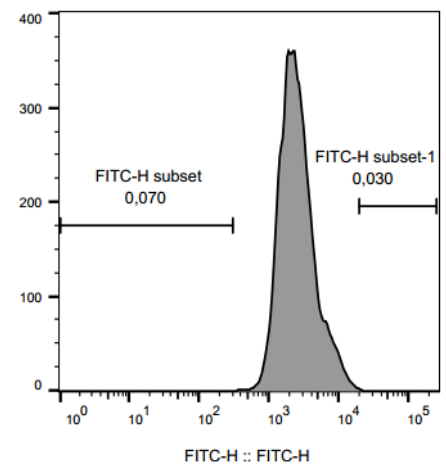

Figura 15. Histogramas representativos do potencial elétrico de membranas mitocondriais de células da linhagem MCF-7 coradas com Rodamina-123. (A) células controle (B) células submetidas à terapia fotodinamica mediada $\mathrm{Fe}_{2} \mathrm{O}_{3} / \mathrm{AO} / \mathrm{P}-\mathrm{F} 127-\mathrm{AlClFt}$, cuja concentração de AICIFt é 0,04 $\mu \mathrm{g} / \mathrm{mLe}$ irradiadas com Luz LEDcom densidades de energia de 23,70J/cm²; (C) células tratadas com $\mathrm{Fe}_{2} \mathrm{O}_{3} / \mathrm{AO} / \mathrm{P}-\mathrm{F} 127-\mathrm{AlCIFt}$, cuja concentração de AlCIFt é $0,09 \mu \mathrm{g} / \mathrm{mL}$ e irradiadas com Luz LEDcomdensidades de energia de $23,70 \mathrm{~J} / \mathrm{cm}^{2}$.

A partir de histogramas, como os ilustrados na Figura 15, obtidos para cada linhagem celular, quantificaram-se os dados que estão apresentados na Figura 16. Nela observa-se que somente as mitocôndrias das células da linhagem NIH-3T3 apresentam alteração no potencial elétrico, mais especificamente despolarização. 


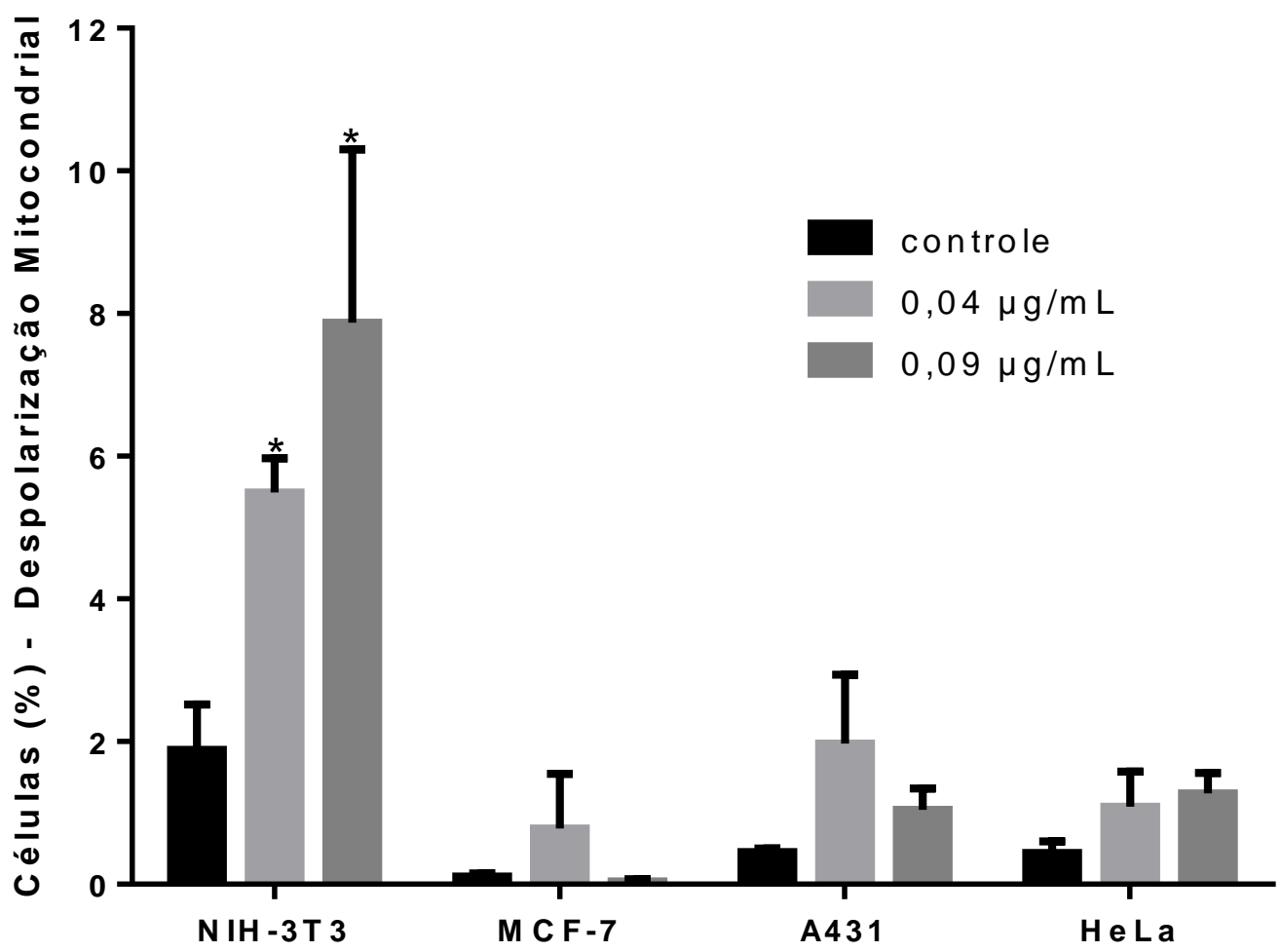

Figura 16. Frequência de células NIH-3T3, MCF-7, A431 e HeLa com despolarização de membranas mitocondriais após serem submetidas à terapia fotodinâmica mediada pelaAICIFt adsorvida $\mathrm{aFe}_{2} \mathrm{O}_{3} / \mathrm{AO} / \mathrm{P}-\mathrm{F} 127$, nas concentrações de $0,04 \mu \mathrm{g} / \mathrm{mL}$ e $0,09 \mu \mathrm{g} / \mathrm{mL}$ e irradiadas com densidade de energia igual a $23,70 \mathrm{~J} / \mathrm{cm}^{2}$. Dados estão representados como média \pm EPM para duplicata. Simbolos $\left({ }^{*}\right)$ denotam diferenças significativas dentro da mesma linhagem em relação ao controle.

A Figura 17 ilustra a frequência de fragmentação doDNA induzida pela terapia fotodinâmica, mediada pela AICIFt adsorvida a $\mathrm{Fe}_{2} \mathrm{O}_{3} / \mathrm{AO} / \mathrm{P}-\mathrm{F} 127$, sobre ascélulas das linhagens NIH-3T3, MCF-7 A431 e HeLa. Nela pode-se observar que entre as células não tratadas (grupo controle) as células da linhagem A431 são as que mostraram maior quantidade de DNA fragmentado, quase $20 \%$. Nessa mesma figura observa-seque a terapia fotodinâmicaaumentou a fragmentação do DNA das células das quatro linhagens. Nas linhagens NIH3T3 e A431 essa fragmentação foi, respectivamente, 38,06\% e 37,60\% quando a terapia fotodinâmica foi mediada com AICIFt na concentração de $0,04 \mu \mathrm{g} / \mathrm{mL}$. 
Já quando a terapia fotodinâmicafoi mediada pela AICIFt na concentração de $0,09 . \mu \mathrm{g} / \mathrm{mL}$, a fragmentação do DNA aumentou nas células NIH-3T3 (67,78\%), MCF-7 (19,20\%), A431 (47,95\%) quando comparado aos respectivos controles.

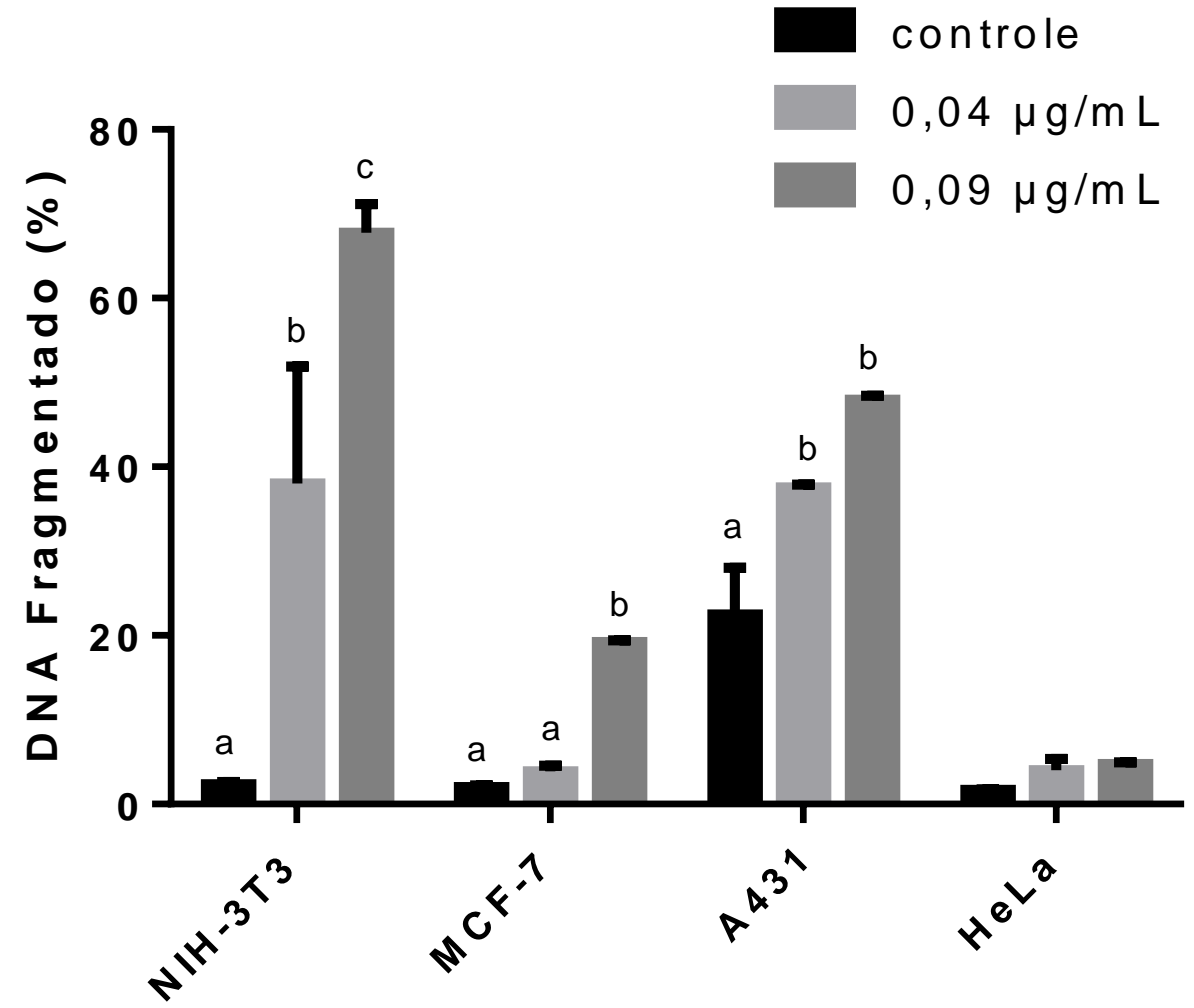

Linhagens celulares

Figura 17. Frequência de fragmentação do DNA em células NIH-3T3, MCF-7, A431 e HeLa submetidas a terapia fotodinâmica, mediada por AICIFt adsorvida a $\mathrm{Fe}_{2} \mathrm{O}_{3} / \mathrm{AO} / \mathrm{P}-\mathrm{F} 127$, nas concentrações de $0,04 \mu \mathrm{g} / \mathrm{mL}$ e $0,09 \mu \mathrm{g} / \mathrm{mL}$ e irradiadas com densidade de energia igual a $23,70 \mathrm{~J} / \mathrm{cm}^{2}$. Dados estão representados como média \pm EPM para duplicata. Letras distintas denotam diferenças significativas dentro da mesma linhagem.

A fim de avaliar se as células que sobreviveram àterapia fotodinâmica mantinham a capacidade proliferativa foram realizadas duas sessões de terapia fotodinâmica cujas concentrações de AICIFt adsorvida a NOP eram iguais a $0,02 \mu \mathrm{g} / \mathrm{mL}, 0,04 \mu \mathrm{g} / \mathrm{mL}, 0,09 \mu \mathrm{g} / \mathrm{mL}$. Os resultados estão expressos nas figuras 18 (linhagem NIH-3T3), 19 (linhagem MCF-7), 20 (linhagem A431) e 21 (linhagem HeLa). Nessas figuras pode-se observar que durante o período de 
adaptação, ou seja, durante as vinte e quatro horas que precediam a terapia fotodinâmica, todas as linhagens mostraram proliferação celular.

NaFigura18Apode-se observar queo índice celularda linhagem $\mathrm{NIH}$ 3T3após a terapia fotodinâmica mediada pela AICIFt na concentração igual a $0,02 \mu \mathrm{g} / \mathrm{mLnão}$ difere do índice apresentado pelo grupo controle,tanto depois de48 horas da primeira sessão (seta preta) quanto após 48 horas da segunda sessão deterapia fotodinâmica (seta vermelha).Entretanto, quando a terapia fotodinâmica foi mediada pela AICIFt,cuja concentração era igual a $0,04 \mu \mathrm{g} / \mathrm{mL}$ e $0,09 \mu \mathrm{g} / \mathrm{mL}$ índice celularé significativamente menor do que oapresentado pelo grupo controle após 48 horas da primeira sessão de terapia fotodinâmica(seta preta), sendo que essas células não sobreviveram a segunda sessãode terapia fotodinâmica (seta vermelha).

\section{Linhagem Celular NIH-3T3}

(A)

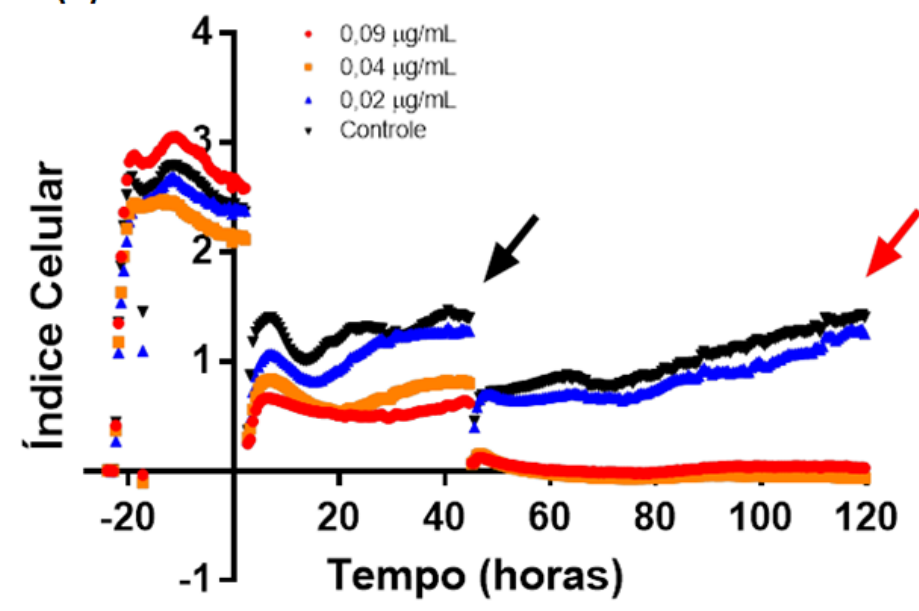

(B)

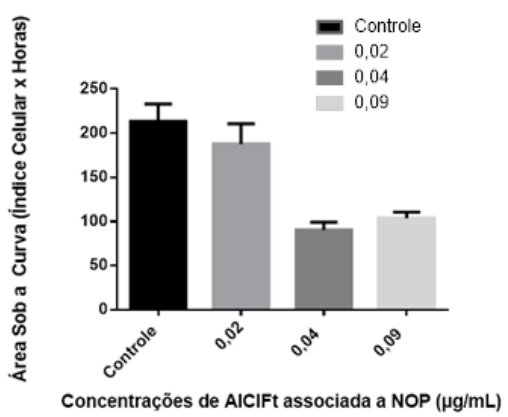

Figura 18:Dinâmica da proliferação celular da linhagem NIH-3T3, antes e após duas sessões de terapia fotodinâmica, mediada por AICIFt adsorvida a $\mathrm{Fe}_{2} \mathrm{O}_{3} / \mathrm{AO} / \mathrm{P}-\mathrm{F} 127$, com diferentes concentrações de AICIFt e irradiadas com luz LED comdensidade de energia igual a $23,70 \mathrm{~J} / \mathrm{cm}^{2}$. (A) Índice celular antes (negativo), após 48 horas da primeira sessão da terapia fotodinâmica (seta preta), 48 horas após a segunda sessão da terapia fotodinâmica (seta vermelha); (B) Área sob a curva do padrão de proliferação das células. 
A linhagemMCF-7(Figura 19A), 48 horas após a primeira sessão de terapia fotodinâmica (seta preta), qualquer que seja a concentração de AICIFt utilizada,apresentaíndicecelular significativamente menor do que o do controle, sendo que quando a terapia fotodinâmica foi mediada com AICIFt na concentração de $0,04 \mu \mathrm{g} / \mathrm{mLe} 0,09 \mu \mathrm{g} / \mathrm{mL}$ as célulasnão sobrevivem à segunda sessão de terapia fotodinâmica (seta vermelha).

\section{Linhagem Celular MCF-7}

(A)

(B)
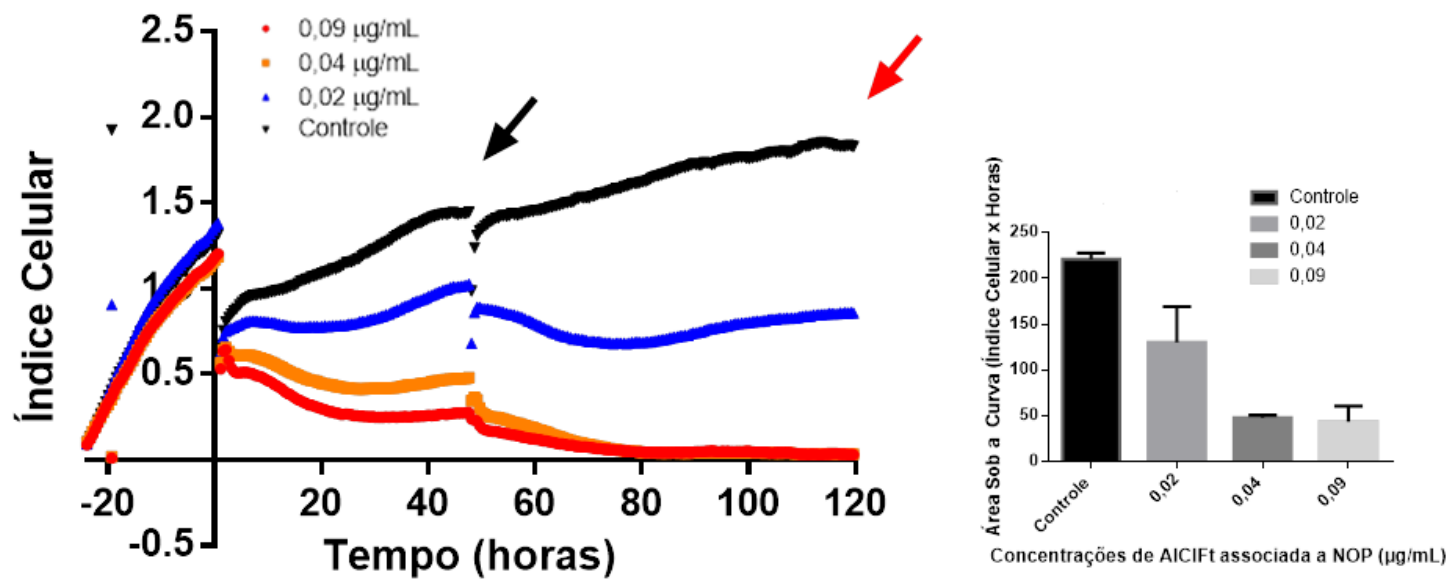

Figura 19:Dinâmica da proliferação celular da linhagem MCF-7, antes e após duas sessões de terapia fotodinâmica, mediada por AICIFt adsorvida a $\mathrm{Fe}_{2} \mathrm{O}_{3} / \mathrm{AO} / \mathrm{P}-\mathrm{F} 127$, com diferentes concentrações de AICIFt e irradiadas com luz LED com densidade de energia igual a $23,70 \mathrm{~J} / \mathrm{cm}^{2}$. (A) Índice celular antes (negativo), após 48 horas da primeira sessão da terapia fotodinâmica (seta preta), 48 horas após a segunda sessão da terapia fotodinâmica (seta vermelha); (B) Área sob a curva do padrão de proliferação das células.

Da mesma forma, a linhagem A431(Figura 20A), 48 horas após a primeira (seta preta), qualquer que seja a concentração de AICIFt utilizada, também apresenta índice celular significativamente menor do que o do controle, sendo que a diferença entre os índices celulares apresentados pelos grupos tratados aumenta após 48 horas da segunda sessão de terapia fotodinâmica (seta vermelha) quando comparado ao grupo controle. 


\section{Linhagem Celular A431}

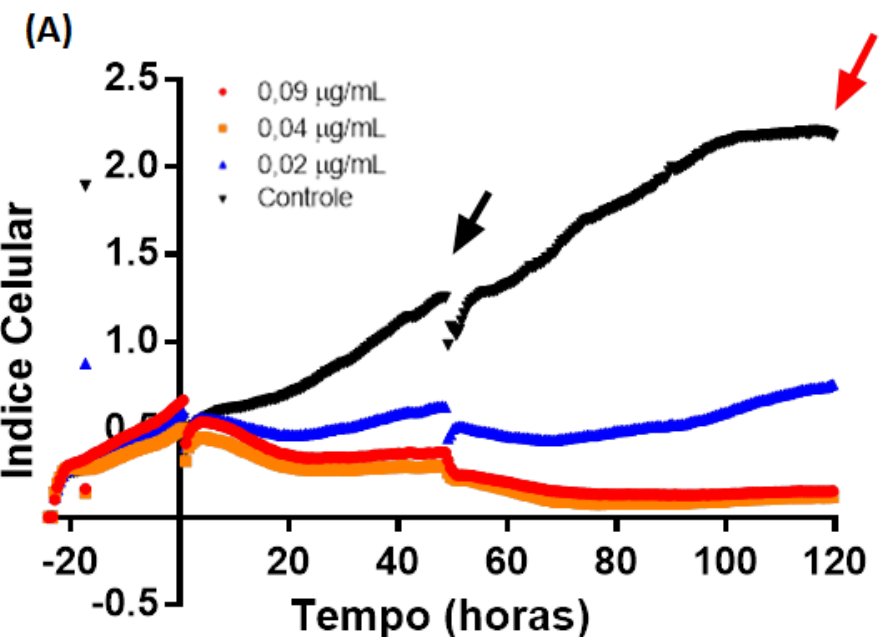

(B)

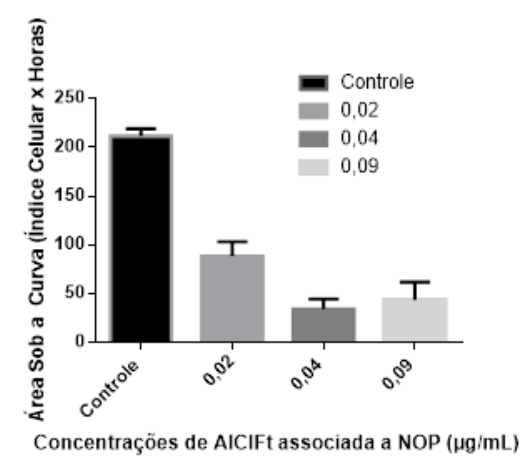

Figura 20:Dinâmica da proliferação celular da linhagem A431, antes e após duas sessões de terapia fotodinâmica, mediada por AICIFt adsorvida a $\mathrm{Fe}_{2} \mathrm{O}_{3} / \mathrm{AO} / \mathrm{P}-\mathrm{F} 127$, com diferentes concentrações de AICIFt e irradiadas com luz LED comdensidade de energia igual a $23,70 \mathrm{~J} / \mathrm{cm}^{2}$. (A) Índice celular antes (negativo), após 48 horas da primeira sessão da terapia fotodinâmica (seta preta), 48 horas após a segunda sessão da terapia fotodinâmica (seta vermelha); (B) Área sob a curva do padrão de proliferação das células.

Com relação à linhagem HeLa, a Figura $21 \mathrm{~A}$ mostra que somente a população de células submetidas à terapia fotodinâmicacom AICIFt na concentração de 0,02 $\mu \mathrm{g} / \mathrm{mL}$ apresenta o índice celular igual ao do controle, 48 horas após a primeira (seta preta). Após a segunda sessão de terapia (seta vermelha), a população de células submetidas à terapia fotodinâmica mediada pela AICIFt na concentração de $0,02 \mu \mathrm{g} / \mathrm{mL}$ e $0,04 \mu \mathrm{g} / \mathrm{mL}$ apresentam o índice celular igual ao do grupo controle, sendo que as células submetidas à terapia fotodinâmica mediada pela AICIFt na concentração de $0,09 \mu \mathrm{g} / \mathrm{mL}$ não sobreviveram.

Os dados relacionados ao índice celular podem também ser observados em 18B,19B, 20B e 21B que mostram a área sob a curva do índice celular dessas linhagensao longo do tempo deste estudo. Nessas figuras observa-se também que ao longo de todo o tempo, o índice celular diminui quando as 
células são submetidas à terapia fotodinâmica mediada pela AICIFt na concentração de $0,04 \mu \mathrm{g} / \mathrm{mL}$ e $0,09 \mu \mathrm{g} / \mathrm{mL}$.

\section{Linhagem Celular HeLa}

(A)

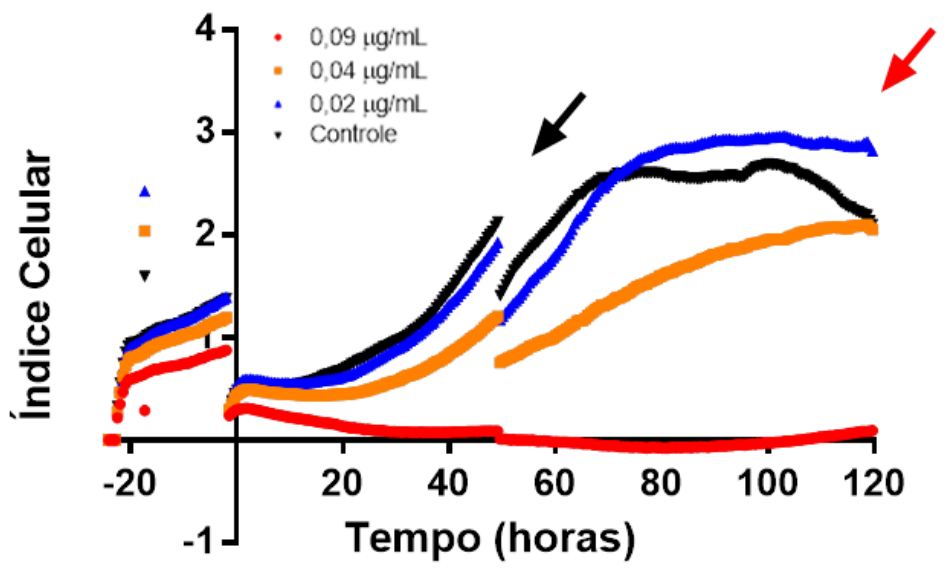

(B)

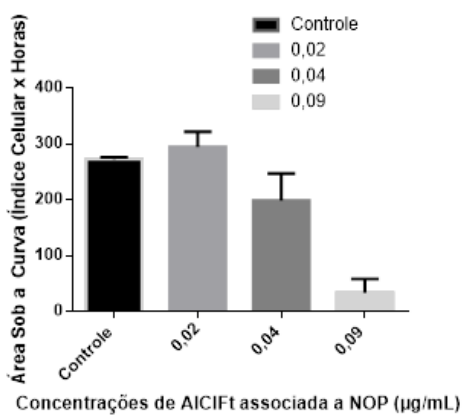

Figura 21:Dinâmica da proliferação celular da linhagem HeLa, antes e após duas sessões de terapia fotodinâmica, mediada por AICIFt adsorvida a $\mathrm{Fe}_{2} \mathrm{O}_{3} / \mathrm{AO} / \mathrm{P}-\mathrm{F} 127$, com diferentes concentrações de AICIFt e irradiadas com luz LED com densidade de energia igual a $23,70 \mathrm{~J} / \mathrm{cm}^{2}$. (A) Índice celular antes (negativo), após 48 horas da primeira sessão da terapia fotodinâmica (seta preta), 48 horas após a segunda sessão da terapia fotodinâmica (seta vermelha); (B) Área sob a curva do padrão de proliferação das células. 
A prevenção e o diagnóstico precoce de qualquer tipo de câncer, associado ao tratamento eficaz, são fundamentais para que os índices de incidência e mortalidade por câncer possam ser reduzidos. De acordo com o INCA, o aumento de sobrevida do paciente com câncer de mama deve-se à redução na mortalidade pós-operatória com tratamento adequado. Ainda segundo esse mesmo Instituto, a maior sobrevida de pacientes com câncer de próstata está relacionada diretamente à maior oferta do exame que detecta os níveis do Antígeno Prostático Específico, PSA, (INCA, acessado em julho de 2015). Entretanto, o tratamento adequado deve envolver terapias efetivas com o mínimo de efeitos adversos.

Uma dessas terapias, que oferece a possibilidade de erradicação do câncer, com efeitos adversos menores nas estruturas sadias do organismo, é a TFD, uma modalidade terapêutica bem estabelecida, descrita como mais seletiva ao tecido tumoral (OLIVEIRA et alli, 2015). Essa maior seletividade da TFD parece estar relacionada ao acúmulo preferencial do fármaco fotossensibilizante no tecido tumoral (BHUVANESWARI et alli, 2009), retenção essa, que ocorre, principalmente, devido à maior permeabilidade dos vasos sanguíneos tumorais associada à menor drenagem linfática no microambiente tumoral (ISSA \& MANELA-AZULAY, 2010). Além disso, há de se considerar o fato de que o maior problema após a remoção cirúrgica da massa tumoral é a persistência de células neoplásicas à margem da cirurgia, daí a importância da TFD que é capaz de erradicar seletivamente tais células (ANG et alli, 2014). Inclusive em tumores cerebrais, Vanaclocha e colaboradores (2015) mostraram que a TFD foi capaz de eliminar células neoplásicas da margem cirúrgica, 
podendo, segundo esses autores, ser considerada como um adjuvante da cirurgia e/ou radioterapia e quimioterapia no tratamento de tumores cerebrais.

Atualmente, a tendência das pesquisas em TFD, consiste principalmente no desenvolvimento de fotossensibilizantes aprimorados, ou seja, que permitam maior efetividade do tratamento. Dentre esses fotossensibilizantes testados atualmente estão os de terceira geração, sendo os mais promissores aqueles que são constituídos de ftalocianinas.

As ftalocianinas apresentam grande lipofilicidade e por isso tendem a localizar-se nas membranas celulares, localização ideal para a ação fotodinâmica, além de apresentarem alto coeficiente de absorção na faixa de 650 a $850 \mathrm{~nm}$ em energias em torno de $100 \mathrm{~J} / \mathrm{cm}^{2}$. De acordo com Nunes e colaboradores (2004), as ftalocianinas apresentam as propriedades fotofísicas mais favoráveis para a aplicação na TFD quando são complexadas com íons metálicos, tais como zinco, alumínio ou cloro.

No entanto, as ftalocianinas são moléculas hidrofóbicas, o que, embora facilite a sua passagem através das membranas celulares, dificulta o seu uso por via endovenosa, que necessita de meio fisiológico. Por isso elas precisam ser incorporadas em um sistema de liberação de fármacos adequado para que in vivo possam ser administradas endovenosamente (BATRAKOVA et alli, 2008; LE et alli, 2013), constituindo assim os fotossensibilizantes de terceira geração. Vale ressaltar que um sistema de liberação de fármacos adequado é aquele que não só aumenta a solubilidade do fármaco incorporado, mas também a sua estabilidade metabólica e o seu tempo de circulação no organismo (BATRAKOVA et alli, 2008). Nesse sentido, as nanopartículas que podem contornar o sistema mononuclear fagocitário e os outros mecanismos 
de defesa, são as mais promissoras. Dentre elas destacam-se as nanopartículas poliméricas, que não só funcionam como transportadores de fármacos, mas também interferem em funções das células. Um exemplo promissor de tais nanomateriais é a classe dos Pluronics $\AA$, um tipo de copolímero em bloco.

Os Pluronics são capazes de interagir com membranas biológicas, sendo assim translocados para o interior das células onde alteram a respiração mitocondrial, a transdução de sinal para o processo apoptótico, entre outros. No contexto do câncer, eles são interessantes, pois inibem a atividade de proteínas expressas na superfície celular que funcionam como transportadores de efluxo de drogas, em particular a Glicoproteína-P (BATRAKOVA et alli, 2008). Um copolímero dessa classe bastante utilizado como sistema de liberação de fármacos é o Pluronic F-127, pois apresenta baixa toxicidade. Ele é composto por seções alternadas de poli(óxido de etileno)-poli(óxido de propileno) (PPO)-poli(óxido de etileno) (PEO), sendo que o segmento PPO é relativamente hidrofóbico comparado aos segmentos de PEO próximos. Devido a essa diferença de hidrofobicidade, o Pluronic F127 em meio aquoso rapidamente configura-se em micelas, o que permite a incorporação de drogas hidrofílicas e hidrofóbicas e o prolongamento da liberação dessas (LE et alli, 2013).

Além de nanopartículas poliméricas, nanopartículas magnéticas também constituem sistemas carreadores de drogas eficazes, uma vez que elas podem ser atraídas para um local especifico por meio de um campo magnético externo. Assim drogas carreadas na circulação sanguínea por nanopartículas 
magnéticas podem ser atraídas para o tumor e como citado anteriormente, uma vez no tumor podem ser utilizadas para induzir hipertermia.

Por isso, o encapsulamento simultâneo de fármacos fotossensibilizantes com nanopartículas magnéticas tem sido reconhecido como uma alternativa promissora para o tratamento do câncer por possibilitar o efeito sinergístico da magnetohipertermia e da TFD, uma vez que já foi demonstrado que nanopartículas de $\mathrm{Fe}_{3} \mathrm{O}_{4}$ podem ser aquecidas com luz LED. Chu e colaboradores (2013) mostraram diminuição da viabilidade de células tumorais, tanto in vitro, quanto in vivo, após induzir aumento de temperatura local quando irradiaram nanopartículas magnéticas $\left(\mathrm{Fe}_{3} \mathrm{O}_{4}\right)$ com luz LED em comprimento de $808 \mathrm{~nm}$.

Diante disso, pesquisadores do INCT - Nanobiotecnologia desenvolveram um nanossistema, $\mathrm{Fe}_{2} \mathrm{O}_{3} / \mathrm{AO} / \mathrm{P}-\mathrm{F} 127-\mathrm{AlClFt}$, que pudesse ser utilizado na TFD associada à magnetohipertermia, simultaneamente ou não. Neste estudo, entretanto, analisou-se somente a eficácia desse sistema denominado, NOP-AICIFt, na TFD, e não na magnetohipertermia.

A primeira etapa deste estudo consistiu na escolha das linhagens celulares que constituiriam os modelos nos quais seria aplicada a TFD e para isso, considerou-se o fato de que o câncer é um tecido complexo, no qual células tumorais, com alterações genéticas diferentes, interagem com células não tumorais tais como fibroblastos, células do sistema imunitário e células endoteliais, sendo que essas células não tumorais são cooptadas pelas tumorais a funcionar de acordo com a nova dinâmica tecidual. Além disso, é importante salientar que um tratamento com o mínimo de efeitos adversos, envolve a utilização de um fármaco sem ação tóxica e/ou genotóxica sobre as 
células dos tecidos não tumorais do organismo. Assim, a escolha de uma linhagem não tumoral, NIH-3T3, e de diferentes linhagens tumorais, MCF-7, A431 e HeLa, para constituírem o modelo deste estudo mostrou-se interessante, pois essas linhagens não só são provenientes de tecidos diferentes, como também cada uma delas, no caso das linhagens tumorais, é constituída de células com múltiplas alterações genéticas específicas que podem levar a diferentes respostas ao mesmo fármaco.

Uma vez definido os modelos de estudo considerou-se o fato de que a efetividade da TFD é dependente, entre outros, da dose de energia aplicada às células, que embora deva ser suficiente para excitar o fotossensibilizante, na ausência deste não deve ser citotóxica. Assim, realizaram-se ensaios cujos resultados possibilitaram determinar a dose de energia a ser aplicada às células durante a TFD. Como a dose de energia depende da potência da fonte de luz e do tempo de irradiação, diferentes doses de energia foram testadas alterando-se a potência da aplicação da luz LED e o tempo de irradiação.

A análise dos dados mostrou que as linhagens MCF-7 e HeLa não foram afetadas quando as suas células foram irradiadas com densidade de energia de $23,70 \mathrm{~J} / \mathrm{cm}^{2}$, sendo que as linhagens $\mathrm{NIH}-3 \mathrm{~T} 3$ e a A431 apresentaram, respectivamente, redução e aumento da população quando irradiadas com essa mesma dose de energia. Embora a luz LED não libere energia suficiente para causar danos aos tecidos biológicos, com determinadas densidades de energia ela pode estimular ou inibir a proliferação celular. Talvez o aumento da população de células da linhagem A431 aqui observado possa estar relacionado ao fato de que a radiação emitida por um LED pode ativar a citocromo c oxidase, presente nas mitocôndrias das células eucariotas. A 
citocromo c oxidase é uma proteína que transfere elétrons para uma molécula de oxigênio, convertendo assim o oxigênio molecular em duas moléculas de água. Neste processo, dá-se a translocação de quatro prótons, que ajudam a formação de um potencial quimiosmótico que é usado pela ATP sintetase para formar ATP. O aumento de ATP pode levar ao aumento da atividade metabólica e do número de células. Wu e colaboradores (2014) mostraram que fibroblastos humanos da derme quando irradiados com luz LED produzem mais ATP quando comparados aos fibroblastos não irradiados. Entretanto, tem que se considerar que a literatura relata que a irradiação com luz LED aumenta a leitura do MTT e que esse aumento muitas vezes é interpretado como maior proliferação celular, lembrando que o ensaio do MTT mede um conjunto de atividades enzimáticas relacionadas ao metabolismo celular, podendo ser utilizado como um indicador direto da citotoxicidade induzida por drogas. Neste estudo, o ensaio MTT foi utilizado para medir o metabolismo mitocondrial e assim inferir a viabilidade celular.

Já a diminuição da população celular observada na linhagem NIH-3T3 pode ser devido à ativação da via extrínseca de ativação do processo apoptótico, como demonstrado em células HT29, células de câncer de colón, por Matsumoto e colaboradores em 2014. Considerando isso e o fato de que estudos anteriores, desenvolvidos pelo grupo no qual este estudo está inserido, já tinham mostrado que essa dose energia era ideal para ser utilizada nos ensaio de TFD, decidiu-se realizar os ensaios de TFD irradiando as células com densidade de energia de $23,70 \mathrm{~J} / \mathrm{cm}^{2}$.

Mas antes da realização da TFD realizou-se um ensaio para saber se a AICIFt adsorvida a NOP, ao ser irradiada, mantinha a capacidade de induzir a 
produção de ${ }^{1} \mathrm{O}_{2}$, que na TFD é principal molécula citotóxica, pois pode oxidar qualquer biomolécula dentro da célula, o que segundo Carré e colaboradores (1999) torna mais difícil para as células desenvolverem resistência. A análise dos resultados mostrou que, após a irradiação da $\mathrm{Fe}_{2} \mathrm{O}_{3} / \mathrm{AO} / \mathrm{P}-\mathrm{F} 127-\mathrm{AlClFt}$, ocorre decaimento exponencial da absorbância do Benzofurano ao longo do tempo, consistente com a formação de ${ }^{1} \mathrm{O}_{2}$. Isso indica que a AICIFt mesmo quando adsorvida a NOP é capaz de induzir a produção de ${ }^{1} \mathrm{O}_{2}$ quando ativada por luz LED com comprimento de onda de $660 \mathrm{~nm}$. A análise dos resultados mostra também que a produção de ${ }^{1} \mathrm{O}_{2}$ é maior quando a AICIFt está adsorvida a NOP do que quando ela está livre. Segundo Muehlmann e colaboradores (2015), este fato pode ser explicado pelo efeito de extinção; ou seja, como a AICIFt é bastante hidrofóbica, as suas moléculas tendem a agregar-se, o que encurta a distância entre as moléculas. Assim, quando as moléculas de AICIFt livre são irradiadas elas liberam fótons que são captados pelas moléculas mais próximas, no caso outras moléculas de AICIFt e não pelo oxigênio molecular, levando a menor geração de ${ }^{1} \mathrm{O}_{2}$, como observado neste estudo.

A etapa seguinte deste estudo consistiu em avaliar se a AICIFt quando adsorvida a NOP era eficaz como fotossensibilizante a ser utilizado na TFD. Para tal, células foram cultivadas na presença da $\mathrm{Fe}_{2} \mathrm{O}_{3} / \mathrm{AO} / \mathrm{P}-\mathrm{F} 127-\mathrm{AICIFt}$, com concentrações de AICIFt que variaram de $0,000326 \mu \mathrm{g} / \mathrm{mL}$ a $1,5 \mu \mathrm{g} / \mathrm{mL}$ e depois irradiadas, ou não. Com base no teste de atividade mitocondrial, ensaio do MTT, observou-se que as células das diferentes linhagens, tumorais ou não, apresentam respostas diferentes quando expostas a NOP-AICIFt.

Na ausência de irradiação, a NOP-AICIFt induz diminuição ou aumento da viabilidade celular nas linhagens NIH-3T3, MCF-7 e A431, enquanto que 
para as células HeLa ela se mostrou inócua (colunas pretas nos gráficos 6, 7, 8 e 9). Esses resultados podem estar relacionados, não com a AlCIFt, que em outro estudo (MUEHLMANN et alli, 2015) já se mostrou inócua na ausência de irradiação, mas com o ferro existente na NOP, que no meio intercelular participa de diversas atividades. Ele tem influência na progressão celular, uma vez que a enzima que catalisa a formação de desoxirribonucleotídeos necessários para síntese do DNA, a ribonucleotídeo redutase, é dependente de ferro (COTRUVO e STUBBE, 2011); na ausência de ferro o ciclo celular não passa da fase G1 para a fase S (POURCELOT et alli, 2015). Por outro lado, uma vez no citoplasma, o ferro livre pode ser dissociado na forma de íon, o que o torna apto para participar de reações de óxido-redução e, consequentemente, da geração de radicais livres (IMAM et alli, 2015). Recentemente, Imam e colaboradores (2015) demostraram que nanopartículas de oxido de ferro induzem estresse oxidativo, que leva à diminuição da viabilidade de células neuronais. De acordo com Pourcelot e colaboradores (2015), em concentrações nanomolares, o ferro no citoplasma promove proliferação celular, enquanto que em concentrações micromolares ele pode ser tóxico para as células. Ressalta-se que neste estudo não se quantificou o ferro intracelular.

Entretanto, quando as células foram irradiadas, ou seja, quando submetidas à TFD, em todas as linhagens estudadas ocorreu redução da viabilidade celular. Dependendo da linhagem, a redução variava de acordo com a concentração de AICIFt adsorvida à NOP, o que refletiu em grandes variações nos valores de $\mathrm{CL}_{50}$; entre as diferentes linhagens. A linhagem MCF7 foi a mais resistente à TFD, pois apresentou $\mathrm{CL}_{50}$ igual a $2,474 \mu \mathrm{g} / \mathrm{mL}$, enquanto que a linhagem mais sensível à TFD foi a NIH-3T3, linhagem não 
tumoral, cujo CL50 é igual a $0,0108 \mu \mathrm{g} / \mathrm{mL}$. Um fator importante a salientar é que dentre as células vivas detectadas nos diferentes ensaios realizados após a TFD, podem existir algumas que não existiam quando se efetuou a terapia, elas poderiam ser resultado de divisão celular das células que sobreviveram ao tratamento, se assim for é plausível acreditar que a quantidade de células mortas pela TFD poderia ser maior do que a observada nos ensaios de MTT.

Respostas diferentes apresentadas por distintas linhagens celulares quando expostas ao mesmo fármaco já foram descritas em outros estudos (MUEHLMANN et alli. 2014; 2015). Elas podem estar relacionadas à localização intracelular do AICIFt, pois, de acordo com Agostinis e colaboradores (2011), como a vida útil de oxigênio singleto é muito curta, a sua difusão dentro da célula é de no máximo 10-55 nm e, desse modo, os danos induzidos pela TFD afetariam somente as organelas onde se localiza 0 fotossensibilizante ou dependeriam da quantidade do fotossensibilizante incorporado pelas células.

Assim a etapa seguinte deste estudo consistiu em determinar, por meio do método de cromatografia líquida de alta eficiência, a quantidade de AICIFt incorporada pelas células. Para tal, considerou-se o fato de que quando se efetuou a TFD utilizando a AICIFt em concentrações menores do que 0,02 $\mu \mathrm{g} / \mathrm{mL}$ a porcentagem de células não viáveis não diferiu, qualquer que tenha sido a concentração de $\mathrm{AICIFt,} \mathrm{e,} \mathrm{da} \mathrm{mesma} \mathrm{forma} \mathrm{quando} \mathrm{as} \mathrm{concentrações}$ AlCIFt eram superiores a $0,09 \mu \mathrm{g} / \mathrm{mL}$, a citotoxicidade induzida pela TFD não aumentou. Assim, nesta etapa utilizou-se somente NOP cujas concentrações de AlCIFt adsorvida eram iguais a $0,02 \mu \mathrm{g} / \mathrm{mL}, 0,04 \mu \mathrm{g} / \mathrm{mL}, 0,09 \mu \mathrm{g} / \mathrm{mL}$. A análise dos resultados mostra que, depois de quinze minutos de ser adicionada 
ao meio de cultura, a AICIFt é incorporada tanto por células tumorais como por não tumorais, sendo que os níveis de incorporação são similares entre as diferentes linhagens. Em 2014, Muehlmann e colaboradores demonstraram que células tumorais de diversas linhagens incorporam mais a AICIFt do que a linhagem não tumoral NIH-3T3. Vale lembrar que no estudo desses autores a AICIFt estava associada a nanopartículas de poli (vinil-anidrido éter maleico de co-metilo) e não a nanopartículas magnéticas, como neste estudo. Um dado importante a ser destacado é que nenhuma das linhagens incorporou mais do que $1 \%$ da AICIFt adicionada, e isso talvez explique o fato de que 24 horas após a TFD com a maior concentração de AICIFt utilizada $(1,5 \mu \mathrm{g} / \mathrm{mL})$, ainda foram detectadas de 20 a $30 \%$ de células viáveis nas diferentes linhagens. Para se conseguir maior incorporação da AICIFt talvez seja necessário maior tempo, que neste estudo foi de 15 minutos. Muehlmann e colaboradores (2014) mostraram que o pico de incorporação de AICIFt por células tumorais e não tumorais ocorre aos 60 minutos. Por outro lado, há que se considerar que, apesar de as ftalocianinas serem lipofílicas, e substâncias lipofílicas não carreadas poderem atravessar a membrana por difusão simples, neste estudo a AICIFt estava associada a um carreador, NOP, cujo diâmetro hidrodinâmico estava em torno de $280,40 \mathrm{~nm}$, tamanho que talvez tenha dificultado a passagem pela membrana plasmática.

Mas como a eficiência da TFD não depende somente da quantidade do fotossensibilizante incorporado pelas células, mas também de como ele se distribui intracelularmente, decidiu-se verificar a localização intracelular da AICIFt. Por meio de microscopia confocal observou-se que a AICIFt, uma vez dentro da célula, se localiza toda ela no citoplasma. A possibilidade de a AICIFt 
estar localizada na parte externa da membrana citoplasmática foi descartada, pois em todos os experimentos as células eram lavadas com tampão PBS, o que elimina a AICIFt existente sob a célula, sendo assim, os resultados apresentados referem-se à AICIFt internalizada. Já foi demostrado na literatura que os fotossensibilizantes, independente do nanocarreador, se distribuem no citoplasma da célula e não no núcleo e também que a organela em que ele se localizará depende da via pela qual ele entra na célula (ROSENKRANZ et alli, 2000). Alguns deles se localizam em várias organelas, mas a maioria tem como alvo apenas uma. A clorina, por exemplo, acumula, preferencialmente, nos lisossomos; já as ftalocianinas, embora apresentem um largo espectro de afinidade, tem como alvo principal as mitocôndrias. Normalmente, quando o fotossensibilizante está localizado nas mitocôndrias ou no retículo endoplasmático, a TFD induz as células à apoptose. Já quando o fotossensibilizante está localizado na membrana plasmática ou nos lisossomos, o processo apoptótico pode atrasar ou até mesmo ser bloqueado, predispondo as células à necrose (BUYTAERT et alli, 2007).

Esses dois tipos de morte celular diferem quanto ao padrão de alterações bioquímicas e morfológicas que ocorrem na célula. $O$ processo apoptótico é controlado por meio da ativação de enzimas denominadas caspases. Essas enzimas clivam proteínas nucleares e do citoesqueleto, além de ativarem enzimas que degradam o DNA nuclear e as proteínas citoplasmáticas. Isso leva a alterações na assimetria de fosfolipídios de membrana plasmática, levando à formação de vacúolos citoplasmáticos, encolhimento e diminuição do contato entre células vizinhas. Por outro lado, a morte celular por necrose ocorre devido à desnaturação das proteínas 
intracelulares e da digestão enzimática da célula, por enzimas lisossômicas. A incapacidade das células em manter a integridade das membranas leva à ruptura da membrana plasmática e consequentemente à liberação do conteúdo extracelular (KUMAR et alli, 2005).

Além da localização intracelular, a apoptose e a necrose podem ocorrer em resposta ao tratamento com diversos estímulos nocivos, geralmente de uma forma dependente da dose. Muitas substâncias induzem as células à apoptose em doses baixas e à necrose em doses elevadas (RYTER et alli, 2007). No caso da TFD, a dose que determina morte por apoptose ou necrose é, principalmente, influenciada pela dose de energia aplicada para ativar 0 fotossensibilizante (RYTER et alli, 2007).

Assim, a próxima etapa deste estudo consistiu em avaliar, por meio do ensaio de Anexina-V/FITC, em citômetro de fluxo, o mecanismo de morte celular induzido pela TFD. A análise dos dados mostrou que, em quase todas as linhagens estudadas, independente da concentração de AICIFt, a TFD induziu morte celular por necrose. O que no contexto do câncer é um dado importante, pois in vivo, a maioria das células necróticas e seus fragmentos são fagocitados por leucócitos, o que evidencia ativação do sistema imunitário e recrutamento de células desse sistema para a região do tumor.

De modo a validar os resultados obtidos no ensaio de Anexina-V/FITC, avaliou-se, também em citômetro de fluxo, o potencial elétrico de membranas mitocondriais, pois alterações na permeabilidade das mitocôndrias podem por mecanismos diferentes conduzir à morte celular por apoptose ou necrose. Os resultados ilustrados na Figura 16 mostram que somente as mitocôndrias das 
células da linhagem NIH-3T3 apresentam alteração no potencial elétrico, mais especificamente despolarização.

Muito provavelmente a necrose observada nas células da linhagem NIH3T3 começou nas mitocôndrias, pois com a despolarização da membrana mitocondrial há influxo maciço de cálcio nas mitocôndrias, lesionando-as de maneira permanente, levando à inibição das enzimas celulares, desnaturação de proteínas e causando as alterações celulares típicas de necrose. Já nas outras linhagens, a necrose pode ter começado em outras organelas. Pois, a perda da integridade da membrana celular e a lise de lisossomos podem também levar as células à necrose. Além disso, como citado anteriormente, quando a ftalocianina está localizada nas mitocôndrias ou no retículo endoplasmático, a TFD induz as células à apoptose, já quando ela está localizada na membrana plasmática ou nos lisossomos a TFD induz as células à necrose. Ressalta-se que os padrões específicos de localização intracelular de um fotossensibilizante podem variar entre diferentes tipos de células.

Como nos ensaios de MTT o melhor resultado obtido foi o observado nos grupos submetidos à TFD com NOP-AICIFt que continha concentrações de AICIFt igual a 1,5 $\mu \mathrm{g} / \mathrm{mL}$, a maior concentração utilizada, nesses grupos ainda existiam cerca de $20 \%$ de células vivas, decidiu-se avaliar se as células visualizadas no ensaio de Anexina-V/FITC em degeneração, e as que sobreviveram à TFD tinham danos no DNA, pois já é bem conhecido que morte celular pode também ser desencadeada em resposta a danos no DNA. Na análise dos resultados constatou-se que as células das linhagens A431 são as mais instáveis geneticamente, pois mesmo na ausência de tratamento 
mostraram quase $20 \%$ do DNA fragmentado, enquanto que nas outras linhagens a taxa de DNA fragmentado não passou dos $2 \%$.

Após a TFD somente as células da linhagem HeLa é que não apresentaram aumento da fragmentação do DNA. Os danos no DNA podem envolver as bases nitrogenadas e o açúcar, além de ligações cruzadas entre o DNA e proteínas. Esses danos podem fazer com que ocorram quebras na molécula de DNA. Quando isso acontece, a reação inicial das células é a de ativar o sistema de reparo, porém nem sempre a célula consegue reparar todos os danos, e, nesse caso, ela pode entrar em degeneração ou, em caso de danos não letais, transmitir o dano para as células descendentes. Mesmo que isto ocorra, pode não haver consequências importantes para a célula; no entanto, em alguns casos, danos ao DNA provocam uma alteração genética que pode conferir à célula algum tipo de vantagem como, por exemplo, vantagem proliferativa, o que no contexto do câncer é muito perigoso. Com a metodologia utilizada neste estudo é difícil afirmar se a fragmentação do DNA observada é consequência da morte celular ou se ela está ocorrendo nas células sobreviventes à TFD. Independentemente disso, o ideal é que a TFD seja capaz de eliminar a maioria das células neoplásicas e que as sobreviventes não consigam deixar descendentes.

Por isso, a última etapa deste estudo consistiu em avaliar se as células que sobreviveram à TFD, e as suas descendentes, mantêm a capacidade proliferativa, e se sim se ela está aumentada ou diminuída. Para tal, realizou-se um experimento em que se utilizou um sistema que acompanha em tempo real o índice celular de uma cultura. Os resultados mostraram que, embora menor do que no grupo controle, as células sobreviventes à TFD, e talvez as suas 
descendentes, continuavam a proliferar. Por isso resolveu-se aplicar mais uma sessão de TFD a essas células, sendo o intervalo entre as duas sessões de 48 horas. Os resultados mostram que cinco dias depois da segunda sessão praticamente as células de todas as linhagens foram eliminadas. A eliminação de células tumorais após várias sessões de TFD já está bem definida. Em um estudo com camundongos utilizando AICIFt lipossomal, Bicalho e colaboradores (2013) mostraram que com três sessões de TFD, realizadas em intervalos de 72 horas, tumores de língua eram erradicados. Na clínica, a TFD é aplicada em uma sessão para lesões pré-malignas e duas sessões, com intervalo de sete dias, para lesões malignas, ou várias sessões após recidiva (VANACLOCHA et alli, 2015).

Diante dos resultados obtidos neste estudo é plausível acreditar que a $\mathrm{Fe}_{2} \mathrm{O}_{3} / \mathrm{AO} / \mathrm{P}-\mathrm{F} 127-\mathrm{AlClFt}$ é um nanomaterial promissor para ser empregado como fotossensibilizante na TFD. Para isso, sugere-se que outros estudos sejam conduzidos in vivo para reforçar a sua eficácia não só na TFD, mas também a sua eficácia na magnetoterapia, de modo que ele possa ser utilizado como uma modalidade terapêutica para irradicação de tumores sólidos. 
Com base nos resultados obtidos neste estudo conclui-se que:

- o nanomaterial $\mathrm{Fe}_{2} \mathrm{O}_{3} / \mathrm{AO} / \mathrm{P}-\mathrm{F} 127-\mathrm{AICIFt}$,quando ativado por luz LED no comprimento onda de $660 \mathrm{~nm}$, é capaz deinduzir a formação de oxigênio singleto;

- a terapia fotodinâmica mediada pelonanomaterial $\mathrm{Fe}_{2} \mathrm{O}_{3} / \mathrm{AO} / \mathrm{P}-\mathrm{F} 127-$ AICIFtelimina células das linhagens NIH/3T3, MCF-7, A431e HeLa;

- o fotossensibilizante AICIFtlivre ou adsorvido $\mathrm{aFe}_{2} \mathrm{O}_{3} / \mathrm{AO} / \mathrm{P}-\mathrm{F} 127$, ao ser incorporado pelas células das linhagens NIH/3T3, MCF-7, A431e HeLa, se deposita no citoplasma dessas células;

- a terapia fotodinâmicamediada pelo nanomaterial $\mathrm{Fe}_{2} \mathrm{O}_{3} / \mathrm{AO} / \mathrm{P}-\mathrm{F} 127-$ AICIFtinduz, preferencialmente, morte celular por necrose;

- a terapia fotodinâmica mediada pelo nanomaterial $\mathrm{Fe}_{2} \mathrm{O}_{3} / \mathrm{AO} / \mathrm{P}-\mathrm{F} 127-$ AlCIFtinduz despolarização das membranas das mitocôndrias das células da linhagem NIH-3T3;

- a terapia fotodinâmica mediada pelo nanomaterial $\mathrm{Fe}_{2} \mathrm{O}_{3} / \mathrm{AO} / \mathrm{P}-\mathrm{F} 127-$ AICIFt induz fragmentação no DNA de células das NIH-3T3, MCF-7 e A431;dependendo da concentração de AICIFt;

- as células das linhagens NIH/3T3, MCF-7, A431 e HeLadependendo da concentração de AICIFtnão sobrevivem a duas sessões de TFD mediada pelo nanomaterial $\mathrm{Fe}_{2} \mathrm{O}_{3} / \mathrm{AO} / \mathrm{P}-\mathrm{F} 127-\mathrm{AICIFt}$ 
ACS - AMERICAN CANCER SOCIETY. Cancer facts \& figures 2013. Atlanta: american cancer society; 2013.

AGOSTINIS, PATRIZIA; BERG, KRISTIAN; CENGEL, KEITH A.; FOSTER, THOMAS H.; GIROTTI, ALBERT W.; GOLLNICK, SANDRA O.; HAHN, STEPHEN M.; HAMBLIN, MICHAEL R.; JUZENIENE, ASTA; KESSEL, DAVID; KORBELIK, MLADEN; MOAN, JOHAN; MROZ, PAWEL; NOWIS, DOMINIKA; PIETTE, JACQUES; WILSON, BRIAN C.; GOLAB, JAKUB. Photodynamic therapy of cancer: an update. Cancer J. Clin.v.61, p.250281. 2011.

ALBANI, BRYAN A.; PEÑA, BRUNO; LEED, NICHOLAS A.; DE PAULA, NATALY A. B. G.; PAVANI, CHRISTIANE; BAPTISTA, MAURICIO S.; DUNBAR, KIM R.; TURRO, CLAUDIA. Marked improvement in photoinduced cell death by a new trisheteroleptic complex with dual action: singlet oxygen sensitizationand ligand dissociation. Journal of theamerican chemical society.v.136,p.17095-17101, 2014.

ANG CY; TAN SY; ZHAO Y.Recent advances in biocompatible nanocarriers for delivery of chemotherapeutic cargoes towards cancer therapy. Org. Biomol. Chem. v.12, p.4776-4806, 2014.

BAI LY, YANG XQ, AN J, ZHANG L, ZHAO K, QIN MY, FANG BY, LI C, XUAN $Y$, ZHANG XS, ZHAO YD, MA ZY.Multifunctional magnetic-hollow gold nanospheres for bimodal cancer cell imaging and photothermal therapy.Nanotechnology. v.26, n. 315701, 12pp, 2015.

BATRAKOVA, ELENA V; KABANOV, ALEXANDER V. Pluronic block copolymers: evolution of drug delivery concept from inert nanocarriers to biological response modifiers. Journal of controlled release. v.130,p.98106, setembro. 2008.

BICALHO LS1, LONGO JP, CAVALCANTI CE, SIMIONI AR, BOCCA AL, SANTOS MDE F, TEDESCO AC, AZEVEDO RB.Photodynamic Therapy Leads to Complete Remission of Tongue Tumors and Inhibits Metastases to Regional LymphNodes.Journal of Biomedical Nanotechnologyv.9, p. 811, 2013.

BHUVANESWARI R, GAN YY, SOO KC, OLIVO M. The effect of photodynamic therapy on tumorangiogenesis. Cell mol life sci.v.66, p.2275-2283, 2009.

BOLFARINI, G. C.; SIQUEIRA-MOURA, M.P.; DEMETS, G.J.; MORAIS, P.C.; TEDESCO, A.C.In vitro evaluation of combined hyperthermia and 
photodynamic effects using magnetoliposomes loaded with cucurbituril zinc phthalocyanine complex on melanoma. Journal of photochemistry and photobiology b: biology.v.115, p.1-4, 2012.

BUYTAERT, ESTHER; DEWAELE, MICHAEL; AGOSTINIS, PATRIZIA. Molecular effectors of multiple cell death pathways initiated by photodynamic therapy. Biochimica et biophysica acta. v. 1776, p. 86107, 2007.

Carré, V.; Gaud, O.; Sylvain, I.; Bourdon, O.; Spiro, M.; Blais, J.; Granet, R.; Krausz, P.; Guilloton, M.; Fungicidal properties of mesoarylglycosylporphyrins: influence of sugar substituents on photoinduced damage in the yeast Saccharomyces cerevisiae J. Photochem. PhotobiolB. v. 48, p. 57-62, 1999.

CHU, M., SHAO, Y.; PENG, J.; DAI, X.; LI, H.; WU, Q.; SHI, D. Near-infrared laser light mediated cancer therapy by photothermal effect of $\mathrm{Fe}_{3} \mathrm{O}_{4}$ magnetic nanoparticles. Biomaterials.v.34, p. 4078-4088, 2013.

COTRUVO, J.A.; STUBBE, J. Class i ribonucleotide reductases: metallocofactor assemblyand repair in vitro and in vivo. Annu. Rev. Biochem. v.80, p.733-767, 2011.

EBLEN ST.Regulation of chemoresistance via alternative messenger RNA splicing. Biochem Pharmacol. v. 83, p. 1063-72, 2012.

FAVERO, GM; BYDLOWSKI; SP. LDL RECEPTORS: ANTINEOPLASIC DRUG TARGET. Publ. UEPG Ci. Biol. Saúde, Ponta Grossa, v.14, n.1, p. 53-58, mar. 2008.

GATENBY, ROBERT A. E GILLIES, ROBERT J. Glycolysis in cancer: a potential target for therapy. The international journal of biochemistry \& cell biology.v.39, p.1358-1366, 2007.

GLENNY, A. M.;GIBSON, F.; AULD, E.;COULSON, S.; CLARKSON, J. E.; CRAIG, J. V.;EDEN, O. B.;WORTHINGTON, H. V.;PIZER, B. A survey of current practice with regard to oral care for children being treated for cancer. Eur j cancer. v.40, p.1217-24, 2004.

GUO, H.;LIU, Y.;WANG, Y.; WU, J.; YANG, X.;LI, R.;WANG, Y.;ZHANG, N. Phsensitive pullulan-based nanoparticle carrier for adriamycin to overcome 
drug-resistance of cancercells. Carbohydrate polymers.v.111, p.908917, 2014.

HANAHAN, DOUGLAS E WEINBERG, ROBERT A. Imagem de marca do cancer: the next generation. Cell.v.144, p. 646-674, 2011.

HUANG, P.; LI, Z.; LIN, J.;YANG, D.;GAO, G.;XU, C.;BAO, L.;ZHANG, C.;WANG, K.;SONG, H.;HU, H.;CUI, D.Photosensitizer-conjugated magnetic nanoparticles for in vivo simultaneous magneto fluorescent imaging and targeting therapy. Biomaterials.v.32, p. 3447 - 3458, 2011.

INSTITUTO NACIONAL DO CÂNCER INCA. RIO DE JANEIRO: INCA 2013. Disponível em: http://www.inca.gov.br/estimativa/2014/index.asp?ID=2. acesso:abril de 2015.

INSTITUTO NACIONAL DO CÂNCER INCA. RIO DE JANEIRO: INCA 2013. Disponível em: http://www.inca.gov.br/estimativa/2014/tbregioes consolidado.asp acesso: abril de 2015.

IMAM, SYED Z.; LANTZ-MCPEAK, SUSAN M.; CUEVAS, ELVIS; ROSASHERNANDEZ, HECTOR; LIACHENKO, SERGUEI; ZHANG, YONGBIN; SARKAR, SUMIT; RAMU, JAIVIJAY; ROBINSON, BONNIE L.; JONES, YVONNE; GOUGH, BOBBY; PAULE, MERLE G.; ALI, SYED F.; BINIENDA, ZBIGNIEW K. Iron oxide nanoparticles induce dopaminergic damage: in vitro pathways and in vivo imaging reveals mechanism of neuronal damage. Cellular and molecular life sciences. v. 72 , p. 983997, 2015.

ISO / TC 229 NANOTECNOLOGIAS. Acessado em março de 2015.

ISSA, MARIA CLÁUDIA ALMEIDA; MANELA-AZULAY, MÔNICA. Terapia fotodinâmica: revisão da literatura e documentação iconográfica. Anaisbrasileiros de dermatologia. v.85, p. 501-11, 2010.

JORI, GIULIO; REDDI, ELENA. The role of lipoproteins in the delivery of tumour-targeting photosensitizers. International journal of biochemistry.v.25, p. 1369-1375, outubro. 1993.

LE, THI MINH PHUC; PHAM, VAN PHUC; DANG, THI MINH LUA; LA, THI HUYEN; LE, THI HANH; LE, QUANG HUAN. Preparation of curcumin- 
loaded pluronic f127/chitosan nanoparticles for cancer therapy. Advances in natural sciences: nanoscience and nanotechnology.v.4, 2013.

MAJI, R.;DEY, N. S.;SATAPATHY, B. S.;MUKHERJEE, B.;MONDAL, S. Preparation and characterization of tamoxifen citrate loaded nanoparticles for breast cancer therapy. International journal of nanomedicine.v.9, p.3107-3118, 2014.

MAJUMDAR, P.; NOMULA R.; ZHAO, J. Activatable triplet photosensitizers: magic bullets for targeted photodynamic therapy. Journal of materials chemistryc.v.2, p.5982-5997, 2014.

MATSUMOTO, N; YOSHIKAWA, K; SHIMADA, M; KURITA, N; SATO, H; IWATA, T; HIGASHIJIMA, J; CHIKAKIYO, M; NISHI, M; KASHIHARA, H; TAKASU, C; ETO, S; TAKAHASHI, A; AKUTAGAWA, M; EMOTO. T.Effect of light irradiation by light emitting diode on colon cancer cells.Anticancer Res. v. 34, n. 9, p. 4709-4716, 2014

MOSMANN T. Rapid colorimetric assay for cellular growth and survival: application to proliferation and cytotoxicity assays.J Immunol Methods. v. 16, n. 65, p.55-63, 1983.

MUEHLMANN LA, MA BC, LONGO JP, ALMEIDA SANTOS MF, AZEVEDO RB. Aluminum-phthalocyanine chloride associated to poly(methyl vinyl ether-co-maleic anhydride) nanoparticles as a new third-generation photosensitizer for anticancer photodynamic therapy. International Journal of Nanomedicine. v.9, p.1199-1213, 2014.

MUEHLMANN, LA; RODRIGUES, MC; LONGO, JP; GARCIA, MP; PY-DANIEL, KR; VELOSO, AB; DE SOUZA, PE; DA SILVA, SW; AZEVEDO RB. Aluminium-phthalocyanine chloride nanoemulsions for anticancer photodynamic therapy: Development and in vitro activity against monolayers and spheroids of human mammary adenocarcinoma MCF-7 cells. Journal of Nanobiotechnology. v.13:36, 2015.

NUNES, S.M.T; SGUILLA, F.S.; TEDESCO, A.C. Photophysical studies of zinc phthalocyanine and chloroaluminum phthalocyanine incorporated into liposomes in the presence of additives, Brazilian Journal of Medical and Biological Research. v.37,n.2, p. 273-284, 2004.

OLIVEIRA, K.T; DE SOUZA, J.M; GOBO, N.R.S.; DE ASSIS, F.F.; BROCKSOM, T.J. Conceitos fundamentais $e$ aplicações de 
fotossensibilizadores do tipo porfirinas, clorinas e ftalocianinas em terapias fotônicas. Rev. Virtual quim.v.7,n.1 p.310-335, 2015.

ORGANIZAÇÃO MUNDIAL DA SAÚDE (OMS). Globocan 2012, Cancer incidence and mortality worldwide. Lyon, france: IARC. Disponível em http://globocan.iarc.fr/Default.aspx acesso em abril 2015.

POURCELOT, EMMANUEL; LÉNON, MARINE; MOBILIA, NICOLAS; CAHN, JEAN-YVES; ARNAUD, JOSIANE; FANCHON, ERIC; MOULIS, JEANMARC; MOSSUZ, PASCAL. Iron for proliferation of cell lines and hematopoietic progenitors: nailingdown the intracellular functional iron concentration. Biochimica et biophysica acta.v.1853,p.1596-1605, 2015.

RYTER, S. W.; KIM,H. P.; HOETZEL, A.; PARK, J. W.; NAKAHIRA, K.; WANG, $\mathrm{X}$.; CHOI, A. M. K.Mechanisms of cell death in oxidative stress. Antioxid redox signal. v.9, c.1, p.49-89, 2007.

ROSENKRANZ, ANDREY A.; JANS, DAVID A., SOBOLEV, ALEXANDER S. Targeted intracellular delivery of photosensitizers to enhance photodynamic efficiency. Immunology and cell biology.v.78, p.452-464, 2000.

ROSSI-BERGMAN, BARTIRA. A nanotecnologia: da saúde para além do determinismo tecnológico. Cienc. Cult. v.60, n. 2, São Paulo, 2008.

SUGANYA, K.S.; GOVINDARAJU, K.; KUMAR, V.G.; DHAS, T.S.; KARTHICK, V.; SINGARAVELU, G.; ELANCHEZHIYAN, M. Blue green alga mediated synthesis of gold nanoparticles and its antibacterial efficacy against gram positive organisms. Materials science and engineering. v. 47, p.351356, 2015.

TAPAJÓS, E.C.; LONGO, J.P.; SIMIONI, A.R.; LACAVA, Z.G.; SANTOS, M.F.; MORAIS, P.C.; TEDESCO, A.C.; AZEVEDO, R.B. In vitro photodynamic therapy on human oral keratinocytes cells using chloroaluminumphthalocyanine. Oral oncology.v.44, p.1073-1079, 2008.

TOMAZINI, M. V.; SOUZA, C. S.; GARCIA, S. B.; TEDESCO, A.C. Terapia fotodinâmica com ftalocianina de zinco tópica: avaliação da intensidade de fluorescência, absorção cutânea, alterações histológicas e imunohistoquímicas na pele do modelo animal. Anais brasileiros de dermatologia.v...82, p.535, 2007. 
VANACLOCHA, VICENTE; SUREDA, MANUEL; AZINOVIC, IGNACIO; REBOLLO, JOSEBA; CAÑON, ROSA; SAPENA, NIEVES SAIZ; CASES, FRANCISCO GARCÍA; BRUGAROLAS, ANTONIO. Photodynamic therapy in the treatment of brain tumours. A feasibility study. Photodiagnosis and therapy.doi:10.1016/i.pdpdt.2015.05.007. 2015.

photodynamic

KOLAROVA, $\mathrm{H}$; BAJGAR, R.; TOMANKOVA, K.; NEVRELOVA, P.; MOSINGER, J. Comparison of sensitizers by detecting reactive oxygen species after photodynamic reaction in vitro. Toxicology in vitro.v.21,p. 1287-1291, Outubro, 2007.

KOLAROVA, H; NEVRELOVA, P.; BAJGAR, R.; JIROVA, D.; KEJLOVA, K.; STRNAD, M. In vitro photodynamic therapy on melanoma cell lines with phthalocyanine. Toxicology in vitro. v.21, p. 249-253. Março. 2007.

KUMAR, VINAY; ABBAS, ABUL K.; FAUSTO, NELSON. Robbins \& Cotran patologia - bases patológicas das doenças. $7^{a}$ ed. 2005.

WEI, Z; YUAN, S; HAO, J; FANG, X. Mechanism of inhibition of P-glycoprotein mediated efflux by Pluronic P123/F127 block copolymers: relationship between copolymer concentration and inhibitory activity. Eur J Pharm Biopharm. v. 83, n. 2, p. 266-274, 2013.

WEINBERG, R.A. The Biology of Cancer. Garland Science. $2^{\circ}$ Ed. 796, 2014.

WHO. Cancer. Fact sheet n²97. Disponível em: < http://www.who.int/mediacentre/factsheets/fs297/en/>acesso em abril de 2015.

WOJTONISZAK, M.; Rogin'ska, D.; Machalin'ski, B.; Drozdzik, M.; Mijowska, E. Graphene oxide functionalized with methylene blue and its performance in singlet oxygen generation. Materials research bulletin. v.48, p.26362639, 2013.

Wu, X; Alberico, S; Saidu, E; Rahman Khan, S; Zheng, S; Romero, R; Sik Chae, H; Li, S; Mochizuki, A; Anders, J. Organic light emitting diode improves diabetic cutaneous wound healing in rats. Wound Repair Regen. v. 23, n. 1, p.104-14, 2015.

YHEE JY, SONG S, LEE SJ, PARK SG, KIM KS, KIM MG, SON S, KOO H, KWON IC, JEONG JH, JEONG SY, KIM SH, KIM K.Cancer-targeted 
MDR-1 siRNA delivery using self-cross-linked glycol chitosan nanoparticles to overcome drug resistance.J Control Release. v 28;n. 198, p.1-9, 2015.

ZHANG, W.;GUO, Z.; HUANG, D.; LIU, Z.;GUO, X.;ZHONG, H.Synergistic effect of chemo-photothermal therapy using pegylated graphene oxide. Biomaterials.v.32, p.8555 e 8561, 2011.

ZEE, J. VAN DER. Heating the patient: a promising approach? Annals of oncology. C. 13, v.8, p.173-1184, 2002.

ZIELICHOWSKA, A; SACZKO, J.; GARBIEC, A.; DUBIŃSKA-MAGIERA, M.; ROSSOWSKA, J.; SUROWIAK, P.; CHOROMAŃSKA, A.; DACZEWSKA, M.; KULBACKA, J.; LAGE, H. The photodynamic effect of far-red range phthalocyanines (alpc and $p c$ green) supported by electropermeabilization in human gastric adenocarcinoma cells of sensitive and resistant type. Biomedicine \& pharmacotherapy.v.69, p.145-152, 2015. 